Федеральное государственное бюджетное образовательное учреждение

$$
\text { высшего образования }
$$

«КУБАНСКИЙ ГОСУДАРСТВЕННЫЙ УНИВЕРСИТЕТ»

(ФГБОУ ВО «КубГУ»)

Факультет педагогики, психологии и коммуникативистики

Игнатович В.К., Бондарев П.Б., Игнатович С.С., Курочкина В.Е.

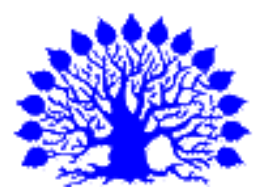

ОСНОВЫ МЕТОДОЛОГИИ И ТЕХНОЛОГИЯ ПРОЕКТИРОВАНИЯ ИНДИВИДУАЛЬНЫХ

ОБРАЗОВАТЕЛЬНЫХ РЕЗУЛЬТАТОВ УЧАЩИХСЯ В

СИСТЕМЕ ДОПОЛНИТЕЛЬНОГО ОБРАЗОВАНИЯ ДЕТЕЙ

Монография

Краснодар 2020 
DOI: $10.17748 / 978-5-906302-25-0-2020-1-200$

УДК 373.5(076.5)

ББК 74.6 Я 7

И 602

Рецензенты: Доктор педагогических наук, профессор

\section{В.С. Елагина}

Кандидат педагогических наук, доцент

\section{Е.В. Гелясина}

Игнатович В.К., Бондарев П.Б., Игнатович С.С., Курочкина В.Е.. Основы методологии и технология проектирования индивидуальных образовательных результатов учащихся в системе дополнительного образования детей: монография. // Краснодар: Изд-во: КУБ ГУ - КМАПППКС,- 2020. - 200 с.

ISBN 978-5-906302-25-0

Исследование проведено при финансовой поддержке Российского фонда фундаментальных исследований (проект № 18-013-00308 A «Основы методологии и технология проектирования индивидуальных образовательных результатов учащихся в системе дополнительного образования детей»)

В монографии представлены результаты научного исследования, посвященного проблеме теоретико-методологического и технологического обоснования условий становления субъекта построения индивидуальной образовательной траектории. Цель проведенного исследования состояла в разработке и обосновании модели проектирования индивидуальных образовательных результатов детей разного возраста в системе дополнительного образования как нового вида образовательной деятельности, осуществляемой в субъектсубъектном взаимодействии педагогов и учащихся. Представлены результаты анализа состояния исследуемой проблемы в 
науке и практике образования. Обосновано понятие индивидуального образовательного результата, охарактеризованы пути их формирования в онтогенезе. Разработана и описана теоретическая модель проектирования индивидуальных образовательных результатов в процессе дополнительного образования, даны характеристики субъектности педагогов и учащихся и возможностей их целенаправленного формирования. Охарактеризованы педагогические условия, обеспечивающие эффективность этой деятельности. Даны методические рекомендации по организации свободных социальных проб учащихся как субъектов проектирования собственных образовательных результатов. Описаны компоненты технологии проектирования и мониторинга индивидуальных образовательных результатов учащихся в процессе дополнительного образования.

ISBN 978-5-906302-25-0

(C) КубГУ, 2020

(C) Авторский коллектив, 2020

(C) Издательство КМАПППКС, 2020 


\section{ВВЕДЕНИЕ}

Проектирование и оценка индивидуальных образовательных результатов учащихся остается одним из наименее разработанных аспектов исследований, связанных с индивидуализацией современного образования. Разрыв между пониманием сущности этого процесса как обретения каждым учеником возможности выстраивания индивидуальной образовательной траектории, приводящей его к максимуму реализации собственных творческих возможностей, и взглядами на образовательные результаты ученика как на усвоенные им нормы и способы действий сохраняется и на теоретико-методологическом и на практическом уровнях. Характеризуя идею индивидуализации образования, современные исследователи подчеркивают, что «можно построить школу на совершенно других педагогических принципах, создав каждому ребенку широкий индивидуальный выбор того, чему, как и у кого учиться, самостоятельно проектируя и контролируя свое образование» [99, с. 29]. В работах А.Г. Асмолова, А.Б. Воронцова, В.М. Гребенниковой, Т.М. Ковалевой, В.Т. Кудрявцева, В.И. Слободчикова, Б.Д. Эльконина и др., во многом основанных на идеях развивающего обучения В. В. Давыдова - Д. Б. Эльконина, подчеркивается, что индивидуальная образовательная траектория ученика складывается из событий, в которых он, выступая в роли субъекта освоения Культуры, приобретал новый для себя опыт в широком спектре субъект-субъектных взаимодействий с другими людьми. Движущей силой этого процесса выступает, в первую очередь, творческая активность самого субъекта, направленная на освоение проблематизированных культурных содержаний окружающего мира. Однако именно эта первичность субъекта не учитывается, когда речь заходит о целеполагании и оценке достигаемых им образовательных результатов, поскольку первичными в 
данном случае выступают требования к этим результатам, содержащиеся в образовательных программах. Эти требования являются общими для всех учащихся, что, в свою очередь, обусловливает единообразие образовательных результатов. Данное обстоятельство существенно осложняет процесс институционализации образовательных систем, базирующихся на принципе индивидуализации образования.

Проблема, которую необходимо решить для преодоления данного противоречия, состоит в теоретикометодологическом и технологическом обосновании условий становления субъекта построения индивидуальной образовательной траектории, способного осознанно проектировать индивидуальные образовательные результаты как необходимые в социальной ситуации его развития культурные средства достижения значимых целей личностного и профессионального самоопределения. Она возникает в контексте глобальных изменений окружающего мира, связанных с увеличением его многообразия, поликультурности, возрастанием социокультурной неопределенности и общей ориентацией перспектив его дальнейшего развития в будущее, в котором человечеством могут быть найдены ответы на актуальные вызовы современности. Как следствие этого возникает общая тенденция отказа от использования единых моделей взаимоотношений между людьми и норм социального поведения в пользу освоения новых возможностей жизнеустройства и самореализации человека в обществе. В данной ситуации развитие индивидуальности каждого человека и построение им индивидуальной образовательной траектории, приводящей к освоению латентных возможностей его личности совершить «бросок в будущее», становится наиболее эффективной стратегией жизни [83]. 
Для решения данной проблемы необходимо дать онтологическое описание процесса построения индивидуальной образовательной траектории как системно организованной деятельности субъекта саморазвития, в которой реализуются его базовые культурные потребности в творческой самореализации и самоопределении.

Данная задача требует решения на междисциплинарном уровне. Так, с точки зрения философии построение индивидуальной образовательной траектории необходимо рассмотреть как форму отношения человека к окружающему миру и самому себе, отвечающую нормам и ценностям становящегося постиндустриального общества и характеризующуюся его ориентацией на преобразование действительности и максимальное раскрытие творческих возможностей Культуры в индивидуальной биографии.

В аспекте психологии и психологической антропологии индивидуализацию образования необходимо обосновать с точки зрения становления внутренней позиции человека как субъекта жизни и «автора своей судьбы», раскрыть взаимосвязь осуществления им индивидуальной образовательной траектории и формирования новых содержаний его внутреннего мира и сознания.

Социологический аспект данной задачи связан с рассмотрением построения субъектом индивидуальной образовательной траектории как инновационной социальной практики, характеризующейся трансформацией традиционных образовательных институтов и смещением доминанты на самого субъекта с его образовательными потребностями и способностями удовлетворять их с помощью разнообразных образовательных ресурсов открытой социокультурной и информационной среды.

С точки зрения педагогики данная задача предполагает создание методологии и теории проектирования педагогических (образовательных) систем, ориентирован- 
ных на развитие индивидуальности учащихся посредством организации их свободной творческой деятельности, направленной на освоение ценностей и культурных содержаний окружающей среды. В данной системе проектирование индивидуальных образовательных результатов должно выступать системообразующим компонентом. Необходимо установить и описать его связи с другими компонентами системы, построить на этой основе теоретическую модель индивидуализированного образовательного процесса, выявить и обосновать эффективные средства и педагогические условия становления непрерывной образовательной траектории как авторского проекта самого ученика.

В нашем исследовании проблемное поле этой задачи было спроецировано в сферу специфических возможностей дополнительного образования как особой образовательной системы, характеризующейся ориентацией на индивидуальные образовательные потребности ребенка и вариативностью возможностей их удовлетворения в процессе развития различных видов творческой деятельности. В этом смысле описанная задача предполагает обоснование индивидуального образовательного результата как феномена особой образовательной среды, обладающей характеристиками вариативности и избыточности возможностей построения субъектом индивидуальной образовательной траектории и более высокой (по сравнению с общеобразовательной школой) степенью социокультурной неопределенности ситуации ее практического осуществления субъектом.

Научная новизна представленного в настоящей монографии подхода к решению данной проблемы состоит в обосновании проектирования индивидуальных образовательных результатов как особой деятельности субъекта, выступающей в роли базового условия его самостоятельного продвижения по индивидуальной образовательной 
траектории и достижения им значимых целей личностного и профессионального самоопределения. Эта деятельность осуществляется субъектом (учеником) на высоком уровне образовательной самостоятельности и при активном взаимодействии с другими субъектами образовательного процесса, выстраивая с ними особые субъектсубъектные отношения, отсутствующие в обычных моделях образовательных систем. Такой подход существенно отличается от традиционного взгляда на образовательный результат как на внешний по отношению к самому учащемуся атрибут образовательной программы, проектируемый на основании усредненных представлений о средствах, необходимых человеку для дальнейшей социализации в определенных социокультурных условиях. В предложенном подходе, базирующемся на положениях культурно-исторической концепции Л.С. Выготского, образовательный результат мыслится как атрибут субъективной реальности самого ученика, феномен его сознания, порождаемый в событийной общности с другими людьми (в первую очередь, с педагогами) обладающий индивидуальным значением для самого субъекта. Поэтому понятие индивидуального образовательного результата в нашем случае несет смысловую нагрузку индивидуально проектируемого средства определения субъектом своего отношения к явлениям окружающего мира и реализации своих индивидуальных образовательных потребностей высшего порядка (потребности в творческой самореализации, самоактуализации, самоопределении). Это обоснование возможно на основе единства и взаимодополняемости культурно-исторического, гуманистического и компетентностного подходов к решению данной проблемы, с чем связана новизна методологической базы исследования.

В настоящей монографии представлены результаты исследования, в котором авторы предприняли попытку 
научного обоснования этого подхода к решению обозначенной проблемы. В первой главе на междисциплинарном уровне охарактеризованы предпосылки возникновения исследуемой проблемы в системе современных представлений об индивидуализации образования. Раскрыты сущность и содержание понятия «индивидуальный образовательный результат», выявлены и охарактеризованы особенности проектирования индивидуальных образовательных результатов на разных этапах возрастного развития ребенка. Дан сравнительный анализ образовательных результатов, достигаемых учащимися в системах общего и дополнительного образования, обоснованы особые возможности индивидуализации образовательного процесса в специфических условиях процесса дополнительного образования.

Во второй главе приведены результаты исследования современных практик полагания и оценки индивидуальных образовательных результатов учащихся, показаны их внутренние противоречия, выступающие препятствиями индивидуализации образовательного процесса. Дана общая характеристика проектирования индивидуальных образовательных результатов как особого вида образовательной деятельности, осуществляемой в субъектсубъектном взаимодействии учащихся и педагогов дополнительного образования. Даны базовые характеристики их субъектности учащихся и педагогов, реализуемой в процессе этой совместной деятельности, показаны возможности ее развития в процессе специально организованного обучения.

Третья глава посвящена описанию методических и технологических аспектов проектирования индивидуальных образовательных результатов учащихся в процессе дополнительного образования. Даны описания педагогических условий, необходимых для обеспечения эффективности этой деятельности. Раскрыты теоретические осно- 
вания и даны методические рекомендации по организации свободных социальных проб учащихся как эффективного средства формирования их готовности к субъектному участию в проектировании собственных образовательных результатов. Представлено методическое описание технологии проектирования индивидуальных образовательных результатов учащихся в процессе дополнительного образования. Раскрыты подходы к проектированию подсистем оценки и мониторинга этих результатов как инструментов управления развитием учреждения дополнительного образования.

Авторы выражают благодарность педагогическому коллективу Центра дополнительного образования «Хоста» г. Сочи, на базе которого осуществлялись пилотные исследования и экспериментальная апробация полученных результатов. 


\section{1. Теоретико-методологические основания проблемы проектирования индивидуальных образовательных результатов учащихся в процессе дополнительного образования}

1.1. Философские, культурно-исторические и практико-педагогические предпосылки проблемы проектирования индивидуальных образовательных результатов в системе дополнительного образования детей

Человек живет и действует среди других людей, иначе он не сможет полноценно реализовать ни самого себя, ни свою социальную роль, но должен ли он бесследно раствориться среди «связанных одной целью, скованных одной цепью», в мире, где «первые» так «на последних похожи»? Диалектика обобществленности и автономности личности задает общие философские проблемы и определяет противоречия в формировании человеческой индивидуальности. Обособленность индивида представляет собой необходимую предпосылку для развития способности человека к проявлению самостоятельности, ответственности, инициативности.

Современная стратегия развития системы дополнительного образования детей в России предполагает опору на принцип индивидуализации, суть которого, по мнению авторов «Рабочей концепции одаренности» (под ред. Д.Б. Богоявленской) состоит в том, что цели, содержание и процесс обучения должны как можно более полно учитывать индивидуальные и типологические особенности учащихся. Реализация этого принципа особенно важна при обучении одарённых детей, у которых индивидуальные различия выражены в яркой и уникальной форме. Для реализации данного принципа, считают авторы концепции, лучше подходит система дополни- 
тельного образования, предназначенная для «удовлетворения постоянно изменяющихся индивидуальных социокультурных и образовательных потребностей одарённых детей» [13, с. 64]. В Федеральном законе № 273-Ф3 «Об образовании в Российской Федерации» от 29 декабря 2012 г. дополнительное образование определяется как «сфера вариативного содержания образования, развития личности в соответствии с индивидуальными образовательными потребностями, способностями, интересами, особенностями» [92]. Таким образом, индивидуализация относится к приоритетным принципам, лежащим в основании процесса модернизации системы дополнительного образования детей, она предполагает создание комплекса условий, содействующих раскрытию уникальных способностей индивидуальности учащихся.

Осмысление социально-культурного феномена индивидуализации образования в культуре имеет, прежде всего, историко-философское измерение. Анализ моделей взаимодействия человека и общества присутствует в философском мировоззрении как отдельных мыслителей, так и целых исторических эпох. Представители философского индивидуализма разных исторических эпох всегда рассматривали общество как форму совместного существования автономных, свободных и самостоятельных субъектов, своеобразную со-деятельность отдельных людей, объединённых общими для них природными и социокультурными условиями жизни.

Появление индивидуализма традиционно связывают с античным гуманизмом как формой философского мировоззрения. Именно в нем находят свое первоначальное обоснование идеи самоценности человека, его свободы, творчества, стремления к саморазвитию как ценности. Антропоцентрическая философия античности ищет ответы не только на вопрос об онтологии этих ценностей (что 
есть?), но и об их распространении (как этого достичь?). В Античной философии наиболее глубоко проблематику индивидуализации образования осмыслил Сократ. Он исходил из признания приоритетности в деле воспитания внутренних факторов (наследственности и воли) перед внешними (влияние среды и других людей). Сократ призывает к самопознанию как единственно возможному для него пути совершенствования.

В эпоху Возрождения человек также ищет опору для своего существования и развития в себе самом. Возрожденческий гуманизм объединил ценности этики творческого начала с выраженным эгоцентризмом, определенной небрежностью к обществу и его потребностям. Человек эпохи Возрождения почувствовал, опробовал социальную автономию, но он еще не в состоянии связать ее с обществом, культурой, найти единство личного и общественного благополучия.

В эпоху Просвещения принцип индивидуализации приобретает свое социокультурное и даже правовое основание. Политико-правовой аспект гуманизма закрепляют Декларации прав человека (принятые в конце XVIII в. в революционных Франции и США), которые признают за индивидом частные права, которые государство не имеет права нарушать (доступ граждан к необходимому минимуму жизненных благ, осуждение казней и негуманных судебных процессов, свободу инакомыслия и вероисповедания, неприкосновенность частной собственности и жилья, и т.д.). В основе индивидуализма лежит признание абсолютной ценности, неповторимости, уникальности личности, неприкосновенность личных свобод. Однако индивидуализм не отменяет законы, нормы морали, поведение индивидуальности правовое, если оно не унижает достоинство и честь других людей. Основная трудность состоит в том, чтобы найти способы примирения индиви- 
дуальных свобод личности с общественными потребностями и идеалами. Решение проблемы индивидуализма переходит в область философии права (теория общественного договора Ж.Ж. Руссо, философско-правовые модели И. Канта и других представителей немецкой классической философии).

На рубеже XIX и XX вв. наиболее ярким критиком распространённой схоластической модели образования выступает основатель построенной на принципе индивидуализма прагматической философии Джон Дьюи. Будучи педагогом по профессии, он фиксирует проблемы современной ему школы: пренебрежение к учащимся, отрыв содержания образования от жизни, слабую результативность и низкую эффективность процесса обучения. Цель образования, по его мнению, должна строиться от «самовыявления» данных ребенку от рождения инстинктов и склонностей. Дьюи предлагает восстановить связь школы с жизнью, обеспечить развитие активности детей в учебном процессе, формировать интерес как основной мотив обучения и др. В своих трудах по философии образования Дж. Дьюи сформулировал положение о том, что личный опыт ребенка составляет основу процесса обучения. Это непрекращающийся процесс, «ведущий к неподдающимся определению целям». Вывод, который делает Дж. Дьюи в книге «Демократия и образование» (1916), однозначен: для развития учащихся «унция опыта стоит больше, чем тонна теории» [28, с. 164].

Образование в педагогической концепции Дьюи происходит «внутри» ученика, что в большинстве случаев оказывается неподконтрольно педагогам. Успех должен сопутствовать личности учащегося в каждом ее опыте. Педагог призван помочь каждому ребенку поставить свои собственные, индивидуальные цели. По мнению Дж. Дьюи, содержание образования должно определяться учащими- 
ся. Поэтому заранее составленные школьные программы не нужны, вредно деление обучения на предметы, это мешает интеграции учения и образованию личных понятий. Нужно совместное с учащимися проектирование индивидуальных образовательных программ. Прагматисты отказываются от навязывания образования извне, от использования методов и содержания обучения, оторванных, от жизни, заранее подготовленных учебных материалов.

B XX в. основным направлением, осуществляющим философское обоснование индивидуализации обучения, становится экзистенциализм. Основным положением, на котором строится философия экзистенциализма, является «существование» человека, как самобытного «я», предшествующего сущности человека и творящего ее. Экзистенциалисты отмечают деформацию личности в современном мире, ее отчуждение, утерю своеобразия и т.п. Выход из этого положения они видят в том, что индивид должен творить себя сам. Важнейшая роль в сохранении целостности и уникальности личности отводится системе образования. Ее цель состоит в обеспечении ребенка средствами и способами созидания самого себя как индивидуальности.

Основная философская посылка экзистенциализма все люди и все дети уникальны. Субъективная и индивидуалистическая направленность образования определяет роль и положение в педагогической системе педагога. Он должен полагаться на принятие личности детей и свою интуицию, на свое «я». Ученик будет конструировать окружающую среду и определять смыслы явлений в меру своих способностей. Экзистенциализм предлагает обеспечить в процессе обучения свободную атмосферу, предоставить широкие возможности для экспериментирования, осуществления выбора, освобождения от стереотипов и догм. Особое внимание экзистенциалисты обращают на 
необходимость организации успешной коммуникации между учащимися. Образовательный процесс происходит в группе, в которой каждая личность всеми признавалась как свободная и уникальная самоценность.

Таким образом, историко-философский анализ показывает, что реализация принципа индивидуализации обучения предполагает осуществление принципиально иной, несхоластической направленности образования, ориентированной на достижение уникальной результативности в развитии каждой личности. Каждый ученик должен получить возможность построить собственное содержание образования, освоить его в индивидуальном темпе и на выбранном уровне сложности, т.е. разработать и реализовать индивидуальную траекторию обучения. Такие условия изначально проще создавать в системе дополнительного образования где каждому ребенку предоставляется возможность свободного выбора образовательной области, профиля программ, времени их освоения, включения в разнообразные виды деятельности с учетом их индивидуальных склонностей.

Процесс индивидуализации образования должен быть обеспечен путем создания условий для самостоятельного выбора учащимися дополнительных образовательных услуг, самостоятельного определения тем и направлений творческой, исследовательской и проектной деятельности. Индивидуально-личностная основа деятельности учреждений дополнительного образования детей позволяет удовлетворять запросы конкретных детей, используя потенциал их свободного времени. В результате обеспечивается педагогическое содействие становлению самостоятельности и субъектности обучающихся в учебной и практической деятельности, формирование интереса, развитие их мышления. 
В исследовании В.П. Бедерхановой были выделены следующие принципы индивидуализации образования: «свободы - как возможности для учащихся реализовать свой внутренний потенциал в соответствии с собственной волей и потребностями в саморазвитии; свободы выбора как право ребенка реализовывать свою субъектность через самоопределение в принятии решений; использования мотивационных ресурсов образования - как приоритет развития внутренних побудителей деятельности учащихся перед внешними стимулами; отказа от всех форм манипуляции ребенком, в том числе от наказаний и отметок; развития опыта как средства личностного роста и включения ребенка в существующую культуру; индивидуального целеполагания - как проектирование учениками целей в образовательной деятельности» $[10$, с. 47].

Принцип индивидуализации образования разрушает представления о цели образования как формировании знаний, умений и навыков. Индивидуализация образования - это стратегическая программа качественного обновления образовательного процесса на всех его ступенях. Опыт развития образования показывает важность «естественного вплетения» принципа индивидуализации в целостный педагогический процесс на его организационном и содержательном уровнях.

В педагогической науке и современной практике образования проблема индивидуализации решается в нескольких различных вариантах. Одна из наиболее известных стратегий связана с проектированием вариативных образовательных сред, позволяющих ребенку самостоятельно выбирать виды и содержание своих занятий, объекты приложения творческих сил. На этой стратегии, в частности, построена педагогическая система М. Монтессори. Другой подход к решению этой проблемы связан со становлением института тьюторства как особого ви- 
да педагогического сопровождения, представленный, в частности, в работах Е.А. Александровой [2] и Т.М. Ковалевой [40]. Третий путь связан с проектированием событийных форматов образовательного процесса, где именно со-бытийность жизненного уклада школы выступает главным источником индивидуального развития каждого ученика (Н.Б. Крылова [51], А.Н. Тубельский [91]).

В современных исследованиях эти базовые направления получают свое дальнейшее развитие в частных, прикладных аспектах: обеспечения преемственности ступеней образования [19]; повышение эффективности использования новых образовательных ресурсов [71]; развитие образования взрослых людей [82] и др.

В то же время развитие представлений об индивидуализации образования не имеет сегодня выраженных точек пересечения с проблемами проектирования и оценки образовательных результатов учащихся. Обращаясь к истории вопроса, можно утверждать, что существовавшие в прежние годы методы оценивания уровней личностного развития, основанные на выделении определенных наборов личностных качеств, перечень которых носил достаточно субъективный характер (В.С. Ильин, А.И. Кочетов и др.), мало соответствуют представлениям об образовательных результатах, заложенных во внедряемых сегодня ФГОС. На протяжении последних десятилетий формировались новые подходы к интерпретации этого понятия. Можно утверждать, что общей рамкой такой интерпретации становятся способности самого ребенка к творческому преобразованию окружающего мира и саморазвитию, которые он сам обретает в образовательном процессе.

Несколько иное толкование того, что есть образовательный результат, представлено в разработке авторского коллектива под руководством В.В. Серикова. Образовательные результаты, определяемые как «достижения 
учащихся», здесь предлагается оценивать по критериям, характеризующим: учебные достижения учащихся (исходное состояние, динамика успешности, уровень самостоятельности и продуктивности учащихся в организуемой учителями учебной деятельности); их ответственное отношение к социальным обязанностям (уровень мотивации учения, общественное поведение, самостоятельность в организации собственной жизнедеятельности, включающая дисциплину, порядок и самообслуживание, нравственные качества по особому перечню); а также их общекультурное развитие [73].

Еще один подход к пониманию сущности результатов образования был предложен Н.В. Кузьминой, в чьей концепция под этими результатами понимается готовность ученика к переходу в последующую образовательную систему. Далее этот подход был последовательно развит в работах А.А. Остапенко [72].

В современных исследованиях изменение подходов к пониманию образовательных результатов прослеживается и в ходе сравнения требований к ним со стороны Федеральных государственных образовательных стандартов. Так, в работе Е.Н. Симкиной и И.А. Рудаковой [87] отмечается, что с переходом на ФГОС дошкольного образования смысловая характеристика в понимании образовательных результатов ребенка-дошкольника смещается от описания требуемых интегративных личностных качеств (физически развитый, любознательный, активный, эмоционально отзывчивый, овладевший средствами общения и т.д.) к описанию социальных и психологических характеристик возможных достижений ребенка (проявляет инициативность и самостоятельность; уверен в своих силах, открыт внешнему миру; обладает развитым воображением; проявляет творческие способности; способен к волевым усилиям и т.д.). 
В другом случае образовательные результаты ступени дошкольного образования фактически отождествляются с центральными психическими новообразованиями, отвечающими проживаемому возрасту - творческое воображение, способность видеть целое прежде отдельных частей, способность видеть и оценивать себя глазами другого человека и т.д. [54].

В идеологии, задаваемой ФГОС общего образования, возникают и новые обобщенные трактовки образовательных результатов, таких как формирование у учащихся «общепредметных мировоззренческих идей», к числу которых авторы исследований, в частности, относят «познаваемость мира; единство «живой» и «неживой» природы; охрана природы и рациональное природопользование; экологическая безопасность; ценность жизни и здоровья т.д.». При этом само по себе овладение данными общепредметными идеями на предметном уровне успешно трансформируется в достаточно устоявшиеся в педагогике представления об «освоенных учащимися элементах социального опыта», которые далее разворачиваются как «знания, умения и навыки, опыт решения проблем и опыт творческой деятельности» [98].

В то же время в работах, отражающих идеологию новых ФГОС, новые методологические подходы к пониманию сущности образовательного результата как собственного достижения ученика зачастую не прослеживаются. Вместо этого по-прежнему эксплуатируются представления об «уровне развитости личностных качеств обучающихся», при этом качественные характеристики этих уровней остаются за пределами внимания авторов

Таким образом, можно утверждать, что в современных исследованиях проблемы обоснования сущности понятия «образовательный результат», во-первых, мало разработан собственно контекст индивидуализации обра- 
зования, в котором может развиваться идея индивидуальных образовательных результатов учащихся как их достижений в процессе освоения индивидуальной образовательной траектории. Во-вторых, все еще недостаточно четко разведены традиционный «знаниевый» и компетентностный подходы к пониманию сущности данного феномена. И, в-третьих, практически отсутствуют исследования, в которых образовательные результаты были бы обоснованы как предмет осознанного проектирования самим учеником, выступающим в этом случае субъектом построения своей индивидуальной образовательной траектории.

1.2. Индивидуальный образовательный результат как объект исследования

Представления (как укорененные в общественном сознании, так и становящиеся в процессе инновационного развития) о том, что именно должно становиться результатом образовательного процесса, выступают системообразующим началом проектирования любых образовательных систем. На эти представления оказывают влияние множество факторов и контекстов, в которых складывается смысловая картина образовательной реальности. В этой связи невозможно выделить «единственно верное» понимание сущности образовательного результата как педагогического и социокультурного феномена. В отечественной и зарубежной науке представлены разные концепции полагания и оценки образовательных результатов учащихся. Сложность их анализа во многом связана с тем, что довольно часто исследователи не обращают пристального внимания на саму проблему определения культурной сущности этого феномена, ограничиваясь общими 
суждениями об «уровнях усвоения образовательных программ». Между тем такой поверхностный способ понимания данного феномена служит важным препятствием перехода к новым моделям образования, отвечающим требованиям динамично меняющейся действительности.

В особой степени это относится к реализации такого тренда образовательной политики, как индивидуализация образования. Несмотря на очень большое количество работ по этой проблематике, ключевое понятие «индивидуальный образовательный результат» крайне редко рассматривается исследователями как новое, социально проектируемое явление. Абсолютное большинство современных исследований сфокусировано на проблемах проектирования индивидуальных образовательных траекторий и индивидуальных образовательных программ (маршрутов) учащихся разного возраста в различных образовательных системах. При этом результаты, достигаемые учащимися в процессе осуществления этих траекторий и маршрутов, зачастую описываются либо в традиционной логике планирования и оценки продвижения учащихся в учебном материале, либо носят обобщенный характер, не дающий представления о конкретных шагах образовательного продвижения самих учащихся к максимуму раскрытия собственных творческих возможностей.

В нашем исследовании мы предприняли анализ литературы данного вопроса, стремясь выделить основные подходы и способы понимания образовательных результатов как собственных достижений учащихся в процессе осуществления ими индивидуальной образовательной траекторий. Нам удалось получить следующие важные данные, характеризующие современное состояние изучаемой проблемы.

Одной из «стержневых» идей, лежащих в основании данного направления исследований, выступает идея раз- 
вития ученика как субъекта образовательной деятельности, к чьей компетенции относится не просто усвоение учебного материала, а целеполагание самого себя в процессе выстраивания индивидуальной образовательной траектории. Эта идея развивается прежде всего в фундаментальном направлении [42], однако в последнее время стали появляться многочисленные прикладные исследования, авторы которых рассматривают становление учащегося как субъекта самоопределения в различных педагогических системах, в частности, в системе дополнительного образования детей [88;77].

Характерно, что в педагогических теориях и концепциях, не основанных на представлении об ученике именно как о субъекте его образовательного продвижения, понятие «образовательный результат», как правило, заменяется далеко не тождественными понятиями «результаты образовательного процесса» и «результаты педагогической деятельности». В обоих случаях речь идет об изменениях, происходящих в сознании (мышлении) учащихся. Так, в междисциплинарном словаре по педагогике дается следующее определение результата образовательного процесса: «Изменения в знаниях, способностях, отношениях, ценностных ориентациях, физическом состоянии учащихся и воспитанников, произошедшие в ходе пед. процесса» [44, с. 289]. Вполне понятно, что речь идет именно о тех целесообразных изменениях, которые «запланированы» и достигнуты педагогом в соответствии с действующими нормативно-правовыми основаниями его деятельности и его собственными представлениями о целях обучения и воспитания. Учащийся как субъект этого процесса в данном случае не проявлен.

В свою очередь, результаты педагогической деятельности представляют собой более широкий спектр изменений, в числе которых изменения, происходящие в 
личности учащихся и воспитанников как следствие обретаемого ими личностного опыта, рядоположены таким позициям, как качество организации педагогического процесса, профессиональные достижения самого педагога и динамика его профессионального роста. При этом результаты, «обеспеченные» деятельностью непосредственно педагога соотносятся с результатами самих учащихся, к которым И.А. Колесникова и Е.В. Титова относят их достижения в осваиваемой деятельности в виде успехов и конкретных продуктов, а также личностные проявления, их динамику, обогащение личного опыта и т.д. [45].

Следует отметить, что и в этом случае позиция учащегося как субъекта определения и достижения требуемых образовательных результатов фактически не представлена, поскольку все эти результаты «запрограммированы» педагогом и фактически совпадают (даже на уровне используемых авторами формулировок) с результатами его собственной педагогической деятельности. (Об этой тотальной запрограммированности в свое время иронично отозвался В.П. Зинченко: «Образованию пора перестать уподобляться гоголевскому Ноздреву: “До леса - мое, лес мой, за лесом тоже мое...” В человеке далеко не все формируется посредством образования» [30, с. 18].)

Картина существенно изменяется при переходе к концепции индивидуализации образовательного процесса, в которой, как было сказано, субъектность ученика имеет первостепенное значение. Для характеристики этой субъектности используются такие понятия, как самостоятельность, инициативность, ответственность, свобода, самоопределение и т.п. Так, например, в работе Т.М. Ковалевой и Т.В. Якубовской отмечается: «Принцип индивидуализации обсуждается как оборотная сторона социализации, как процесс накопления человеком особого уникального опыта, творческого потенциала, самостоя- 
тельности, свободы и ответственности» [42]. Нетрудно заметить, что основой такого видения сущности индивидуализации выступает предложенный В.В. Давыдовым и его учениками диалектический подход к пониманию индивидуальности. Индивидуальность в этой системе взглядов это «не только результат, но и сам процесс развития индивида, это неповторимое своеобразие индивида, осуществляющего свою жизнедеятельность в качестве субъекта общественно-исторического развития» $[95$, с. 24]. Однако, если авторы теорий развивающего и проблемного обучения рассматривали ученика, в основном, как субъекта учебной деятельности и в этой связи интерпретировали результаты обучения прежде всего как усвоенные способы учебных действий, лежащих в основе познавательной самостоятельности, то современные исследователи рассматривают эти феномены в более широком контексте: как самостоятельное продвижение ребенка по индивидуальной образовательной траектории, проходящей через различные учебные, социальные и культурные практики, в ходе которого им решаются «задачина-смысл» (Е.А. Александрова, В.М. Гребенникова, Н.Б. Крылова, Т.М. Ковалева, В.Т. Кудрявцев и др.).

В то же время нужно признать, что сама по себе декларация идеи индивидуализации образования как выстраивания индивидуальной образовательной траектории ребенка еще не достаточна для обоснования индивидуального образовательного результата как феномена новой образовательной реальности. Во многих исследованиях, авторы, в разных аспектах рассматривающие вопросы проектирования и осуществления индивидуальных образовательных траекторий учащихся, при описании результатов используют формулировки, в большей степени отражающие их общее, а не индивидуальное значение. Так, например, Н.А. Лабунская в своей типологии индивиду- 
альных образовательных маршрутов студентов приводит формулировки, вполне однозначно отражающие предполагаемые результаты их реализации: выделение конкретных предметных областей как областей более активного внимания; конкретизированная линия знаний - стать образованным человеком; совершенствование знаний, умений в будущей профессиональной деятельности; стремление овладеть предметной областью преподавания и передать знания учащимся; получение определенных результатов в интересующей научной области [56]. Нетрудно заметить, что за этими формулировками недвусмысленно читается понимание индивидуальности как конкретизации общего в единичном, как «подробности» воспроизводства этого общего в конкретной ситуации конкретного индивида. Да, существует некий общий объем знаний, предназначенных для всех, но индивид может выбрать из этого объема то, что в наибольшей степени соответствует его образовательной ситуации, включая интересы, предпочтения, жизненные и профессиональные планы и т.д. Если соотнести это обстоятельство с утверждением «...наличие у индивида некоторого набора неповторимых качеств (неповторимых по своим проявлениям, но по своей сути присущих и всем остальным индивидам) данного индивида индивидуальностью» $[95$, с. 22], которое с позиций В.В. Давыдова и других представителей его научной школы характеризует именно эмпирический подход к пониманию индивидуальности, становится ясным, что в данном случае результаты осуществления студентом индивидуального образовательного маршрута мало связаны со становлением его индивидуальности в диалектическом ключе понимания этого феномена.

Иной взгляд на сущность индивидуального образовательного результата связан с понятием об индивидуальном прогрессе учащегося, под которым понимается 
«позитивное продвижение учащегося в процессе обучения, как положительная динамика предметных, метапредметных и личностных результатов» [3]. Хотя приведенное определение и содержит в себе некую двусмысленность толкования (не вполне понятно, рассматривается ли индивидуальный прогресс непосредственно как индивидуальный образовательный результат, либо речь идет только об индивидуальной динамике общих результатов, единых для всех учащихся), внимания заслуживает сама идея оценки достижений учащихся не по отношению к единому, нормативно заданному эталону, а в сравнении с проявленным ранее уровнем развития самого ученика. И все же исходное противоречие сохраняется и в этом случае: динамика индивидуального продвижения в учебном материале еще не говорит о субъектности ученика в выборе направления и конечных целей этого продвижения. Маршрут остается индивидуальным лишь в части выбора учеником из того, что уже существует в готовом, завершенном виде как подлежащее усвоению содержание образования. Собственно культуротворческая функция образования, с которой связано глубинное понимание индивидуальности и индивидуализации, и в этом случае отсутствует.

Еще один путь к пониманию сущности индивидуального образовательного результата ученика связан с компетентностным подходом, который стал активно применяться в проектировании образовательных систем с внедрением Федеральных государственных образовательных стандартов. Разумеется, было бы неправомочным рассматривать индивидуализацию и компетентностный подход как синонимы, однако тесная взаимосвязь между ними безусловно существует. Так, например, в исследовании творческого коллектива под научным руководством А.А. Попова говорится о том, что с компетеностым подхо- 
дом связаны такие принципы построения образовательного процесса, как «развитие у учеников способностей, позволяющих самостоятельно работать с проблемными ситуациями и решать их; ориентация на практическое освоение тех или иных способностей; построение обучения через адапти-рованный опыт и т.д.» [77, с. 28]. Развивая далее эту мысль, авторы дают следующее определение компетенции: «это рефлексивная возможность человека по саморазмещению (или по капитализации) своего или коллективного накопленного ресурса и потенциала» $[77$, c. 31]. В этой логике индивидуальность и есть результат «капитализации» ресурса, открывающей субъекту новые возможности и горизонты жизнедеятельности. В то же время отождествить индивидуальный образовательный результат с обретенной компетенцией в данном смысле не представляется возможным, поскольку понятия «саморазмещение» и «капитализация» определяют лишь один вектор проявления субъектности: от внешнего опыта - к индивидуальным возможностям его использования субъектом в решении собственных проблем. В то же время изначальное проявление собственной творческой и, что не менее важно, избирательной активности субъекта в определении проблемного поля своего продвижения и полагании его конечного результата и в этом случае остается за рамками рассмотрения.

Таким образом, следует признать, что для определения понятия индивидуального образовательного результата существующие подходы недостаточны. Ни само по себе продвижение ученика в учебном материале с некими «вариациями» и отклонениями от общей нормы, ни «индивидуальный прогресс», ни освоенные компетентности не дают полного представления об ученике как о субъекте культурно-исторического прогресса и его индивидуальности как о процессе и результате творческого преобразо- 
вания окружающей действительности. Можно также утверждать, что для решения этой проблемы недостаточен и понятийный аппарат, обычно применяемый исследователями для описания индивидуальных образовательных траекторий и маршрутов учащихся. Для изменения этой ситуации, на наш взгляд, необходимо дополнить тезаурус исследований понятиями «отношение» и «готовность». Первое из них (отношение) возникает в контексте развития познавательных мотивов и интересов учащихся. Так, в статье Н.А. Савиновой [84] приводятся данные о том, что во многих исследованиях формирование познавательных интересов и, в целом, мотивация учебной деятельности непосредственно связаны с потребностями учащихся в самореализации и со становлением на этой основе их субъектного отношения к образовательному процессу. При этом сам образовательный интерес проявляется как особое избирательное отношение ребенка к окружающему миру, выступая при этом одновременно средством обучения, мотивом и свойством личности. Мы предполагаем, что формирование собственного осмысленного отношения ребенка к объектам и явлениям познаваемой действительности (как было сказано, этот процесс происходит в форме освоения различных социокультурных практик) является не только средством и условием, но и компонентом индивидуального образовательного результата, поскольку становление этого отношения завершает «культуропорождающее», творческое действие, проходящее, как было показано в наших прежних исследованиях, ступени проблематизации, проектирования, действия и рефлексии [32]. В процессе прохождения учащимся индивидуальной образовательной траектории определяемое им отношение к освоенным практикам является связующим звеном между его собственным Я и Культурой, «навигатором», при помощи которого им мо- 
гут избираться стратегические направления дальнейшего продвижения. Как компонент индивидуального образовательного результата построенное отношение выступает основанием, на котором учащийся ищет ответы на смысложизненные вопросы «кто я?» и «зачем я?» в процессе своего личностного самоопределения.

Однако само по себе отношение к осваиваемым содержаниям культуры не исчерпывает собой понятие индивидуального образовательного результата, поскольку это отношение необходимо реализовать в деятельности, носящей творчески-преобразовательный характер. Только в этом случае оно (отношение) может стать подлинным следствием собственной творческой активности субъекта, реализованном во взаимодействии с другими людьми (что, как было сказано, и составляет суть индивидуальности). В свою очередь, для этого субъекту необходимы деятельностные средства, спектр которых выявляется на «разрыве» становящихся потребностей и наличных возможностей их удовлетворения. Таким образом, если само по себе отношение выступает «навигатором» выстраиваемой субъектом индивидуальной образовательной траектории, то освоение новых преобразовательных средств выполняет роль «двигателя», обеспечивающего достижение субъектом поставленных целей. В этой связи возникает необходимость введения в тезаурус нашего исследования понятия готовности, поскольку именно оно позволяет интегрировать в единое целое отношения и преобразовательные средства субъекта. В структуре готовности, которая в прежних исследованиях была определена нами как «системное качество личности, позволяющее ей реализовать в осуществляемой деятельности собственную субъектность и получать личностно значимые результаты» [32, с. 48], отношение представляет собой ее мотивационно-целевой компонент, «отвечающий» за ценностно де- 
терминированный выбор целей преобразовательнотворческой деятельности и, соответственно, определение круга решаемых «задач-на-смысл». Осваиваемые средства этой деятельности представляют собой содержательный компонент готовности решать эти задачи.

Однако этих двух компонентов еще недостаточно для целостной характеристики индивидуального образовательного результата. Необходимо учесть и третий компонент готовности - процессуальный, состоящий в способности субъекта к саморегуляции индивидуальной и групповой деятельности в сотрудничестве с другими людьми. Особенности деятельности субъекта здесь связаны с тем, что одни и те же задачи могут решаться им поразному в соответствии с уровнем собственных социальных притязаний. Такой уровень, определяемый самим субъектом деятельности, также выступает важной характеристикой его индивидуальности, поскольку от него зависит сам смысл, то есть «индивидуальное значение» решаемой задачи. В нашем исследовании мы выделяем три возможных уровня социальных притязаний, характеризующих индивидуальный образовательный результат. Первый - это уровень свободной пробы, на котором учащимся может быть выявлен свой интерес к ее объекту. Интересом, собственно, и ограничивается здесь определяемое субъектом отношение. Совершая пробу, учащийся, в первую очередь, эмоционально оценивает достигнутый результат: интересно, или не интересно; «захватывает», или оставляет равнодушными т.д. На данном уровне освоение новых деятельностных средств, безусловно, необходимо, но не имеет решающего значения: эти средства могут быть достаточно просты. Но эта кажущаяся «простота» для самого ребенка успешно компенсируется включением творческого воображения, в котором совершаемая проба обретает черты достаточно сложного, многоплано- 
вого действия. (О ведущей роли творческого воображения в процессе пробного действия достаточно много сказано в современных психологических исследованиях [55].) Источником становящегося отношения ребенка к объекту своей свободной пробы выступает на данном уровне социальных притязаний отнюдь не социальная значимость достигнутого результата, а «схваченный смысл» (термин В.Т. Кудрявцева) того социального явления или объекта, над которым совершена эта проба. Поэтому данный уровень социальных притязаний не предполагает значительной степени ответственности субъекта, необходимым и достаточным условием совершения успешной пробы здесь является затронутая «точка удивления» ребенка. Все это придает свободной пробе выраженный характер игры, что, в свою очередь, делает ее основным средством достижения индивидуального образовательного результата в младшем возрасте, начиная с дошкольного и заканчивая младшим подростковым. Если этот уровень социальных притязаний и в дальнейшем остается доминирующим при полагании индивидуальных образовательных результатов, это, вероятнее всего, может привести к появлению у ученика интересного для него занятия-хобби, но не более того.

На рубеже младшего и старшего подросткового возраста начинает доминировать новый (второй) уровень социальных притязаний, который мы определяем как социально-адаптивный. Совершаемая учащимся проба становится для него средством опережающей адаптации ко «взрослой» социальной среде. Подростку необходимо убедиться в собственном соответствии ожиданиям со стороны общества и своей готовности вступать с ним (обществом) в новые для себя отношения, отмеченные более высоким уровнем самостоятельности и социальной ответственности. Индивидуальные образовательные результа- 
ты на данном уровне базируются на социальных мотивах самоутверждения и принятия себя другими людьми. Ведущая роль этих мотивов была убедительно доказана в исследованиях Д.И. Фельдштейна [94]. Для их реализации учащимся необходимы более сложные (даже «авангардные») деятельностные средства, которые обеспечивают реальную социальную значимость достигаемых результатов. Однако вопрос о преобразовательно-творческом характере этих средств может стать проблематичным для учащегося, поскольку здесь начинает обозначать себя противоречие между профессиональным и личностным самоопределением, на которое указывает Н.С. Пряжников [81]. Если личностное самоопределение свободно по своей сути и носит сугубо творческий, неадаптивный характер, то профессио-нальное самоопределение достаточно жестко детерминировано внешнезаданными социальными нормами. В этой связи у учащегося как субъекта проектирования индивидуальных образовательных результатов возникает дилемма выбора дальнейшей стратегии продвижения по индивидуальной образовательной траектории. Адаптивная стратегия (в реальной ситуации профессионального самоопределения она может трансформироваться в «тыловую» стратегию, основанную, как отмечает Н.С. Пряжников, на подготовку надежных «тылов» на случай неудачи по основному варианту) приводит, в конечном счете к «ремесленничеству», неадаптивная стратегия - к подлинному мастерству и творчеству. Поэтому адаптивный уровень социальных притязаний представляет собой своего рода «развилку», где субъекту необходимо самоопределиться в своем смысловом отношении к будущей деятельности и социальной карьере.

И, наконец, третий уровень социальных притязаний, который мы определяем как ценностно-смысловой, либо как уровень личностного самоопределения, по своей сути 
связан с мотивами творческой самореализации и самоактуализации. На этом уровне индивидуальные образовательные результаты полагаются субъектом в контексте его представлений о призвании и максимуме творческих достижений. Отношения субъекта к окружающей действительности формируются здесь на основе его смыслопоисковой, неадаптивной активности и базируются на принятии определенного круга культурных ценностей. Высокий уровень не только социальной, но и личной ответственности определяет необходимость освоения особых деятельностных средств, обеспечивающих субъекту свободу в принятии креативных решений и выстраивании коммуникаций с другими людьми в нестандартных ситуациях совместного решения творческих задач.

Таким образом, наше исследование позволяет утверждать, что индивидуальные образовательные результаты, проектируемые самим субъектом освоения индивидуальной образовательной траектории, не сводятся ни к избираемым «фрагментам» учебного материала, ни к формальному приращению социального опыта конкретного индивида, ни к обретенным компетентностям в поле социально заданного круга компетенций. Ни в одном из этих вариантов данное понятие не характеризует учащегося как субъекта культурно-исторического процесса. В этой связи может быть предложено следующее рабочее определение данного понятия: индивидуальный образовательный результат - совершенный субъектом шаг продвижения по индивидуальной образовательной траектории, в ходе которого им осваивается и реализуется новое средство для решения определенного круга творческих задач, определяемого на основе его индивидуального отношения к объектам и явлениям окружающего мира и в соответствии с уровнем собственных социальных притязаний. 
1.3. Возрастные характеристики индивидуальных образовательных результатов учащихся

Рассматриваемая проблема имеет еще один крайне важный аспект, связанный с учетом возрастных особенностей учащихся. В «обычных» образовательных системах, в которых образовательные результаты представляют собой достигнутые уровни усвоения единых образовательных программ, этот учет сводится к корректировке объема и сложности подлежащей усвоению учебной информации учащимися разного возраста. Характерно в этом смысле, что даже требования к образовательным результатам учащихся на разных ступенях общего образования, определяемые действующими Федеральными государственными образовательными стандартами общего образования, не дают достаточно полного и четкого представления о том, в чем именно должны состоять качественные различия между образовательными достижениями учащихся начальной, основной и средней общеобразовательной школы. Однако при переходе в логику проектирования систем индивидуализированного образования, основанную на первичности ребенка как субъекта построения индивидуальной образовательной траектории, суть «учета индивидуальных особенностей» существенно изменяется. Связано это с тем, что в каждом проживаемом возрасте ребенок не только использует специфические средства, при помощи которых он познает и преобразует окружающую действительность, но и занимает по отношению к ней специфическую внутреннюю позицию. Так, в исследованиях Д.И. Фельдштейна отмечено закономерное чередование внутренних позиций ребенка «Я и общество» и «Я в обществе», доминирующих на разных возрастных этапах его развития [94]. Поэтому достигаемые им обра- 
зовательные результаты только тогда действительно становятся индивидуальными, когда проявляется их соответствие этим позициям и средствам.

Данный параграф посвящен описанию онтогенеза индивидуальных образовательных результатов учащихся разного возраста - от дошкольного до старшего школьного. Цель проведенного исследования состояла в выявлении специфических особенностей индивидуальных образовательных результатов учащихся дошкольного, младшего школьного, подросткового и раннего юношеского возраста.

Для достижения поставленной цели мы использовали метод моделирования ситуаций освоения учащимися разного возраста проблематизированных социокультурных практик, входе которого, как было показано в наших предшествующих исследованиях, ими решаются разнообразные творческие задачи в условиях событийной общности с другими людьми [32]. Как было сказано, главным методологическим основанием для нас выступал принцип первичности субъекта освоения внешней среды как носителя творческой активности (Дж. Гиббсон, Г.П. Щедровицкий, В.Т. Кудрявцев, В.А. Петровский и др.). В качестве ведущих теоретических оснований мы использовали теории ведущей деятельности развития (А.Н. Леонтьев) и продуктивного пробного действия (Б.Д. Эльконин), в рамках которых совершение деятельностных проб выступает механизмом творческого освоения детьми разного возраста проблематизированных содержаний культуры.

В предыдущем параграфе мы обосновали индивидуальный образовательный результат как совершенный субъектом шаг своего продвижения по индивидуальной образовательной траектории, открывающий ему новые 
возможности самостоятельного решения определенного круга творческих задач. Эти возможности соотносятся самим субъектом с уровнем собственных социальных притязаний, что позволяет выявить и оценить их индивидуальное значение для этого субъекта. Развивая эти представления, отметим, что исходным проявлением творческой активности субъекта в этой системе взглядов и представлений выступает продуцирование им своего собственного «запроса к Культуре», в основе которого лежит социокультурная проблематика проживаемого возрастного периода. Эта идея, в частности, была заложена в основу проекта Всероссийской системы оценки качества образования, разработанная в русле системно-деятельностного подхода, но, к сожалению, не получившая в полной мере своего практического воплощения. В частности, авторы этого проекта отмечают следующее: «Первый и основной результат любого образовательного действа состоит не в том, что он (ребенок - В.И.) делает, а в том, с чем он обращается к взрослому (учителю). То есть первое, что в результате правильной образовательной программы... будет выстроено и через всю жизнь человеком пронесено - это формирование и наличие у него образовательного запроca. Образовательный запрос - в том хитрость его как результата, что он инициируется, что он происходит как свой запрос от ребенка» [101, с. 38]. Идея такого «запроса» восходит к культурно-исторической концепции Л.С. Выготского и, по сути, является ключом к пониманию творческой природы самого процесса психического развития ребенка. В рамках этих представлений индивидуальный образовательный результат ученика может интерпретироваться исключительно как найденный им «ответ» на его же собственный «запрос к культуре». Обратное также верно: если образовательные результаты ученика не свя- 
заны с его собственным «запросом», они по определению не могут рассматриваться как индивидуальные. Иначе утрачивается сам смысл индивидуальности как процесса и результата самосотворения человека в активнодеятельном общении с другими людьми [95].

В этой связи могут быть выделены три вида индивидуальных образовательных результатов, отвечающих общей логике самостоятельного освоения учащимся проблематизированных социокультурных практик на разных возрастных этапах развития.

В первую очередь, это образовательные результаты как обретенные субъектом смыслы осваиваемых им содержаний Культуры. С точки зрения психологической теории смысла, этот результат состоит в определении субъектом индивидуального значения («значения-длясебя») того знания (более широко - опыта), которое обретено им в процессе творческого освоения различных социокультурных практик. Эти смыслы образуют содержательное ядро формирующегося «ответа» самого субъекта на его «запрос». Здесь следует учитывать, что не каждая попытка учащегося освоить ту или иную социокультурную практику может иметь следствием определение им своего смыслового отношения к ней. С этим связано крайне важное отличие индивидуальных и «обычных» образовательных результатов. «Обычные» результаты должны достигаться всеми учениками, совершающими запрограммированные учебные действия. В случае же индивидуальных результатов-смыслов такое требование уступает место противоположному взгляду: «непорождение» субъектом смысла также может рассматриваться как результат - понимание того, что данная конкретная социокультурная практика в настоящее время не может стать 
единицей его индивидуальной образовательной траектории. Так, например, осваивая такую социокультурную практику, как эмоционально-включенное чтение художественного текста, ученик может не открыть до поры до времени своего собственного смысла в том или ином литературном произведении (хотя имеет шанс сделать это впоследствии). Но ведь именно способность смысловой сферы человека строить избирательные отношения с окружающим миром лежит в основе развития его индивидуальности. В отличие от всеобщих значений, смыслы не могут быть обретены человеком «по указке» извне, их избирательность, как отмечает, в частности, Д. А. Леонтьев, выступает механизмом ориентирования человека в мире [59]. Но при этом закономерно возникает вопрос о совместно-разделенной ответственности взрослого и ребенка, который может быть сформулирован следующим образом: были ли в полной мере реализованы ресурсы их педагогического взаимодействия, необходимые для открытия учеником собственного смысла в предъявленном ему содержании Культуры? Заметим, что в таком виде вопрос практически не возникает при ориентации педагога на усвоение учеником лишь общепринятых значений тех или иных явлений окружающего мира, то есть вне контекста индивидуализации образования.

Второй вид индивидуальных образовательных результатов мы определяем, как результаты - способы продуктивных действий. Разумеется, необходимость освоения учащимися способов действий (в первую очередь учебных) не отрицается и в неиндивидуализированных образовательных системах. В рамках так называемой «знаниевой парадигмы» для этого используются понятия «умения» и «навыки». Принципиальное отличие состоит в том, что вне контекста индивидуализации осваиваемые 
учеником способы действий носят самодостаточный характер и внедряются в его сознание посредством демонстрации образцов и их воспроизведение учениками в заранее подготовленных учебных ситуациях. В рамках компетентностного подхода формируемые таким путем способы действий иногда именуются «репродуктивными компетенциями». В качестве же альтернативы используется понятие «продуктивные компетенции», основанные на «самости, экзистенциальной основе любой субъектности, отличительной особенностью которых выступает «более рефлексивный антропологический и культурный характер» [77, с. 53]. В контексте же индивидуализации смысловой акцент понятия «способы продуктивных действий» приходится на расширение возможностей субъекта самостоятельного решения им определенного круга творческих задач.

В этой связи достижение учащимся индивидуального образовательного результата - способа продуктивного действия характеризуется двумя взаимодополняемыми сторонами. С одной стороны, открывая для себя новые «поля Культуры», учащийся сталкивается с необходимостью освоения новых способов действий, которых до сих пор не было в его арсенале. Их освоение становится для него личностно значимой задачей, если эти содержания соотносятся в сознании с тем самым исходным «запросом к Культуре», который лежит в основе его смыслообразующих мотивов. С другой стороны, опыт применения уже освоенных способов продуктивных действий может стать основанием для расширения круга решаемых с их использованием проблемных задач. Другими словами, перенос имеющегося опыта в новые сферы его применения становится механизмом расширения творческих возможностей субъекта. И в том, и в другом случае достижение индиви- 
дуального образовательного результата -способа продуктивного действия - сопровождается личностной рефлексией состоявшегося шага продвижения субъекта по индивидуальной образовательной траектории.

Нетрудно заметить, что представления об образовательных результатах как обретенных смыслах и освоенных способах действий опираются на учение Д.Б. Эльконина о единстве смысловой и операциональной сторон продуктивной деятельности субъекта [107]. В свою очередь концепция продуктивного действия Б.Д. Эльконина выводит нас на понимание третьего вида индивидуальных образовательных результатов - освоенных учащимся способов социального утверждения совершаемых им действий и поступков. Как отмечает автор, «...продуцирование предполагает социальную пробу образования и удержания того социума..., в котором действие будет практически экранировано в виде ожиданий, оценки, санкций сообщества людей, которые будут смотреть на действующего, а не сквозь него... [104]. Вопрос состоит в том, выступает ли это «социальное утверждение» задачей для самого субъекта деятельности? Отвечая на него положительно, отметим, что именно данный вид индивидуальных образовательных результатов лежит в основе способности человека создавать новые социальные институты, становясь, таким образом, субъектом инновационных процессов в обществе.

Далее в логике проводимого исследования нам было необходимо охарактеризовать специфику выделенных видов индивидуальных образовательных результатов учащихся на различных этапах их возрастного развития. Результаты этой работы представлены в таблице 1. 
Таблица 1.1. Общие характеристики индивидуальных образовательных результатов учащихся на разных этапах онтогенеза

\begin{tabular}{|c|c|c|c|}
\hline $\begin{array}{l}\text { Возраст и } \\
\text { «запрос к } \\
\text { Культуре» }\end{array}$ & $\begin{array}{c}\text { ИОР - } \\
\text { смыслы }\end{array}$ & ИОР - СПД & ИОР - ССУ \\
\hline $\begin{array}{l}\text { Дошкольный: } \\
\text { «видеть все», } \\
\text { «творить все» } \\
\text { и «быть всем» }\end{array}$ & $\begin{array}{l}\text { Универсаль- } \\
\text { ные смыслы } \\
\text { отношений } \\
\text { между людь- } \\
\text { ми в условиях } \\
\text { разнообразия } \\
\text { окружающей } \\
\text { действитель- } \\
\text { нос-ти } \\
\end{array}$ & $\begin{array}{l}\text { Игровое моде- } \\
\text { лирование явле- } \\
\text { ний окружающе- } \\
\text { го мира, свобод- } \\
\text { ное эксперимен- } \\
\text { тирование с ни- } \\
\text { ми средствами } \\
\text { творческого во- } \\
\text { ображения }\end{array}$ & $\begin{array}{l}\text { Внутрен- } \\
\text { няя адреса- } \\
\text { ция совер- } \\
\text { шаемых } \\
\text { игровых } \\
\text { действий } \\
\text { Другому } \\
\text { (взросло- } \\
\text { му) } \\
\end{array}$ \\
\hline $\begin{array}{l}\text { Младший } \\
\text { школьный: } \\
\text { овладение } \\
\text { «взрослыми» } \\
\text { средствами } \\
\text { познания ми- } \\
\text { ра }\end{array}$ & \begin{tabular}{ll}
\multicolumn{3}{l}{ Осмысление } \\
мира & как \\
«приглаше- \\
ния» к & по- \\
знанию & че- \\
рез творче- & тво \\
ство &
\end{tabular} & $\begin{array}{l}\text { Отделение зна- } \\
\text { ния от незнания; } \\
\text { построение, реа- } \\
\text { лизация и про- } \\
\text { верка схемы вы- } \\
\text { полнения зада- } \\
\text { ния; обращение к } \\
\text { внешним ресур- } \\
\text { сам для решения } \\
\text { поставленной } \\
\text { задачи }\end{array}$ & $\begin{array}{l}\text { Адресация } \\
\text { значимому } \\
\text { Другому } \\
\text { «правиль- } \\
\text { ного» ре- } \\
\text { шения по- } \\
\text { ставленной } \\
\text { задачи }\end{array}$ \\
\hline $\begin{array}{l}\text { Подростко- } \\
\text { вый: вопрос о } \\
\text { «главном ин- } \\
\text { тересе», соб- } \\
\text { ственной } \\
\text { идентично- } \\
\text { сти и группо- } \\
\text { вой принад- } \\
\text { лежности }\end{array}$ & $\begin{array}{l}\text { Определение } \\
\text { субъектив- } \\
\text { ного (пози- } \\
\text { тивное - } \\
\text { негативное) } \\
\text { смыслового } \\
\text { отношения } \\
\text { к различным } \\
\text { видам соци- } \\
\text { ально ори- }\end{array}$ & $\begin{array}{l}\text { Tворческое пре- } \\
\text { образование } \\
\text { проблемных си- } \\
\text { туаций и позна- } \\
\text { ваемых объек- } \\
\text { тов окружающе- } \\
\text { го мира; взаимо- } \\
\text { действие и со- } \\
\text { трудничество с } \\
\text { партнерами по по }\end{array}$ & $\begin{array}{l}\text { Презента- } \\
\text { ция себя и } \\
\text { результа- } \\
\text { тов своей } \\
\text { деятельно- } \\
\text { сти сов- } \\
\text { местно с } \\
\text { другими ее } \\
\text { субъектами } \\
\text { в социаль- }\end{array}$ \\
\hline
\end{tabular}




\begin{tabular}{|c|c|c|c|}
\hline & $\begin{array}{l}\text { ентирован- } \\
\text { ной дея- } \\
\text { тельности; } \\
\text { осмысление } \\
\text { себя как } \\
\text { субъекта } \\
\text { выбора }\end{array}$ & $\begin{array}{l}\text { совместной дея- } \\
\text { тельности; ре- } \\
\text { флексия и само- } \\
\text { оценка резуль- } \\
\text { татов осуществ- } \\
\text { ляемой творче- } \\
\text { ской деятельно- } \\
\text { сти }\end{array}$ & $\begin{array}{l}\text { но одобря- } \\
\text { емых } \\
\text { мах }\end{array}$ \\
\hline $\begin{array}{l}\text { Ранняя } \\
\text { юность: во- } \\
\text { прос о ресур- } \\
\text { сах дальней- } \\
\text { шей социали- } \\
\text { зации, лич- } \\
\text { ностного и } \\
\text { профессио- } \\
\text { нального са- } \\
\text { моопределе- } \\
\text { ния }\end{array}$ & $\begin{array}{l}\text { Осмысление } \\
\text { себя как } \\
\text { субъекта } \\
\text { жизни; } \\
\text { осмысление } \\
\text { образования } \\
\text { как ресурса } \\
\text { построения } \\
\text { социальной } \\
\text { и професси- } \\
\text { ональной } \\
\text { карьеры }\end{array}$ & $\begin{array}{l}\text { Выстраивание } \\
\text { индивидуальной } \\
\text { образователь- } \\
\text { ной траектории } \\
\text { на последующих } \\
\text { ступенях непре- } \\
\text { рывного образо- } \\
\text { вания (образо- } \\
\text { вательная само- } \\
\text { стоятельность); } \\
\text { реализация ав- } \\
\text { торского проек- } \\
\text { та; деловое со- } \\
\text { трудничество с } \\
\text { другими людьми }\end{array}$ & $\begin{array}{l}\text { Общест- } \\
\text { венная за- } \\
\text { щита инди- } \\
\text { видуально- } \\
\text { го проекта; } \\
\text { презента- } \\
\text { ция себя и } \\
\text { результатов } \\
\text { своей дея- } \\
\text { тельности } \\
\text { различным } \\
\text { аудиториям }\end{array}$ \\
\hline
\end{tabular}

Примечание: ИОР - индивидуальные образовательные результаты; СПД - способы продуктивных действий; ССУ - способы социального утверждения.

Источник: составлено соавторами монографии.

Source: compiled by the co-authors of the monograph.

«Запрос к Культуре», исходящий от дошкольника, психолог В.Т. Кудрявцев определяет как «видеть все», «творить все» и «быть всем» [55]. Такой запрос полностью отвечает особенностям психики ребенка в этом возрасте: полная открытость всему многообразию проблемных содержаний окружающей действительности, примат смыс- 
ловой стороны осуществляемой деятельности над операциональной, насыщенность и надситуативность и т.д. В этом возрасте ребенок стремится максимально насытить свою эмоциональную сферу переживаниями, источниками которых становятся затронутые «точки удивления». Главным и по сути единственным средством для решения этой задачи выступает его творческое воображение. Именно этим объясняются особенности охарактеризованных индивидуальных образовательных результатов. Пропуская через свое сознание каждое явление окружающего мира и прорабатывая его силой воображения, в первую очередь, средствами игровой деятельности, ребенок способен отразить его как целостность, осмыслить его в главном, не обращая покуда своего внимания на технические детали и подробности. По утверждению В. Т. Кудрявцева, именно «схватывание» универсальных смыслов становится для ребенка главным результатом соприкосновения с проблемными содержаниями Культуры. В качестве примера такого «схватывания» В. Т. Кудрявцев описывает поведение малыша, «оседлавшего» палочку и таким путем «превратившего» ее в лошадку. «Схватывание» смысла интерпретируется как «освобождение» этого действия от всего избыточного, в результате чего в самом ребенке «освобождается» наездник, которым он становится в игре. Тем самым ребенок освобождает «другого человека, который уже где-то притаился в нем, но не было волшебного жезла (палочки), чтобы вызволить... Этот «другой», как джинн, однажды выпущенный из сосуда, превращается в спутника на всю жизнь» [55].Смысл, извлеченный ребенком из игровой ситуации, становится для него, по сути, опытом «быть другим» и ощущать, каково этому «другому». Из этих универсальных смыслов ребенок-дошкольник складывает свою субъективную картину 
мира, «приглашающую» к его творческому освоению и свободному экспериментированию.

Соответственно, основным способом продуктивного действия, который осваивает ребенок именно как свой собственный, индивидуальный образовательный результат, становится для него моделирование затронувших его воображение явлений окружающего мира в форме сюжетно-ролевой (либо режиссерской) игры. В ходе такой игры творческое воображение становится для ребенка средством, при помощи которого он может свободно экспериментировать с заинтересовавшими его содержаниями Культуры, что и приводит к порождению его смысловой картины мира.

Как способ продуктивного действия игровое моделирование обладает для ребенка-дошкольника важнейшим свойством, на которое указывает Б.Д. Эльконин: порожденное в проблемной ситуации средство решения творческой задачи (способ продуктивного действия) становится для субъекта инструментом, при помощи которого он может совершать последующие пробы, выходя при этом за пределы уже существующего опыта [106]. (В скобках отметим, что игровая ситуация как раз содержит в себе проблемную задачу, для решения которой необходимо преобразовать эту ситуацию средствами творческого воображения.) Именно в этом состоит механизм развития игры как ведущей деятельности развития дошкольника.

Вопрос о третьем виде индивидуальных образовательных результатов в дошкольном возрасте - освоенных способов социального утверждения совершаемых действий - может быть рассмотрен с двух разных позиций. Так, в общем ключе обсуждения социализирующих эффектов детской игры уместно обратиться к идее «детского общества», обоснованной Г.П. Щедровицким. Рассматривая игру как модель отношений субъектов «взрослого» 
общества, он отмечал, что «сами общественные и нравственные нормы могут задаваться детям в качестве особых содержаний усвоения тоже только в ситуациях, возникающих по поводу игры, именно в конфликтных ситуациях, ибо только здесь они могут быть использованы в качестве средств разрешения конфликта и только здесь ребенок может увидеть и понять их роль в качестве таких средств» [102]. Бесспорно, что способность ребенка достигать определенные договоренности с партнерами по игровой деятельности лежит в основе его будущей готовности к порождению новых социальных институтов, что выступает важнейшим аспектом социализации. Однако едва ли можно утверждать, что эти договоренности направлены на социальное утверждение самой игры, поскольку реальный социум персонифицируется в сознании ребенка образом взрослого, который может и вовсе не принимать участия в отношениях «по поводу игры». Поэтому подход к пониманию этого вида индивидуальных образовательных результатов детей-дошкольников следует искать в новых способах взаимоотношения ребенка со взрослыми. При этом «натуральное» участие взрослого в детской игре, хотя и может выступать источником ее развития, не имеет отношения к ее социальному утверждению. Ключом к ответу на данный вопрос может служить следующий пример (из лекций В. Т. Кудрявцева). Ребенок дошкольного возраста строил башню из кубиков в присутствии взрослых людей, пришедших в гости. Попытки взрослых поучаствовать в строительстве башни были им отклонены, однако, когда гости из гостиной перешли на кухню, он молча собрал свои кубики и проследовал за ними, где начал «строительство» заново. Объясняя этот феномен, В.Т. Кудрявцев отмечает, что истинной причиной, побудившей ребенка совершить такой поступок, выступает то, что свое «игрушечное» строительство он внутренне 
адресовал именно тем взрослым людям, которые при этом присутствовали. Таким путем он оценивал самого себя через Другого человека, то есть взрослого. Можно сказать, что именно на полюсе взрослого Другого в данный момент был локализован «полюс социального значения» осуществляемой ребенком деятельности. Таким образом, адресуя свою игру взрослому, ребенок стремился к ее социальному утверждению, превращая в своем воображении «игру понарошку» во вполне серьезную, социально одобряемую деятельность. Сказанное позволяет нам заключить, что внутренняя адресация творческой деятельности ребенка взрослому человеку в дошкольном возрасте становится для него освоенным способом социального утверждения этой деятельности, то есть важным индивидуальным образовательным результатом.

Переходя к описанию индивидуальных образовательных результатов учащихся младшего школьного возраста, отметим, что, как и дошкольник, младший школьник еще не в состоянии самостоятельно сформулировать (вербализовать) свой запрос. По утверждению авторов уже упомянутой Школьной системы оценки результатов и качества общего образования, «у него (младшего школьника - В.И.) есть отдельные просьбы, отдельные требования и т.д. Что есть его образовательные задания? Первое, с чего он начинает, это задания правильного выполнения чего-либо в соответствие с некой схемой. А когда он заканчивает, то это задание удержания схемы выполнений, то есть построения схемы и проверка ее выполнения» $[101$, с. 39.]. Сказанное в полной мере характеризует учебную деятельность младшего школьника, единицей которой, согласно теории В. В. Давыдова, Д. Б. Эльконина выступает решение учебной задачи. Однако есть основания полагать, что учебная деятельность, являясь ведущей деятельностью развития младшего школьника, все же не 
замыкает на себя его индивидуальный «запрос к Культуре». Этот запрос формируется в более широком контексте творчества и подчиняется особенностям социальной ситуации развития ребенка в этом возрасте. Одной из главных особенностей выступает то, что помимо творческого воображения ребенок открывает для себя и осваивает иные, настоящие, «взрослые» средства познания и отражения окружающего мира. Благодаря этим средствам ребенок может открыть для себя «внутреннее устройство» окружающих его вещей и явлений. Совершаемые им пробы могут относиться к разным сферам творческой деятельности, например, в сфере изобразительного искусства. Так, в процессе рисования пейзажа ребенок может открыть закон перспективы, и это станет для него существенным шагом продвижения по индивидуальной образовательной траектории. Важно, что это и другие открытия становятся результатом именно пробных продуктивных действий. Как пишет по этому поводу Б.Д. Эльконин, «...живописец, накладывающий цветовое пятно на холст, делает это размерно, осторожно, как бы следуя всем "правилам" пробно-поискового действия. Но эта «проба» здесь же, а не после построения "полной ориентировочной основы", претворяется в результат - цветовое пятно, которое, в свою очередь, станет или не станет элементом целого в зависимости от "попадания" в форму композиции....» [106]. Именно таким путем способен совершать свои открытия младший школьник, и именно они становятся для него источником новых смыслов. В целом, окружающая действительность осмысляется ребенком младшего школьного возраста как поле деятельности, приглашающее к его творческому освоению при помощи субъективно новых «взрослых» творческих средств. Искомые смыслы для младшего школьника «спрятаны» внутри познаваемых объектов и явлений и могут быть извлечены оттуда 
исключительно с помощью особых, «правильных» действий. Именно этим можно объяснить готовность младшего школьника занять внутреннюю позицию «я в обществе» (по Д.И. Фельдштейну), или, в более широком смысле, «я в реальном мире». Реальный мир открывается для младшего школьника как источник новых смыслов, становясь при этом альтернативой ранее обжитому миру воображаемому.

Именно эти, ранее скрытые, но извлеченные при помощи «правильных» действий смыслы как секреты внутреннего устройства мира, становятся для ребенка младшего школьного возраста его индивидуальными образовательными результатами. На их основе выстраивается новая картина мира, «приглашающего» человека к его познанию творческими средствами. В свою очередь, сами «правильные» действия, выстраиваемые на основе логических схем, продвигающих учащегося от незнания - к знанию, становятся его индивидуальными образовательными результатами - обретенными способами продуктивных действий. Каждый из таких результатов становится для ребенка его собственным открытием, с которым связаны новые возможности творческого познания и отражения окружающего мира. Однако освоение «правильного» способа выполнения продуктивного действия ценно не само по себе, а исключительно потому, что оно приводит ученика к решению творческой задачи. Именно обретенная возможность решения творческой задачи делает освоенный способ продуктивного действия индивидуальным образовательным результатом младшего школьника.

Что же касается осваиваемых в этом возрасте способов социального утверждения собственных продуктивных действий, то, как и в дошкольном детстве, они связаны, в первую очередь, с особыми коммуникациями со взрослыми людьми. Оценка взрослого так же, как и раньше, опо- 
средует самооценку самого учащегося. Однако в младшем школьном возрасте изменяется внутренняя позиция ребенка (субъекта), благодаря чему он начинает осознанно оценивать себя (и свою деятельность) именно глазами взрослого человека, ориентируясь при этом на «правильность» выполняемых действий. Таким образом, способом социального утверждения действий ученика выступает не сама по себе оценка, выносимая взрослым, а самооценка учащегося, которую он осуществляет глазами взрослого человека, ориентируясь при этом на соответствие осуществленного действия «правильной» схеме, приводящей к решению творческой задачи. Участие взрослого в процедурах оценивания является необходимым (но не достаточным) условием социального утверждения. Возможность ребенка оценить себя глазами взрослого предполагает использование особого способа субъект-субъектных взаимодействий между ними, при котором ребенок овладевает средствами самооценки достигаемых результатов. Главным барьером на пути достижения таких индивидуальных образовательных результатов младшего школьника часто становится неготовность взрослых (в первую очередь, учителей и родителей) выстраивать процедуру оценивания именно как субъект-субъектное взаимодействие с ребенком. Следствием такой неготовности, как правило, становится низкий уровень к контрольнооценочной самостоятельности учащегося.

При переходе в подростковый возраст деятельность учащихся, лежащая в основе достижения ими индивидуальных образовательных результатов, существенно изменятся. Как отмечают, в частности, Б.Д. Эльконин и А.Б. Воронцов, подростку, в отличие от младшего школьника, необходимо преобразовать ситуацию, для того чтобы выявить скрытый в ней смысл. Для этого им осваиваются и используются особые «управляющие модели» [101]. Свя- 
зано это с тем, что мир открывается подростку не в статике, а в динамике. Открываемые смыслы связаны, в первую очередь, с возможностями преобразования и «достраивания» того, что вызывает его интерес. Учитывая, что подросток (по Д. И. Фельдштейну) вновь занимает внутреннюю позицию «Я и общество», можно заключить, что его индивидуальная образовательная траектория, проходящая через различные социальные пробы, приводит его к личностному самоопределению как к ответу на три взаимосвязанных вопроса: в чем мой главный интерес? Кто я как уникальная личность? Кто я среди других людей?

Социальная проба подростка отличается тем, что, совершая ее, он решает особую, проектную задачу-на-смысл, который обнаруживается субъектом при преобразовании проблемной ситуации. Извлекаемый смысл непосредственно связан с «разностью потенциалов» между тем, что было, и тем, что стало, которая, по утверждению И.А. Колесниковой, составляет важнейшую характеристику проектной деятельности [46]. Для самого подростка этот смысл возникает как открытие, касающееся не только преобразованного объекта, в котором обнаружились новые, ранее неизвестные свойства и значения, но, в первую очередь, самого субъекта: «для меня это важно!». Именно эти открытия становятся для подростка его индивидуальными образовательными результатами - смыслами. Выделение, выбор в окружающем мире того, что «важнодля-меня» для подростка становится главным механизмом формирования смысловой картины этого мира, а также осознанием себя как субъекта этого выбора.

Особым значением для проектной деятельности подростка как источника новых смыслов обладает ее совместный характер. Взаимодействуя друг с другом и со взрослыми людьми в процессе решения проектных задач, учащиеся подросткового возраста «обмениваются» по- 
рождаемыми смыслами. Результатом этого обмена становится для подростка ответ на его вопрос о собственной групповой принадлежности. Обретенный смысл «важнодля-меня» таким путем трансформируется в общий смысл «важно-для-нас», становясь при этом средством самоидентификации подростка в обществе.

Другая группа индивидуальных образовательных результатов учащихся-подростков (способы продуктивных действий) также соответствует сущности проектной деятельности, а именно, ее творческо-преобразовательному характеру. Такими результатами становятся те способы действий, при помощи которых проблемная ситуация может быть преобразована в соответствии с представлениями субъекта о «желаемом будущем». По сути, они призваны стать для подростка инструментами управления моделируемыми им процессами. Вспомним, что для дошкольника таким универсальным «инструментом» является его творческое воображение. В подростковом возрасте спектр этих инструментов должен стать значительно шире и обеспечивать сочетание, как воображаемых, так и реальных преобразовательных действий. Кроме того, набор освоенных подростков способов преобразовательных действий должен в полной мере соответствовать общей логике совместного решения проектной задачи. В этой связи можно выделить три подгруппы индивидуальных образовательных результатов подростков - способов продуктивных действий. Первую из них составляют индивидуальные действия, направленные на анализ и преобразование проблемной ситуации: понимание и «удержание» решаемой проектной задачи; концептуализация проектного замысла; продуцирование идей; поиск и обработка информации; обращение к необходимым теоретическим знаниям; использование моделей, схем и инструментов; воплощение найденного решения в продукте; 
рефлексия произошедших изменений. Вторую подгруппу образуют способы и средства продуктивных коммуникаций с партнерами по совместной деятельности: принятие персональной и разделенной ответственности; передача и прием сообщений без искажения их смысла; планирование и саморегуляция совместных действий; предотвращение и регулирование конфликтных ситуаций. И третью подгруппу составляют способы действий, лежащих в основе сотрудничества и психологической поддержки: проявление солидарности и доброжелательности; регулирование эмоционального напряжения; проявление уважительного отношения к иным точкам зрения; оказание поддержки в трудных ситуациях. Как и в предыдущих случаях, индивидуальность этих образовательных результатов обеспечивается их встроенностью в контекст решаемой проблемной задачи на «разрыве» имеющегося и необходимого нового опыта.

Способы социального утверждения продуктивных действий подростков (третий вид индивидуальных образовательных результатов) основаны на внутренней адресации осуществляемой деятельности не только взрослым, наделенным «полномочиями» Значимого Другого, но и более широкому кругу представителей внешней социальной среды, например, зрителям на спектакле в театральном кружке, концерте, спортивных соревнованиях и т.д. При этом у подростка возникает необходимость и (как индивидуальный образовательный результат) возможность влиять на внешнюю аудиторию, завоевывать ее внимание и симпатию, а также оценивать, в какой степени состоялось это социальное утверждение. Таким путем подросток отражает в своем сознании самого себя как субъекта социальных отношений. Однако более высоким потенциалом социального утверждения обладают способы взаимодействия с представителями внешней социаль- 
ной среды в специально организуемых форматах общественно-профессиональной экспертизы результатов проектной деятельности. Именно в этом состоит главное назначение всевозможных конкурсов детских проектов. Однако для того, чтобы эти конкурсы действительно стали форматом социального утверждения деятельности подростков, необходимы два условия. Первое - это готовность взрослых участников подобных мероприятий к осуществлению специфических функций экспертов и оппонентов, обеспечивающих их подлинно со-бытийный характер. Презентация и защита подросткового проекта (с учетом возрастных особенностей учащихся) должна представлять собой не «натуральную» встречу автора и эксперта, а, скорее, игровое моделирование такой встречи, в ходе которого эксперт обладает возможностью подчеркнуть реальную социальную значимость образовательных достижений подростка. Следует отметить, что низведение процедур экспертизы и оппонирования до обычной «школьной» оценки или нормоконтроля по стандартным требованиям практически полностью лишают эти процедуры функции социального утверждения действий учащихся. Второе же условие непосредственно выступает индивидуальным образовательным результатом учащегося и состоит в его готовности вести конструктивный диалог с экспертами и оппонирующей аудиторией, доказывая и отстаивая социальное значение осуществленного проекта.

И, наконец, индивидуальные образовательные результаты, присущие юношескому возрасту, формируются в ситуации профессионально-личностного самоопределения. Эта ситуация, отвечающая реалиям современной действительности, характеризуется высокой степенью социокультурной неопределенности, что практически делает неэффективными любые попытки воспроизведения ранее 
известных способов построения профессиональной и социальной карьеры. В этой ситуации наиболее эффективным становится самоопределение, осуществляемое как авторский проект самого ученика, направленный на достижение ценностно детерминированных жизненных целей. Важнейшим условием их достижения становится образовательная самостоятельность учащегося, понимаемая как его готовность к построению индивидуальной образовательной траектории на последующих (послешкольных) этапах непрерывного образования [34]. Ситуацию ранней юности характеризует и возрастание значимости операциональной стороны деятельности учащихся, для полноценного осуществления которой субъекту необходимы разнообразные внешние и внутренние (личностные) ресурсы. Именно этим определяется индивидуальный запрос к Культуре как вопрос о ресурсах дальнейшей социализации, личностного и профессионального самоопределения.

Таким образом, индивидуальные образовательные результаты - смыслы, обретаемые учащимися в ранней юности, связаны, с одной стороны, с осмыслением ценности образования как «двигателя», обеспечивающего продвижение субъекта по индивидуальной образовательной траектории, с другой стороны, с осмыслением самого себя как субъекта выбора и проектирования этой траектории. Источником таких смыслов выступает проектная деятельность, реализуемая учащимися на качественно новом уровне их образовательной ответственности. Этот уровень характеризуется тем, что индивидуальный проект учащегося перестает быть только атрибутом его учебной деятельности и «вписывается» в реальные социальные связи и отношения, вызывая требуемые изменения в окружающей социальной среде. 
Соответственно индивидуальные образовательные результаты - способы продуктивных действий в данном возрасте представляют собой спектр компетенций, необходимых для осознанного построения индивидуальной образовательной траектории на последующих ступенях непрерывного образования как индивидуального проекта самого учащегося. Совокупность таких компетенций образует собой системное личностное качество учащегося, которое можно охарактеризовать как новую ступень его образовательной самостоятельности. Данное качество проявляется в готовности учащегося к реализации авторского проекта, включая постановку конкретных дальних и ближних целей своего образовательного продвижения, определение средств и ресурсов их достижения, а также деловое сотрудничество с другими людьми - представителями внешнего социального окружения.

Деловое сотрудничество также образует основу достижения третьего вида индивидуальных образовательных результатов - способов социального утверждения собственной продуктивной деятельности. В ранней юности, в отличие от подросткового периода взросления, это утверждение уже может осуществляться не только в модельных, но и реальных социально укорененных формах. Наиболее эффективной может выступать форма общественной защиты индивидуального проекта, проводимой при участии представителей различных социальных институтов и профессиональных сообществ. Не исключено также включение в процедуры защиты широкой зрительской аудитории, в том числе в современных форматах, таких как ScienceSlam. Сами же индивидуальные образовательные результаты учащихся представляют собой широкий спектр способов сотрудничества и продуктивных коммуникаций с различными людьми, занимающими по- 
зиции субъектов внешней оценки проектной деятельности учащихся.

В заключение следует отметить, что предложенные здесь понимание и возрастная периодизация индивидуальных образовательных результатов учащихся может стать основой для разработки новых моделей преемственности различных образовательных систем (ДОУ, школы, вуза) на общих методологических основаниях индивидуализации образовательного процесса. В тоже время необходимо признать, что в условиях традиционных, не индивидуализированных моделей образования их достижение существенно осложнено. Именно поэтому в нашем исследовании мы, в первую очередь, рассматриваем возможности учреждений дополнительного образования детей, перед которыми в этой связи ставятся новые задачи их развития, соответствующие специфическим требованиям современной действительности.

1.4. Особенности индивидуальных образовательных результатов учащихся в системе дополнительного образования

Индивидуализированный характер дополнительного образования и его направленность на удовлетворение индивидуальных образовательных потребностей учащихся отмечается в большинстве современных исследований (В.В. Абраухова, А.И. Адамский, А.Г. Асмолов, М.И. Болотова, О.С. Бондарева, Т.В. Гильмидинова, И.А. Зимняя, А.В. Леонтович, С.В. Лобынцева, Л.Г. Логинова, Н.В. Саяпин, М.Н. Филатова, Г.А. Яшина и др.). Эта сфера педагогической деятельности выступает для исследователей компонентом образования личности как субъекта своего внутреннего роста, самоопределения и саморазвития индиви- 
дуальности [20], важнейшей подсистемой непрерывного образования [62].

Индивидуальная направленность дополнительного образования как сущностная характеристика, отличающая его от общеобразовательной школы, доказана и в современных экспериментальных исследованиях, на основании которых сделан вывод о том, что «посещение кружков и секций положительно сказывается на процессе социализации подростка и его профессиональном самоопределении» [89, с. 92].

В то же время не вполне прояснено, что именно должно выступать системообразующим элементом педагогической системы дополнительного образования, обеспечивающим развитие индивидуальности учащихся как универсальной способности к самосотворению своего Я в процессе творческого взаимодействия с окружающей социокультурной средой. Наше исследование базируется на предположении о том, что в роли такого системообразующего элемента могут выступать индивидуальные образовательные результаты учащихся, проектирование и оценка которых составляет «ядро» совместной деятельности педагогов и учащихся. Обоснованию этого тезиса посвящен настоящий параграф.

Решая поставленную задачу, мы проанализировали тексты научных публикаций по проблеме индивидуализации дополнительного образования, выделяя при этом различные подходы к пониманию сути этого явления. На основе полученных данных мы охарактеризовали индивидуальные образовательные результаты учащихся как компонент педагогической системы, проектируемой на основе принципа индивидуализации образования.

Проведенный анализ позволил установить, что сущность индивидуализации процесса дополнительного образования понимается современными исследователями в 
широком и узком контекстах. В самом широком выражении сущность индивидуализации связана с тем, что «ценностно-смысловое ядро дополнительного образования заключено в его гуманистической основе, развитии ребенка во времени по отношению к самому себе и к окружающему миру» [20, с. 21]. Идея роста ребенка над самим собой выступает главным методологическим основанием проектирования современных индивидуализированных систем и профессионального развития педагогов дополнительного образования.

В работах И.В. Ивановой и Л.Г. Логиновой сущность дополнительного образования характеризуется как «самоосуществление, самосозидание каждым ребенком собственной индивидуальности». Как отмечают авторы, «при этом развитие личности представляет собой не линейный процесс развертывания природного дара, а многоплановый и целостный способ жизни человека...». С этой точки зрения назначение дополнительного образования состоит в «психолого-педагогической поддержке самообразования, самовоспитания, самодеятельности человека» [31].

В таком контексте складываются представления об индивидуализации дополнительного образования как о стратегии, основанной на выстраивании индивидуальных образовательных маршрутов учащихся. Как, в частности, отмечает по этому поводу Л.М. Митрофанова, индивидуализация «осуществляется как организация мотивированного взаимодействия педагогов и детей в рамках ситуаций множественного выбора, педагогической поддержки и взаимопомощи детей. Это предполагает установление гуманистических взаимоотношений, анализ вместе с ребенком результатов диагностики и их использование при разработке его индивидуальных образовательных траекторий и индивидуальных образовательных маршрутов» $[64$, с. 98]. 
В то же время существует и более узкий контекст понимания данного феномена как характеристики содержания образования, строящегося с учетом индивидуальных особенностей ребенка. Так, по утверждению Н.И. Гусляковой и Т.В. Садыковой, «индивидуализация - как признание индивидуальных различий - осуществляется в вариативности дополнительных образовательных программ» [24].

Следует отметить, что эти два контекста изучения индивидуальных образовательных результатов учащихся как педагогического феномена имеют принципиальное различие, в силу чего не могут быть сведены друг к другу. В первом случае речь идет о системных и даже глобальных новообразованиях личности, формирование которых выступает результатом творческой, преобразовательной деятельности самого субъекта. Таким образом, индивидуальные образовательные результаты мыслятся как достижения самого учащегося. Они могут быть проинтерпретированы как его собственные открытия, совершаемые в ходе решения проблемных смысложизненных задач. Экстраполируемые непосредственно в сферу учебнопознавательной деятельности, эти результаты носят характер открытых учащимся смыслов и способов действий, приводящих к таким открытиям. Примером может служить открытый (после долгих мучений) ребенком способ узнавать время при помощи настенных часов. Предшествующие объяснения, получаемые от взрослых, не помогали ему освоить такое действие, они накапливались подспудно и не «превращались» в результат, однако в момент озарения он все же сделал это открытие самостоятельно [17]. Эти открытия переживаются ребенком эмоционально. Полученное таким путем знание, как отмечает В.П. Зинченко, является для ученика не просто знанием, а событием знания [30]. 
Во втором случае (узкий контекст) субъектность ученика ограничена формальным выбором из числа предлагаемых альтернатив (вариативных учебных программ). При этом сами образовательные результаты уже заложены в этих программах и рассчитаны на усвоение всеми учащимися, выбравшими их по своим интересам и склонностям. «Индивидуальность» этих результатов ограничена здесь всего лишь степенью полноты и уровнем освоения самой программы.

Проведенный анализ литературы также позволяет утверждать, что в основе индивидуализации дополнительного образования существует противоречие между стремлением педагога видеть в ученике субъекта самосотворения, личностного и профессионального самоопределения и внешней запрограммированностью тех реальных образовательных результатов, на достижение которых направлена образовательная программа.

Для прояснения этой ситуации нами были выделены основные различия между «обычными» (запрограммированными) образовательными результатами освоения программы и индивидуальными образовательными результатами как собственными шагами образовательного продвижения ученика, то есть его открытиями, совершаемыми в процессе решения проблемных задач. Результаты этой работы представлены в таблице 1.2.

Таблица 1.2. Сравнительные характеристики общих и индивидуальных образовательных результатов учащихся

\begin{tabular}{|l|l|l|}
\hline $\begin{array}{c}\text { Позиции срав- } \\
\text { нения }\end{array}$ & Общий результат & $\begin{array}{l}\text { Индивидуальный } \\
\text { результат }\end{array}$ \\
\hline $\begin{array}{l}\text { Целевая } \\
\text { направленность }\end{array}$ & $\begin{array}{l}\text { Усвоение норм и и } \\
\text { общепринятых } \\
\text { 3начений объек- } \\
\text { тов и явлений }\end{array}$ & $\begin{array}{l}\text { Опредение ин- } \\
\text { дивидуального } \\
\text { шеносового отно- объектам }\end{array}$ \\
\hline
\end{tabular}




\begin{tabular}{|c|c|c|}
\hline & $\begin{array}{l}\text { окружающей дей- } \\
\text { ствительности }\end{array}$ & $\begin{array}{l}\text { и явлениям окру- } \\
\text { жающей действи- } \\
\text { тельности }\end{array}$ \\
\hline $\begin{array}{l}\text { Источник фор- } \\
\text { мирования }\end{array}$ & $\begin{array}{l}\text { Достигается в } \\
\text { процессе изучения } \\
\text { и репродукция го- } \\
\text { тового учебного } \\
\text { материала }\end{array}$ & $\begin{array}{l}\text { Достигается в про- } \\
\text { цессе творческого } \\
\text { освоения социо- } \\
\text { культурных прак- } \\
\text { тик }\end{array}$ \\
\hline $\begin{array}{l}\text { Необходимые } \\
\text { средовые усло- } \\
\text { вия }\end{array}$ & $\begin{array}{lr}\text { Достигается } & \text { в } \\
\text { формальной } & \text { (дог- } \\
\text { матической) обра- } \\
\text { зовательной среде }\end{array}$ & $\begin{array}{l}\text { Достигается в не- } \\
\text { формальной } \\
\text { (творческой) обра- } \\
\text { зовательной среде }\end{array}$ \\
\hline Способ оценки & $\begin{array}{l}\text { Контроль соот- } \\
\text { ветствия задан- } \\
\text { ному эталону }\end{array}$ & $\begin{array}{l}\text { Экспертное оцени- } \\
\text { вание }\end{array}$ \\
\hline $\begin{array}{l}\text { Эмоционально- } \\
\text { ценностное от- } \\
\text { ношение со сто- } \\
\text { роны } \\
\text { ученика }\end{array}$ & $\begin{array}{l}\text { Воспринимается } \\
\text { как выполненное } \\
\text { внешнее требова- } \\
\text { ние }\end{array}$ & $\begin{array}{l}\text { Достижение ре- } \\
\text { зультата эмоцио- } \\
\text { нально пережива- } \\
\text { ется учеником как } \\
\text { значимое событие }\end{array}$ \\
\hline
\end{tabular}

Источник: составлено соавторами монографии.

Source: compiled by the co-authors of the monograph.

Из проведенного сравнительного анализа можно заключить, что индивидуализированный (то есть, ориентированный на достижение учащимися индивидуальных образовательных результатов) процесс должен строиться на существенно иных основаниях. Так, в «обычном» процессе, ориентированном на общие образовательные результаты для всех учащихся, целью деятельности педагогов выступает трансляция единых для всех значений объектов и явлений окружающего мира. Это обусловливает необходимость полной определенности ситуации, в которой осуществляется такая трансляция. Необходимо точно знать заранее, что именно и в каком виде должно отра- 
зиться в сознании учащихся, какие нормы и знания они усвоят, какие «правильные» действия научатся выполнять. Образовательный процесс в этом случае разворачивается от педагога к учащимся, собственная творческая активность ученика вторична по отношению к действиям педагога. Любые субъектные проявления учащихся, будь то найденный отличный от предъявленного образца способ решения учебной задачи, самостоятельно сделанный оригинальный вывод, не совпадающий с «правильным» пониманием изучаемого материала, нежелательны. Даже если педагог и «поддерживает» такие проявления активности учеников, все равно они не являются самодостаточными и не должны искажать заданную учебную ситуацию. Напротив, достижение учащимися индивидуальных образовательных результатов предполагает выстраивание ими собственного смыслового отношения к познаваемым объектам и явлениям. По утверждению В.П. Зинченко, «недостаточно, чтобы ребенок усвоил значение данного предмета, безразлично теоретическое или практическое, но нужно, чтобы он соответственно отнесся к изучаемому, нужно воспитать у него требуемое отношение» [30, с. 35]. Для этого ситуация решения творческой задачи должна обладать достаточно высоким уровнем неопределенности, то есть допускать возможность принятия различных решений и различных способов осмысления учащимися заложенной в ней (задаче) культурной проблематики. Субъектная активность учащегося выступает в этом случае необходимым условием достижения таких образовательных результатов.

Существенно различны и источники происхождения общих и индивидуальных образовательных результатов учащихся. В «обычной» модели образовательного процесса таковым источником служит заранее подготовленный, 
адаптированный к наличным познавательным возможностям ученика учебный материал. Для нашего анализа важно то, что этот материал не совпадает с содержаниями окружающей познающего субъекта действительности, поскольку он уже «просеян» сквозь сито «правильных» толкований и интерпретаций и не предполагает возможности его творческого преобразования. В модели индивидуализированного образовательного процесса учебный материал уже не может служить для учащихся главным источников образовательных результатов. На материале «готового», завершенного в своем развитии знания, субъект не обладает возможностью выстраивать к этому знанию собственное смысловое отношение. Для этого необходимы другие источники, которые достаточно часто исследователи называют «социокультурные практики» (анализ этого понятия ранее был осуществлен нами в [32]). В отличие от «обычного» учебного материала, проектируемая как единица индивидуального образовательного маршрута учащегося социокультурная практика содержит в себе возможности ее творческого преобразования, поскольку сохраняет в содержании познаваемых объектов и явлений их культурную проблематику. Другими словами, социокультурная практика запечатляет в себе проблемные задачи, процесс решения которых в Культуре еще не завершен. (По этому поводу уместно вспомнить высказывание философа и писателя А. Зиновьева: есть вечные вопросы, но нет вечных ответов.)

Поэтому деятельность учащихся, направленная на творческое освоение социокультурных практик, осуществляется путем совершения проб. Отметим, что именно сфера дополнительного образования имеет возможность организации таких разнообразных проб в различных сферах социально ориентированной деятельности. 
Такими пробами могут выступать игры (для детей дошкольного возраста), выполнение творческих заданий (для более старших), а также проведение пилотных исследований с использованием специальных методов (наблюдение, анализ, моделирование и т.д.). Например, приглашая детей в мир народного танца, педагог дополнительного образования может смоделировать в игровой форме исторические события и ситуации, которые отражаются в танцевальном искусстве. В ходе моделирования таких ситуаций можно предложить детям перевоплотиться в их героев, в героев прошлых времен, используя для этого выразительные средства движений тела. После этого можно соотнести собственное решение с культурными аналогами, т.е. посмотреть, как это делается «понастоящему». Крайне важно, чтобы собственная проба ребенка предшествовала прямой демонстрации таких культурных аналогов.

В другом случае (творческие объединения естественнонаучной направленности) формами таких проб могут быть проведение лабораторных опытов или же просто наблюдение за объектами живой и неживой природы.

В целом, речь идет о создании модельных ситуаций, в которых учащимся необходимо совершать продуктивные действия, результатом чего становится осмысление предлагаемых социокультурных практик как источников новых возможностей для самих учащихся.

Третье различение общих и индивидуальных образовательных результатов связано с особенностями образовательных сред, в условиях которых достигаются эти результаты. Общие образовательные результаты успешнее всего формируются в жестко нормированной формальной (догматичной) образовательной среде. Этому способствует единообразие требований и информацион- 
ных ресурсов, фиксированные профессиональные позиции педагогов, деятельностных схем и т.д. Именно формализованный характер среды выступает необходимым условием достижения единых образовательных результатов, заложенных в реализуемые образовательные программы.

Индивидуальные образовательные результаты могут достигаться учащимися только в условиях неформальной (творческой) образовательной среды, представляющей собой гибкую, динамичную систему взаимодействий различных субъектов образовательного процесса. Для этого типа среды характерны продуктивные действия и продуктивные коммуникации, осуществляемые субъектами этих действий в процессе совместного решения творческих задач. Данный тип среды отличается множественностью реализуемых социально-ролевых позиций участников совместной творческой деятельности. Все эти характеристики в наибольшей степени присущи именно сфере дополнительного образования детей, где представлен весьма широкий спектр разнотипных творческих объединений, в условиях которых могут осуществляться продуктивные коммуникации между детьми и взрослыми.

Различия между общими и индивидуальными образовательными результатами проявляются и в системе их оценки. Единые для всех образовательные результаты рассчитаны на контрольные процедуры оценивания на основе установления степени соответствия достигнутого уровня освоения программы заданным нормативным требованиям. Любое расхождение того, что предъявляет учащийся как свое индивидуальное достижение, и заданной норме здесь расценивается как недочет, снижающий общую оценку его деятельности. Именно таким образом используются все контрольные проверочные работы, 
ориентированные на оценку в системе координат «верно не верно».

Индивидуальные образовательные результаты могут быть оценены на основе экспертных методов как степень достигнутого соответствия между образовательными потребностями конкретного ребенка и степенью их удовлетворенности в образовательном процессе. Предметом оценивания выступает состоявшийся в ходе освоения социокультурной практики шаг продвижения ученика по его индивидуальной образовательной траектории. При этом должны учитываться, как особенности социальной образовательной ситуации учащегося, так и его собственные социальные притязания, связанные с совершением этого шага. Выше мы выделили три уровня социальных притязаний ученика как субъекта построения индивидуальной образовательной траектории: уровень свободной социальной пробы; социально-адаптационный и ценностно-смысловой уровни. Необходимым условием оценки индивидуальных образовательных результатов выступает проектирование оценочных процедур как образовательных событий, в ходе которых создаются ситуации личностной рефлексии учащихся и осваивается ими позиция субъектов оценивания собственных образовательных достижений.

И завершающей позицией предпринятого нами сравнительного анализа общих и индивидуальных образовательных результатов выступает отношение к этим результатам самих учащихся. Речь идет о том, каково субъективное значение достигаемых образовательных результатов для субъекта образовательной деятельности. Сформированность такого отношения выступает главным индикатором, свидетельствующим о том, являются ли достигаемые образовательные результаты подлинно индивидуальными. В упомянутой работе В.П. Зинченко отмеча- 
ется, что «сознание есть не только знание, но и аффективное отношение» [30, с. 34]. «Живое знание», являясь именно индивидуальным образовательным результатом воспринимается учащимся эмоционально, внутреннее «озарение», которым сопровождается открытие, есть не что иное, как объективное подтверждение того, что оно (открытие) действительно состоялось. В то же время эмоциональное отношение к общим образовательным результатам, достижение которых запрограммировано заранее, не является свидетельством обнаружения учеником собственного смысла, поэтому оно в лучшем случае может носить характер «чувства удовлетворения», которое он получает только лишь от того, что задание, данное учителем, выполнено верно.

Из сказанного в этом параграфе можно заключить, что практически по всем позициям сравнительного анализа общих и индивидуальных образовательных результатов современная система дополнительного образования детей имеет неоспоримо большие возможности индивидуализации образовательного процесса, нежели общеобразовательная школа. Однако для того чтобы реализовать эти возможности в полной мере необходимо решить ряд проектных задач, а именно: разработать и внедрить в образовательный процесс учреждения дополнительного образования технологии проектирования разнообразных социокультурных практик, отвечающих широком спектру интересов и склонностей детей с учетом из возрастных особенностей; разработать модель продуктивных коммуникаций между учащимися и педагогами дополнительного образования в их совместной творческой деятельности; разработать интерактивную модель оценки индивидуальных образовательных результатов учащихся на основе принципов формирующего оценивания и событийности. Подробнее речь об этой пойдет в следующих главах. 


\section{Выводы по первой главе}

Проблема проектирования индивидуальных образовательных результатов возникает на разрыве между современными представлениями об индивидуализации образования и укорененными взглядами на образовательные результаты как на усваиваемые в процессе обучения единые для всех учащихся знания, нормы и способы действий. Она органично вписывается в контекст новейших реалий развития цивилизации, таких как динамичность происходящих изменений, вариативность и многообразие мира, необходимость поиска достойных ответов на «вызовы будущего».

Индивидуальные образовательные результаты учащихся могут пониматься как совершаемые на достаточно высоком уровне образовательной самостоятельности шаги продвижения по индивидуальной образовательной траектории, в процессе которого ими обретаются новые смыслы проблематизированных содержаний Культуры, способы творческого освоения этих содержаний и социального утверждения собственной деятельности во взаимодействии с другими людьми. На каждом возрастном этапе онтогенеза ребенка эти результаты имеют свои специфические особенности, обусловленные социальной ситуацией и характеристиками ведущей деятельности развития.

Современная система дополнительного образования детей обладает большими возможностями реализации инновационных моделей индивидуализации образовательного процесса, которые мало доступны для образовательных систем общего образования. Проектирование, научное обоснование и внедрение этих моделей представляют собой актуальное направление развития системы дополнительного образования, отвечающее трендам современной образовательной политики. 


\section{2. Проектирование индивидуальных образовательных результатов как совместная деятельность учащихся и педагогов дополнительного образования}

\section{1. Современная практика полагания и оценки ин-}

дивидуальных образовательных результатов учащихся

Полагание и оценка образовательных результатов выступает неотъемлемой частью целостного образовательного процесса. Однако вполне естественно возникает вопрос о субъектах этой деятельности. В традиционных педагогических теориях, последовательно развивавшихся на протяжении последних десятилетий, эта деятельность являлась прерогативой педагога, по отношению к которой собственная активность ученика в выборе целей и самооценке достигаемых результатов являлась вторичной. Несмотря на то что исследователи всецело признавали необходимость активного участия учащихся в решении познавательных задач, выдвижение и постановка этих задач представляло собой неотъемлемый компонент профессиональной деятельности педагога. Так, например, в широко известной в 60-е - 70-е годы прошлого столетия работе коллектива ученых под руководством М.А. Данилова и М.Н. Скаткина отмечалось: «Искусство учителя заключается в том, чтобы, вооружая знаниями учащихся, последовательно подводить их ко все более усложняющимся задачам и в то же время подготовлять к выполнению этих задач, с таким, однако, расчетом, чтобы выполнение каждой новой задачи требовало от учащихся ровно столько самостоятельного труда и напряжения мысли, сколько могут проявить они при учете их возрастных и индивидуальных различий в данных условиях обучения» [27, с. 93]. 
Получившее в исследованиях последнего времени понимание ученика как субъекта построения своей собственной образовательной траектории лежит в основе принципа индивидуализации образования, суть которого может быть определена как создание условий осознанного выбора каждым учеником индивидуальной образовательной траектории, приводящей его к максимуму развития собственного творческого потенциала [40; 41]. Индивидуальная образовательная траектория рассматривается как авторский проект самого ученика, реализуемый им в открытом, вариативном образовательном пространстве в условиях избытка возможностей и ресурсов удовлетворения персональных образовательных потребностей. В этой ситуации возникают качественно новые требования к уровню субъектности ученика, реализуемой им в образовательном процессе. Этот уровень должен обеспечивать ученику возможность деятельностно осваивать разнообразные социальные и культурные практики, выступающие для него источником обретения новых преобразовательных средств в динамично изменяющейся действительности. Последовательность этих практик не регламентирована внешне заданной образовательной программой, только таким путем может быть осуществлен современный принцип «образование через всю жизнь».

Кроме того, необходимо учесть и то обстоятельство, что освоение разнообразных социокультурных практик происходит посредством разных видов деятельности субъекта, которые, будучи образовательными по своей сути, в то же время не сводятся к собственно учебной, направленной исключительно на усвоение учебного материала. Современные модели образования ориентируют учащихся, в первую очередь, на развитие продуктивной деятельности, посредством которой окружающий мир по- 
знается субъектом не статично, а в процессе его творческого преобразования. Именно этот подход заложен, в частности, в основу концепции подростковой школы, разработанной творческим коллективом ученых и педагоговпрактиков под руководством Б.Д. Эльконина [47].

Однако было бы ошибочным считать, что полномочия субъекта целеполагания и оценки индивидуальных образовательных результатов могут быть формально делегированы ученику, поскольку это не меняет общего смысла оценки как установления соответствия реально достигнутого результата внешне заданному требованию. Главной функцией оценки должна стать регуляция процесса продвижения субъекта по индивидуальной образовательной траектории, а для этого необходимо учитывать, что именно оценка является системообразующей функцией психики субъекта. В психологических исследованиях, в частности, показано, что субъективная (то есть, осуществляемая самим субъектом) оценка деятельности «ответственна» не только за достижение социально значимых результатов, но и за формирование мотивов этой деятельности. Как отмечает в своем исследовании А.А. Понукалин, «субъективная полезность то или иной деятельности устанавливается в непроизвольном и произвольном оценивании ее характеристик, становится основой формирования мотивообразования этой деятельности» [76, с. 22].

В этой логике целеполагание и оценка образовательных результатов должны быть интегрированы в образовательную деятельность учащихся как ее неотъемлемый структурный компонент. В свою очередь, это требует преобразования всей педагогической системы и, в частности, изменения ее методической базы и профессиональноролевых позиций педагогов. 
В нашем исследовании в данной связи изучались особенности целеполагания и оценки результатов учащихся в учреждениях дополнительного образования детей. Именно дополнительное образование, начиная еще с 90-х годов прошлого столетия, воспринимается в общественно-педагогическом сознании как «сфера наибольшего благоприятствования» для развития личности каждого ребенка [7]. В современных исследованиях процессов развития этой сферы отмечается, что «важным аспектом здесь выступает установка на развитие «субъектности» обучающегося, а это, в свою очередь, предполагает особый характер организации самого педагогического процесса как субъектно ориентированного» $[88$, с. 44]. В этой связи мы предположили, что в современной практике дополнительного образования детей могут быть обнаружены новые модели целеполагания и оценки индивидуальных образовательных результатов учащихся, реализуемые в логике проектирования индивидуальной образовательной траектории ученика как его авторского проекта.

В ходе исследования был применен метод семантического анализа литературы (публикаций, методических рекомендаций, дополнительных образовательных программ и иных материалов, характеризующих деятельность учреждений дополнительного образования) и метод опроса. В первом случае (семантический анализ текстов) нас интересовали понятия, при помощи которых характеризуются образовательные результаты учащихся на этапах их полагания и оценки. Мы исходили из того, что в современной практике образования укоренены три основных способа понимания образовательных результатов: 1) как усвоенной нормы; 2) как освоенного способа действий; 3) как обретенной новой возможности дальнейшего образовательного продвижения. (В наших пред- 
шествующих исследований мы показали связь этих способов понимания образовательных результатов с тремя типами культур по М. Мид [33].) Мы предположили, что используемые в текстах характеристики целей и результатов образовательного процесса могут быть проинтерпретированы с точки зрения выделенных способов их понимания на основании фиксации используемой авторами терминологии. Таким путем были проанализированы более 30 различных текстов, размещенных в периодической печати и на сайтах образовательных организаций и методических служб.

Во втором случае (опрос педагогов дополнительного образования) использовалась анкета жесткого типа, включающая пять основных и три вспомогательных вопроса. Основные вопросы были направлены на выявление: 1) реальных субъектов, которые, по мнению опрошенных педагогов, осуществляют полагание образовательных результатов учащихся; 2) источников представлений педагогов о том, каковы должны быть результаты обучающихся в процессе дополнительного образования; 3) распространенных среди педагогов представлений о сущности понятия «образовательный результат»; 4) типичных затруднений педагогов, связанных с полаганием образовательных результатов учащихся. Кроме того, методом ранжирования ответов изучались критерии качества образовательных результатов учащихся, на которые ориентируются педагоги дополнительного образования в своей практической деятельности. К каждому вопросу предлагались ответы, спектр которых отражал смысловые характеристики указанных выше способов понимания сути образовательного результата. Проведенное исследование позволило получить следующие данные. 
Как было сказано, ориентация педагогов дополнительного образования, методистов, руководителей и др. лиц, причастных к процессам целеполагания и оценки персональных образовательных достижений учащихся, на конкретный вид образовательных результатов проявляется, в том числе, в использовании ими определенных понятий и терминологии. Так, ориентация на образовательный результат как на усвоенную учащимися норму чаще всего связана с такими понятиями и словосочетаниями, как «ученик будет знать», «ученик будет уметь», «ученик усвоит», «ученик будет иметь представление», «получит навыки» и другими, сходными по смыслу. Отметим, что «смысловое ядро» этих семантических конструкций состоит в указании на усвоение учеником, тех содержаний, которые уже существуют в «готовом» виде и не подлежат творческому преобразованию со стороны субъекта. Его деятельность состоит только в том, что он «усваивает» или, в более мягком выражении, «ознакомляется» с этими содержаниями. Даже указание на то, что «ученик будет уметь», не выходит за рамки усвоения того, что уже известно заранее. Ведь умение в этой логике есть ничто иное как способность воспроизводить действия и операции в заранее известной ситуации вне контекста решения оригинальной, творческой задачи (в противном случае используется другая терминология, о чем речь пойдет далее).

Ориентация на образовательный результат как на способ действия, необходимый для самостоятельного решения субъектом задачи, чаще всего предполагает использование языка компетентностного подхода. В современных исследованиях получила распространение точка зрения, согласно которой понятие компетентности связано с различением репродуктивной и продуктивной дея- 
тельности субъекта. Так, группой авторов под научным руководством А.А. Попова обосновано следующее различение. Репродуктивная деятельность - это деятельность по заданному образцу. Для ее осуществления необходимы т.н. репродуктивные компетенции, связанные с освоением и применением такого образца в определенных условиях. В отличие от нее, продуктивная деятельность - это деятельность без образца, может представлять собой как деятельность по созданию нового образца, так и действия в заведомо уникальной ситуации... Связанные с ней компетенции имеют более рефлексивный и антропологический культурный характер и основаны на «самости», экзистенциальной основе любой субъектности» [77, с. 53].

По мнению авторов, настоящий момент развития образования в России характеризуется тем, что общее образование, в основном, ориентировано на формирований у учащихся репродуктивных компетенций, в то время как дополнительное образование усиливает акцент на развитии продуктивных компетенций, характеризуемых более выраженной рефлексивностью и субъектностью учащихся. Исходя из этого, авторы приводят перечень базовых компетенций, анализ которых позволяет выделить основные семантические единицы - способность и готовность. К таковым компетенциям авторы относят: аналитическую, проектную, компетенцию самоорганизации и соорганизации, коммуникативную, креативную, а также способность отвечать за свои слова и поступки [77, с.55]. Характерно, что в интерпретации авторов категории «способность» и «готовность» не только характеризуют компетенцию как образовательный результат, но и задают два главных параметра этого результата. Так, способность определяется авторами как «владение способом деятельности, а в развитой форме - порождение способов в соот- 
ветствии с конкретными ситуациями и задачами». Готовность же определяется как «экзистенциальная характеристика, интегрирующая в себя волю, способность ставить и удерживать цель, психофизический базис, позволяющий начинать действовать и стремиться к достижению цели» [77, с.57].

И, наконец, третий, выделенный нами способ понимания сущности образовательного результата как обретаемой ребенком возможности может быть проинтерпретирован в контексте идей развивающего образования. Базовым основанием выступает здесь учение Л.С. Выготского о зоне ближайшего развития. Отметим, что и в упомянутой работе коллектива ученых под руководством А.А. Попова понятия возможности также присутствует, однако, оно интерпретируется в рамках избранного компетентностного подхода как «сквозная компетенция». При этом авторы опираются на дефиницию, предложенную Ю.В. Громыко и В.В. Давыдовым: «Сквозные компетенции - это возможности, которыми обладают люди для включения в современные формы мышления, деятельности, кооперации и коммуникации и на которые можно рассчитывать при постановке и решении масштабных задач, связанных в том числе и с территориальным развитием» [77, с. 56]. По мнению авторов, возможность представляет собой высший уровень компетенции, выступая при этом «управляющей инстанцией» по отношению к компетенциям более низкого уровня, таким как способности. Авторы выделяют три наиболее актуальных вида возможностей: возможность движения за рынками труда, возможность самоидентичности и возможность социальной коммуникации. Наиболее важной характеристикой возможности в этом смысле выступает ее обращенность в будущее, которое в социальной ситуации развития ребенка представляется 
весьма отдаленным. В контексте идеи Л.С. Выготского такое будущее представляет собой скорее зону «дальнего» нежели «ближайшего» развития.

В то же время логичнее было бы предположить, что индивидуальные образовательные результаты ребенка, полагание и оценка которых осуществляется в процессе дополнительного образования должны относиться именно к зоне ближайшего развития и по своей сути представлять собой возможности самостоятельного решения творческих задач, которые в настоящий момент могут быть им решены только совместно со взрослыми (педагогами). В этом ключе обретение новых возможностей неразрывно связано с формированием предпосылок как новообразований психической сферы ребенка. В роли таких предпосылок безусловно могут выступать и сформированные способы действий, однако в русле теорий развивающего образования такие предпосылки характеризуются более широко. Так, например, в дошкольном детстве такой универсальной «коренной способностью» выступает развитое творческое воображение [55]. Именно на основе творческого воображения ребенок впоследствии осваивать способы умственных действий, позволяющие ему самостоятельно решать интеллектуальные задачи. Проведенный анализ позволил установить, ч то абсолютное большинство образовательных программ, реализуемых в сфере дополнительного образования детей ориентированы на достижение образовательных результатов первого вида, т.е. усвоение заданной нормы. Предельно четко эта ориентация прослеживается, к примеру, в методических рекомендациях по разработке программ дополнительного образования [80]. Несмотря на то, что авторы этих рекомендаций формально апеллируют к компетентностному подходу, данное ими определение («ожидаемый 
(прогнозируемый) результат - это конкретная характеристика знаний, умений и навыков, которыми овладеет обучающийся» [80, с. 25]) свидетельствует о понимании образовательного результата именно как об усвоенном ребенком внешне заданном содержании, а не как о способности самостоятельно решать творческие задачи.

Именно в таком ключе выполнены рекомендуемые варианты формулировок ожидаемых результатов, которые авторы подразделяют на две группы. В первую группу входят формулировки, характеризующие самого ребенка: «будет знать..., будет уметь..., будет иметь представление..., будет стремиться..., будет обучен..., овладеет понятиями..., получит навыки..., расширит представления..., научится делать...». Вторая группа формулировок говорит о том, что будет сформировано «у ребенка»: «будет сформирована устойчивая потребность..., будут воспитаны морально-волевые и нравственные качества; будет развита устойчивая потребность к самообразованию; будет сформирована активная жизненная позиция; будут развиты творческие способности; будет воспитано уважение к нормам коллективной жизни» [80, с. 48].

Весьма характерно, что связь между формулировками первой и второй группы носит исключительно гипотетический характер. Если за формулировками первой группы стоят конкретные усвоенные ребенком сведения и образцы, то формулировки второй группы выглядят скорее как благие намерения, нежели как реально достигаемый результат.

Вполне соответствуют такому взгляду на образовательные результаты и предлагаемые способы и формы их оценки, перечень которых включает в себя: «беседа, опрос, наблюдение; прослушивание на репетициях; праздничные мероприятия; выставки, фестивали; концерты; экзамены, 
зачеты; конкурсы, соревнования» [80, . 49]. Нетрудно заметить, что главными субъектами оценки этих образовательных результатов, осуществляемых на основе предложенных методов и форм, выступают педагоги, роль ребенка в этом процессе практически не просматривается. Кроме того крайне важно то обстоятельство, что оценка образовательных результатов в данном виде носит чисто внешний, «контролирующий» характер и не интегрирована в содержание деятельности самих учащихся как таковой. Однако именно в таком ключе разработано абсолютное большинство проанализированных нами программ дополнительного образования детей.

Второй выделенный нами способ понимания образовательного результата (как освоенного способа действий в русле компетентностного подхода) представлен в практике современного дополнительного образования детей значительно реже. Среди изученных нами материалов он представлен в виде инновационных моделей летних образовательных лагерей. Так, в модели, предложенной А.А. Поповым, реализуется модульный принцип обучения и оценки индивидуальных образовательных результатов учащихся. В рамках реализуемых модулей осуществляются и оцениваются два типа работ: работа в тематической группе и во время общей дискуссии. В первом случае (работа в тематической группе) предметом оценивания выступает: содержательный вклад ученика в работу группы, мыследеятельностная активность, качество выполнения отдельных функции в коллективно-распределенной работе, в отдельных случаях, лидерские способности [78]. На этом этапе субъектом оценивания выступает педагог, который оценивает содержательное качество доклада, т.е. работу всей группы. Предлагается использование балльной системы оценки. 
На общей дискуссии оценивается работа выступающих учеников. Предметом оценки, также осуществляемой педагогом, выступают их ораторские способности, уровень понимания того, о чем говорит выступающий, а также за ответы на вопросы, как от самого учителя, так и от аудитории.

Модель также предусматривает такие формы оценивания, как круглый стол, индивидуальную работу и оформление электронной карты своего самоопределения и жизнедеятельности. Большое значение имеет индивидуальная работа учеников, в ходе которой предметом оценивания становятся собственные представления учащихся по поводу их дальнейшей перспективы и «встраивания» осуществляемой деятельности в более широкие социальные и профессиональные контексты. Нетрудно заметить, что в данном случае уже проявляется роль самого ученика как субъекта полагания и оценки собственных образовательных результатов. Имеет также место попытка проецирования наличной образовательной ситуации в перспективное будущее. Однако как было сказано, это будущее рассматривается как весьма отдаленная перспектива, что затрудняет процесс проектирования учениками ближайших этапов индивидуальной образовательной траектории.

Несколько иной подход представлен в образовательной программе ВДЦ «Артек», где методы полагания и оценки образовательных результатов учащихся, отвечающие принципам компетентностного подхода, в большей степени соответствуют методологии, представленной в федеральных государственных образовательных стандартов общего образования. в частности образовательные результаты учащихся разделяются на личностные, предметные и метапредметные. Однако отличной «школьной» 
идеологии разработчик программы в качестве главного методологического основания указывают на единство этих трех видов результатов: «объективно личностные, метапредметные и предметные результаты не могут быть отделены друг от друга и представляют триединую задачу современного образования» [70, с.15]. сущность образовательного результата здесь также раскрывается через категорию «опыт». Согласно авторской концепции, социокультурный опыт представляет собой «освоенные действия по приобретению опыта в учебно-познавательной и разнообразной творческой деятельности» [70, с. 15]. Именно с этих позиций проинтерпретированы личностные, метапредметные и предметные образовательные результаты, а также предложены способы их фиксации и оценки. Большое значение придается интенсивности накопления учащимися позитивного социокультурного опыта, что рассматривается как главный показатель эффективности образовательной программы. Предложенный авторами подход характеризуется двойственностью оценки образовательных результатов. С одной стороны, эта оценка осуществляется в обычной логике компетентностного подхода, которая в сущности не отличается от описанной выше модели. Но при этом добавляется еще один блок оценки, связанный с определением степени удовлетворенности этими результатами самих учащихся. В этом можно увидеть существенный шаг к повышению уровня субъектности учащихся в оценке их собственных образовательных результатов. Однако вопрос об их субъектности в полагании этих результатов и определения к ним своего индивидуального отношения остается открытым.

Другой выделенный нами способ понимания сущности образовательного результата - обретаемой ребенком 
новой возможности, может быть проинтерпретирован в контексте идей развивающего образования. Отметим, что и в упомянутой работе коллектива ученых под руководством А.А. Попова понятия возможности также присутствует, однако, оно интерпретируется как некоторая «сквозная компетенция». При этом авторы опираются на дефиницию, предложенную Ю.В. Громыко и В.В. Давыдовым: «сквозные компетенции - это возможности, которыми обладают люди для включения в современные формы мышления, деятельности, кооперации и коммуникации и на которые можно рассчитывать при постановке и решении масштабных задач, связанных в том числе и с территориальным развитием» [77, с. 56]. По мнению авторов, возможность представляет собой высший уровень компетенции, выступая при этом «управляющей инстанцией» по отношению к компетенциям более низкого уровня, таким как способности. Авторы выделяют три наиболее актуальных вида возможностей: возможность движения за рынками труда, возможность самоидентичности и возможность социальной коммуникации. Наиболее важной характеристикой возможности в этом смысле выступает ее обращенность в будущее, которое в социальной ситуации развития ребенка представляется весьма отдаленным.

В то же время логичнее было бы предположить, что индивидуальные образовательные результаты ребенка, полагание и оценка которых осуществляется в процессе дополнительного образования, должны относиться именно к зоне ближайшего развития и по своей сути представлять собой возможности самостоятельного решения творческих задач, которые в настоящий момент могут быть им решены только совместно со взрослыми (педагогами). В этом ключе обретение новых возможностей будет 
неразрывно связано с формированием предпосылок как новообразований психической сферы ребенка. В роли таких предпосылок могут выступать и сформированные способы действий, однако в русле теорий развивающего образования такие предпосылки характеризуются более широко. Так, например, в дошкольном детстве такой универсальной способностью выступает развитое творческое воображение. Именно на основе творческого воображения ребенок впоследствии осваивать способы умственных действий, позволяющие ему самостоятельно решать интеллектуальные, творческие задачи [54].

Что же касается практик полагания и оценки индивидуальных образовательных результатов учащихся как обретаемых возможностей, реализация которых относится к зоне ближайшего развития ребенка, в предпринятом нами исследовании они выявлены не были, по крайней мере, непосредственно в сфере дополнительного образования детей. В то же время можно утверждать, что такой способ понимания сущности образовательного результата заложен в основу некоторых современных программ дошкольного образования. Так, например, в основу Примерной основной образовательной программы дошкольного образования «Тропинки» заложен подход, согласно которому роль показателей оценки образовательных результатов играют целевые ориентиры, представляющие собой «социально-нормативные возрастные характеристики возможных (курсив наш - В.И.) достижений ребенка на этапе завершения уровня дошкольного образования» [79, с. 103]. Характерно, что вопрос о возможных достижениях ребенка рассматривается авторами программы в контексте развития его субъектности, которая реализуется на этапе дошкольного детства 
в специфических формах инициативности, самостоятельности и ответственности.

Полученные данные проведенного анализа хорошо согласуются и с результатами опроса педагогов дополнительного образования, который проводился в учреждениях дополнительного образования гг. Сочи и Геленджик, Павловского района Краснодарского края и Тальменского района Алтайского края. Рассмотрим подробнее полученные результаты.

На вопрос «Кто, на Ваш взгляд, должен решать, чему именно должны научиться дети в Вашем творческом объединении?» более половины опрошенных педагогов (56 \%) указали «Самого ребенка в зависимости от собственных пожеланий и интересов»; 50,5 \% - ответили, что «Должен решать педагог на основе пожеланий родителей учащихся»; 40,5 \% - считают, что «Вопросы уже решены теми, кто разрабатывает образовательные программы, методические рекомендации и требования к работе образовательных учреждений». Треть педагогов (32,5 \%) отдают предпочтение решению данного вопросы внутри ученического (детского) коллектива совместно с педагогом; 23,4 \% - считают, что «Главные «заказчики» здесь родители учеников». Наименее предпочтительными ответами педагогов были такие как: «Это право принадлежит администрации моего образовательного учреждения» $(18,9$ \%); «Я и только Я» $(14,4$ \%). 2,7 \% педагогов затруднились ответить на данный вопрос.

При анализе ответов педагогов на вопрос «Откуда берутся Ваши представления о том, чему именно должны научиться у Вас Ваши ученики, что должно стать результатом посещения ими Вашего творческого объединения?» были получены следующие данные. Приоритетное количество (76,8 \%) педагогов «Обычно пытаются выяснить, 
каковы индивидуальные особенности самого ребенка, и что ему нужно для его собственного развития и решения своих жизненных проблем»; 59,5 \% «Учат тому, что сами хорошо знают и умеют». Также 39,6 \% опрошенных педагогов «Ищут обычно ответ на этот вопрос в специальной литературе, материалах, полученных на курсах повышения квалификации»; 30,7 \% - полагают, что «Для этого существуют требования руководства, нормативные документы и методические рекомендации, там все написано». Менее выбираемы педагогами такие ответы как: «Я исхожу из моих собственных представлений о том, что нужно человеку для успеха в современной жизни» (20,7%); «Обычно я ориентируюсь на опыт коллег, которые для меня особенно авторитетны» (18 \%); «Мои ученики сами решают, что они будут делать и чему научатся» $(14,4 \%)$. Также выявлен 1 \% педагогов, которые редко об этом задумываются.

При ответе на вопрос «Что из перечисленного ниже, на Ваш взгляд, наиболее точно отражает сущность понятия «образовательный результат?»» 55 \% педагогов определили его как «Опыт ребенка, полученный им в процессе решения проблемной задачи»; 50,5 \% - как «Шаг ребенка к самостоятельности», 42,3 \% - как «Полезные сведения, которые ребенок получил и запомнил для будущей жизни». Также 31,5 \% опрошенных педагогов отвечают, что образовательный результат - «Это то, чему ребенок научился сам с моей помощью»; 30,6 \% - «Это изменения, произошедшие с ребенком после того, как он столкнулся с чем-то новым для себя». Менее выражена точка зрения педагогов на образовательный результат как на то «Чему мне удалось научить ребенка» (20,7 \%); «Частичку моего взрослого опыта, который Я дарю ребенку» $(17,1 \%)$; 
«Усвоенный образец, при помощи которого ребенок сможет что-либо сделать правильно» $(16,2 \%)$.

На вопрос «Что вызывает у Вас наибольшие затруднения, когда решается вопрос о том, чему конкретно должны научиться Ваши ученики?» 26,1 \% опрошенных педагогов ссылаются на то, что «Не хватает времени об этом думать, приходится делать слишком много никому не нужной, формальной работы»; у 24,3 \% педагогов «Нет уверенности, что конкретного ребенка можно успешно обучить тому, что запланировано»; 23,4 \% респондентов отмечают отсутствие затруднений при решении данного вопроса. По 12,6 \% педагогов в качестве затруднений выделяют «Нехватку опыта индивидуального подхода к каждому ребенку», «Отсутствие необходимых методических средств», «Отсутствие необходимой нормативной базы, возможности выбирать, чему именно нужно научить конкретного ребенка».

Анализ ранжирования педагогами показателей высоких образовательных результатов (ответы на вопрос «Что из перечисленного, на Ваш взгляд, больше всего говорит о высоких образовательных результатах Ваших учащихся?») показал следующее: наиболее значимым показателем являются «Наблюдаемые педагогом «точки роста»»; затем следуют формальные показатели «Успешность учащихся в выполнении проверочных заданий и контрольных работ» и «Наличие дипломов победителя различных конкурсов, олимпиад и т.д.». На четвертое место педагоги ставят такой показатель как «Благодарность, которую высказывают Вам бывшие ученики при случайных встречах на улице», на пятое - «Положительные экспертные оценки и внешние отзывы об успехах и достижениях». В качестве наименее значимых показателей высоких образовательных результатов (6 и 7 ранги) педагоги 
выделяют «Успешное участие в специально организованных творческих испытаниях в самом образовательном учреждении» и «Благодарности родителей учащихся, в которых отмечается, что их дети стали более самостоятельными, творческими и успешными».

Таким образом, проведенное исследование позволяет утверждать, что современная практика дополнительного образования в значительной степени ориентирована на первый из выделенных типов образовательных результатов учащихся, то есть на подлежащие усвоению нормы, предъявляемые в готовом виде и не предполагающие их преобразование в процессе решения творческих задач. В этом смысле современное дополнительное образование детей по-прежнему испытывает сильное влияние традиционных взглядов и подходов, порожденных классической дидактикой. Взгляд на образовательный результат второго типа - как освоенный способ действия, необходимый для решения определенного круга стандартных и нестандартных задач, - представлен в современной практике дополнительного образования менее широко. Этот способ понимания образовательного результата формируется под влиянием идей компетентностного подхода и в настоящее время представлен в отдельных инновационных практиках дополнительного образования, реализуемых в новых форматах образовательной деятельности (в первую очередь, образовательных лагерей). Что же касается понимания индивидуального образовательного результата как обретаемой ребенком возможности самостоятельного продвижения по индивидуальной образовательной траектории (третий из выделенных подходов), то он представлен в существующих практиках дополнительного образования детей в наименьшей степени. 
В то же время данные проведенного опроса свидетельствуют, что значительная часть педагогов дополнительного образования (в первую очередь находящихся на ранних стадиях своего профессионального становления) интуитивно ориентирована на ребенка, его интересы, склонности и образовательные потребности при определении цели его образования. Это обстоятельство может рассматриваться как предпосылка становления новых практик дополнительного образования, базирующихся на принципе индивидуализации. Однако реализация этой предпосылки предполагает системные инновационные преобразования существующих моделей процесса дополнительного образования. Необходимо не только разработать эти новые модели, но и выявить педагогические условия становления деятельности по полаганию и формирующему оцениванию индивидуальных образовательных результатов учащихся, интегрированной в разнообразные социокультурные практики.

2.2. Проектирование индивидуальных образовательных результатов учащихся в процессе дополнительного образования

Проектирование индивидуальных образовательных результатов учащихся выступает важнейшим условием индивидуализации учебно-воспитательного процесса, который, как отмечается в современных исследованиях, «ориентирован прежде всего на процесс самообразования школьников и позволяет педагогам в своей работе учитывать прежде всего индивидуальные образовательные цели и приоритеты каждого ученика» [39]. Кроме того, проектирование индивидуальных образовательных резуль- 
татов открывает новые возможности обеспечить подлинно инклюзивный характер образования, поскольку предполагает достижение каждым ребенком собственного максимума реализации творческих успехов в проживаемой им социальной ситуации развития. Особенно благоприятными условиями реализации принципа индивидуализации обладает сфера дополнительного образования, где субъектность учащегося реализуется им, в первую очередь, в виде свободного выбора интересующих его видов творческой деятельности. В современных исследованиях отмечается такая специфическая особенность процесса дополнительного образования, как его ориентация на развитие потенциальных возможностей каждого ребенка, что изначально определяет его индивидуализированный характер (В.А. Березина, М.И. Болотова, А.В. Золотарева, А.Д. Насибуллина, А.И. Щетинская и др.). В то же время проектирование индивидуальных образовательных результатов не отрефлексировано в педагогическом сознании как особый вид совместной деятельности учащихся и педагогов, лежащей в основе выстраивания индивидуальной образовательной траектории ученика. В большей степени укоренены представления о том, что учащиеся (и их родители) могут становиться субъектами выбора образовательной программы, результаты освоения которой отражают лишь приемлемый для них уровень сложности учебного материала [69].

Проблема, лежащая в основе нашего исследования, состоит в научном обосновании методологических принципов и технологии проектирования индивидуальных образовательных результатов учащихся как шагов их осмысленного продвижения в зону ближайшего развития, сопровождаемого расширением спектра творческих возможностей познания и преобразования окружающего ми- 
ра. Такое понимание индивидуальных образовательных результатов в большей степени отвечает новым реалиям динамично изменяющейся действительности. В первую очередь, это стремительное развитие технологий, которые, по оценкам исследователей, «в ближайшее время охватят собой всю ойкумену - освоенную человечеством часть мира - и тем самым трансформируют все сферы бытия и системы жизнеобеспечения людей» [60, с. 23]. В этих условиях понимание образовательных результатов вне контекста расширения спектра индивидуальных творческих возможностей личности и ее устремленности в мало предсказуемое будущее не только не является продуктивным, но и чревато приближением гуманитарной катастрофы. Как, в частности, отмечает М.А. Лукацкий, «скорость, с которой стало преобразовываться пространство бытия человека, стала такой, что успеть за стремительными изменениями, происходящими во всех сферах жизни, удается меньшинству, а большинство уже составляет обширную команду аутсайдеров этого процесса» [60, с. 17].

Как уже было сказано, что индивидуальный образовательный результат, понимаемый в контексте совершения субъектом шага своего продвижения по индивидуальной образовательной траектории, по своей сути представляет собой самостоятельно найденный учащимся ответ на смыслообразующий «вопрос к Культуре». Поэтому индивидуальные образовательные результаты, получаемые учащимися в процессе дополнительного образования связаны, в первую очередь, с обретаемыми в ходе решения творческих задач смыслами как индивидуальными значениями понятий (А.Н. Леонтьев). (В этом нам видится существенное отличие сферы дополнительного образования от общеобразовательной школы, где учебно- 
воспитательный процесс чаще всего нацелен на усвоение учащимися общепринятых значений изучаемых понятий.) Кроме того, индивидуальные образовательные результаты ребенка включают в себя освоенные способы действий, при помощи которых он реализует свою собственную, субъектную позицию и презентует ее окружающим людям, добиваясь таким путем социального утверждения результатов своей деятельности.

Следуя этой логике, необходимо признать, что проектирование индивидуальных образовательных результатов, достигаемых в процессе дополнительного образования, должно осуществляться не в традиционной («школьной») логике разработки образовательных программ, где результаты обучения планируются автором безотносительно социальной ситуации развития конкретного ребенка, а, в лучшем случае, адаптируются к возрастным особенностям «усредненного» ученика. Сами же результаты обучения, хотя и понимаются как достижения самих учащихся, оцениваются по таким критериям, как «уровень усвоения учащимися программного материала», «положительная мотивация учения» и «ценности, преобладающие в детских коллективах» [86, с. 226-227]. Другими словами, образовательные результаты учащихся рассматриваются как достигнутый уровень усвоения учебного материала, предназначенного для всех, безотносительно собственных запросов конкретного ученика. Такая логика планирования образовательных результатов характерна для традиционных образовательных систем, в которых роль различных социальных институтов (в первую очередь, школы) первична по отношению к ребенку в процессе его социализации.

Принципиально иной подход присущ образовательным системам, проектируемым на основе принципа 
индивидуализации. Ребенок здесь выступает самодостаточным институтом, носителем образователь-ных потребностей, лежащих в основе выстраивания его индивидуальной образовательной траектории. Этот процесс осуществляется в условиях выбора и освоения разнообразных информационных и образовательных ресурсов, не «привязанных» к одному конкретному образовательному учреждению. Меняется и роль педагога, который становится для ученика своего рода «навигатором» в открытом информационно-образовательном пространстве [43].

В этой связи возникает необходимость, во-первых, обоснования методологических принципов, на основании которых проектирование индивидуальных образовательных результатов может осуществляться в процессе продуктивных субъект-субъектных взаимодействий педагогов и учащихся, во-вторых, создания технологии, которая может быть успешно реализована с учетом особенностей процесса дополнительного образования. Решая первую из этих задач, мы выделяем следующие принципы проектирования индивидуальных образовательных результатов как совместной деятельности педагогов и учащихся.

1. Принцип ориентации на зону ближайшего развития ребенка. Данный принцип широко распространен и служит главным основанием при проектировании образовательных систем, ориентированных на развитие ребенка (В.В. Давыдов, Д.Б. Эльконин, А.Н. Тубельский, Е.Е. Кравцова, Г.А. Цукерман и др.). Его суть состоит в том, что «учитель не учит тому, с чем ребенок хорошо справляется сам. Ребенок приходит в школу, чего-то не умея, с помощью учителя он обретает все большую самостоятельность и, наконец, может действовать без посторонней помощи, он не нуждается более в руководстве, указаниях, сотрудничестве» [96, с. 62]. Однако применительно к решению задачи 
проектирования индивидуальных образовательных результатов учащихся этот принцип обретает новые смысловые акценты. Во-первых, отметим, что проектируемые индивидуальные образовательные результаты могут «прорастать» исключительно из уже имеющегося у ребенка опыта, их прожитых ранее циклов развития. Как отмечает И.А. Корепанова, «появление нового в развитии всегда основывается на пройденных циклах развития. Для его возникновения должна быть подготовлена соответствующая почва» $[48$, с. 45$]$. В нашем случае это означает, что, проектируя новые индивидуальные образовательные результаты конкретного ребенка, педагогу дополнительного образования необходимо учитывать и опираться на его прежний опыт, на предшествующие достижения. Даже если ребенок выбирает совершенно новый для него вид деятельности, педагогу необходимо выявить имеющиеся у ученика предпосылки его успешного освоения и опираться на них, выстраивая совместно с ребенком его индивидуальный образовательный маршрут.

Во-вторых, проектирование индивидуальных образовательных результатов неотделимо от проектирования новых средств, при помощи которых эти результаты могут быть достигнуты. Эти средства, являясь новыми для учащихся, задают поле новых возможностей решения творческих задач, которые прежде могли быть решены только с помощью педагога.

И, в-третьих, проектирование индивидуальных образовательных результатов предполагает одновременное проектирование новых способов продуктивных коммуникаций учащихся и педагога. Эти коммуникации должны соответствовать достигаемому в процессе совместной творческой деятельности учащихся уровню их образова- 
тельной самостоятельности и задавать перспективы ее дальнейшего развития.

2. Принцип событийности. Согласно культурноисторической концепции Л.С. Выготского, событийность выступает необходимым условием взаимодействия взрослого и ребенка в процессе формирования высших психических функций. Нетрудно понять, что данному принципу должен быть подчинен и процесс проектирования индивидуальных образовательных результатов. Речь идет об особой «со-бытийной» общности, в которой пребывают педагог и ребенок, выходящий в пространство освоения новых творческих возможностей. Многие исследователи, в частности, Г.А. Цукерман, отмечают, что «понять неаддитивный характер взаимодействия в ЗБР чрезвычайно трудно, если рассматривать отношение "ребенок - взрослый" как отношение неумелого и незнающего с умелым и знающим» $[96$, с. 64]. Событийность достигается путем построения особых отношений, при которых ребенок действует самостоятельно, а взрослый (педагог) обеспечивает успешность этой самостоятельности, приходя на помощь именно в тот момент, когда ребенок приближается к границе уже освоенных ранее возможностей. Таким образом совместное действие взрослого и ребенка становится целостным, то есть, событийным. Как отмечает Б.Д. Эльконин, «но главное - совокупное действие. В нем меняется характер ориентации. Ориентация на действия другого есть одновременно ориентация своего действия» [108]. Именно событийный характер взаимодействия педагога и ребенка становится главным условием субъектной включенности ребенка в процесс проектирования своих индивидуальных образовательных результатов.

3. Принцип пробного действия. Основу данного принципа также составляет концепция Б.Д. Эльконина, согласно которой продвижение учащихся в зону своего ближайшего развития осуществляется как пробное действие, об- 
ладающее определенными внутренними закономерностями. Прежде всего отметим, что результат совершаемой пробы становится для субъекта инструментом совершения последующих проб [104]. С этой точки зрения индивидуальные образовательные результаты представляют собой не нечто, изначально запрограммированное в окончательном виде, а «цепочки» достигаемых в процессе совершения проб промежуточных результатов, выступающих для субъекта ориентирами его продвижения к поставленной цели. Другими словами, проектируемые индивидуальные образовательные результаты характеризуются возможностью несовпадения того, что было запланировано, и того, что достигнуто. Поэтому планирование индивидуализированного процесса дополнительного образования должно осуществляться как выбор направлений возможного «разворачивания» индивидуальной образовательной траектории учащихся, но не как указание на «конечный пункт» этого продвижения.

Далее мы переходим к рассмотрению вопроса об учащихся и педагогах дополнительного образования как о главных субъектах проектирования индивидуальных образовательных результатов.

2.3. Учащийся как субъект проектирования индивидуальных образовательных результатов в процессе дополнительного образования

Проблема становления учащегося как субъекта проектирования своих индивидуальных образовательных результатов обозначилась в поле психологических и педагогических исследований сравнительно недавно в связи с изменениями, происходящими в мире современного образования. Взгляд на учащегося в этом новом качестве от- 
ражает такие аспекты современной образовательной действительности, как возникшая у него возможность самостоятельно выбирать способы и форматы получения качественного образования, отвечающего целям личностного и профессионального самоопределения, в открытом информационном пространстве [35]; многообразие и вариативность социальных ситуаций развития детей, чья социализация происходит в разных социокультурных условиях [6]; становление образовательных экосистем путем интеграции сетевых образовательных сообществ [93]; развитие тьюторских антропопрактик, обеспечивающих индивидуализацию образовательного процесса [42].

Способность учащегося проектировать индивидуальные образовательные результаты, становящиеся для него не только средством познания и преобразования окружающего мира, но и важнейшим ресурсом обретения своей культурной и гражданской идентичности, связана с достижением качественно нового уровня субъектности, не представленного в массовой практике образования прошлых лет. Этот уровень характеризует учащегося как субъекта образовательного процесса в единстве его мотивов, ценностей, индивидуальных смыслов, компетентностей в различных видах деятельности и в общении с другими людьми, и, в целом, как личность, обладающую развитым самосознанием, Я-концепцией и самооценкой [74].

Разумеется, достижение такого уровня субъектности ученика представляет собой задачу, решаемую им совместно с педагогами и другими людьми (родителями, сверстниками и т.д.) на протяжении достаточно длительного периода реализации индивидуальной образовательной траектории, проходящей через различные события его жизни. Описанию данного уровня субъектности учащегося, характеризуемого его готовностью проектировать 
индивидуальные образовательные результаты посвящена настоящая статья. Характеристики данных уровней и этапов адаптированы к условиям сферы дополнительного образования, обладающей, как было показано ранее, специфическими условиями, особо благоприятствующими достижению учащимися индивидуальных образовательных результатов.

Прежде всего необходимо охарактеризовать разнообразие видов и уровней проявления субъектности учащегося, определяющие возможности его продвижения по индивидуальной образовательной траектории. Самый первый уровень связан с «первым рождением личности», которое А.Н. Леонтьев определял как формирование первых иерархически выстроенных отношений и мотивов [58]. Обладая этим уровнем субъектности, учащийся может самостоятельно выбирать те занятия, которые в наибольшей степени соответствуют его интересам и представлениям об их важности и значимости для самого себя, и в то же время отказываться от занятий, которые ему не интересны и не значимы. Следует отметить, что даже таким, казалось бы, общедоступным уровнем субъектности обладают далеко не все учащиеся, пришедшие в учреждение дополнительного образования, поскольку определенная часть из них посещает занятия либо по принуждению родителей, либо в целях общения и приятного времяпрепровождения со сверстниками [61]. Разумеется, на данном уровне учащийся еще не является субъектом проектирования индивидуальных образовательных результатов, его субъектный выбор чаще всего носит спонтанный характер, процесс целеполагания собственного продвижения по индивидуальной образовательной траектории, как таковой, еще не сформирован. Однако обретаемый на этом этапе развития субъектности уча- 
щегося социальный опыт становится основой его ориентации в проблематизированных «полях Культуры», где ему предстоит выбор приоритетов дальнейшего продвижения по индивидуальной образовательной траектории на ценностно-смысловом уровне. Согласно концепции Н.Ф. Головановой, структурными компонентами этого опыта становятся представление о базовых жизненных ценностях, полученная из разных источников информация, при помощи которой он объясняет для себя различные события и явления жизни, и определенные способы социального поведения, мотивированные стремлением действовать в смысловой рамке обретенных представлений [21, с. 188-189].

Позиция субъекта становящейся учебной деятельности представляет собой второй уровень субъектности учащегося. Возможные проявления такой субъектности весьма разнообразны и отражают различные аспекты выстраивания целостного образовательного процесса. Во многом это зависит от того, на каких принципах базируется организация учебно-воспитательного процесса, и какие компетенции «делегированы» учащемуся в ходе его продвижения в учебном материале. Так, в системах развивающего обучения (В.В, Давыдов - Д.Б. Эльконин) учащиеся поставлены в позицию субъектов выбора существенных характеристик индивидуального образовательного продвижения: периода подготовки к проверочным работам, сроков и способов предъявления достигаемых результатов и т.д.

Важным этапом развития субъекта учебной деятельности становится достижение им уровня контрольнооценочной самостоятельности [101]. Достигнув этого уровня субъектности, учащийся обретает возможность самостоятельно оценивать правильность выполненных 
заданий, обнаруживать и исправлять допущенные ошибки. Тем самым он повышает собственный уровень субъектности, освобождаясь от необходимости внешнего контроля.

Однако эти проявления еще не обеспечивают становление целостного субъекта образовательной деятельности. Шаг к этой целостности представляет собой развитие способности ученика совершать продуктивные учебные действия, которые, по утверждению Б.Д. Эльконина, лежат в основе подлинно субъектной учебной деятельности ребенка [106]. Характерно, что для освоения этого уровня субъектности ребенку необходимо создать особое деятельностное пространство, в котором его собственная творческая активность не подчинена жесткому контролю педагога (Б.Д. Эльконин именует это пространство «черновиком»).

Характеризуя в этом смысле подростка как субъекта деятельности, К.Н. Поливанова подчеркивает, что он строит свою собственную субъектность как субъективность авторства, то есть, он лишь постольку является субъектом, поскольку замысливает и осуществляет собственное действие, получает собственный продукт и тем самым проявляет собственный замысел [75].

Можно утверждать, что в существовавших до настоящего времени представлениях уровень совершения самостоятельного продуктивного действия представлен как наивысший уровень проявления субъектности учащегося в образовательном процессе, поскольку он включает важнейшие составляющие субъектной деятельности: целеполагание, планирование, собственно совершение действия, оценку результатов и рефлексию. Однако при этом остаются в силе ограничения субъектности, связанные с особенностями обучения в общеобразовательной школы. В 
условиях классно-урочной системы учащемуся недоступны возможности свободного выбора той предметности, на которой могут осуществляться его продуктивные пробные действия, поскольку жестко структурированная формальная образовательная среда школы сохраняет необходимость продвижения учащегося в заранее сконструированном учителем учебном материале как последовательности запланированных учебных предметов, разделов и тем. Как отмечают по этому поводу разработчики форсайт-прогноза «Образование-2030», «почему-то считается, что люди, родившиеся в один год, должны все вместе ходить на одни и те же уроки. Тебе восемь лет? Иди учи названия травок на лугу. Тебе четырнадцать? Тогда заучивай названия химических элементов. Никого не волнуют ни твои личные интересы, ни твой уровень развития в той или иной области» (цит. по: [90]).

Сфера дополнительного образования открывает учащимся возможность освоения качественно нового уровня субъектности, проявляющимся их готовностью конструировать индивидуальную образовательную траекторию, проходящую через различные виды творческих занятий и образовательные события, в ходе которых ими осваиваются не только новые способы учебных действий и их социального утверждения, но, как было показано выше, обретаются уникальные смыслы творчески преобразуемой культурной среды. Проектирование индивидуальных образовательных результатов становится при этом центральным механизмом продвижения по траектории, не заданной в готовом виде как индивидуальная образовательная программа, а выстраиваемой как свободный, творческий поиск сфер приложения собственных сил и самореализации. 
Готовность учащегося к такому поиску становится центральной, интегрированной характеристикой данного уровня его субъектности в образовательном процессе, а ее формирование выступает важной целью взаимодействия детей и педагогов дополнительного образования.

Можно охарактеризовать следующие компоненты готовности учащегося к проектированию индивидуальных образовательных результатов в процессе дополнительного образования.

Мотивационно-целевой компонент включает в себя совокупность смыслообразующих мотивов, определяющих направленность образовательных потребностей учащегося и уровень социальных притязаний, на котором эти потребности могут быть удовлетворены в процессе освоения различных социокультурных практик. Мы выделяет три таких уровня, задаваемых особенностями мотивов, лежащих в основе творческой деятельности учащихся. На первом уровне учащийся осуществляет свободную пробу, в ходе чего удовлетворяет свой интерес и определяет свое отношение к предмету деятельности (нравится - не нравится, интересно - не интересно, мое - не мое и т.д.). На втором уровне преобладают социальные мотивы, учащийся стремится путем освоения избранной социокультурной практики определенным образом строить свои отношения с окружающим социумом (получить признание, быть принятым в социальную группу, в целом, лучше адаптироваться к социокультурной ситуации проживаемого жизненного этапа). Третий уровень притязаний учащегося связан с доминированием мотивов творческой самореализации в избранном виде деятельности и обретением своей культурной идентичности активного преобразователя окружающего мира. 
Разумеется, уровень социальных притязаний оказывает существенное влияние на устойчивость мотивации и интереса учащегося к избранному предмету деятельности и задает перспективу дальнейшего продвижения по индивидуальной образовательной траектории к новым, отвечающим этим мотивам образовательным результатам.

Содержательный компонент этой готовности включает в себя освоенные учащимся способы целеполагания и планирования деятельности по освоению избранных социокультурных практик и способность находить и использовать разнообразные ресурсы и средства для достижения поставленных целей (включая ресурсы внешней информационной среды, теоретические знания, различные модели преобразуемых объектов, выразительные средства, а также коммуникации с партнерами по совместной деятельности). Важной характеристикой этого компонента готовности учащегося к проектированию своих индивидуальных образовательных результатов выступает степень их универсальности как возможности эффективного применения для решения широкого круга творческих задач. Так, например, осваивая сценическое искусство социокультурную практику, учащийся становится перед необходимостью использования разнообразных выразительных средств (речь, мимику, жесты, движение и т.д.). Для оценки степени универсальности этих средств для самого учащегося педагогу дополнительного образования важно учитывать, насколько учащийся готов использовать эти выразительные средства в других ситуациях, непосредственно не связанных с игрой на сцене (в дискуссиях, публичных выступлениях и других событиях, основанных на коммуникациях различных субъектов).

Третий, регулятивно-оценочный компонент готовности субъекта к проектированию индивидуальных обра- 
зовательных результатов содержит способность самостоятельно оценивать достигнутые результаты и корректировать на этом основании дальнейшее продвижение по индивидуальной образовательной траектории. Важной характеристикой этого компонента выступает способность ученика не только оценивать достигнутые результаты как таковые, но и самостоятельно определять их субъективное значение для дальнейшего продвижения по образовательной траектории. Для этого достигнутые результаты необходимо осмыслить как новые возможности, расширяющие круг творческих задач, которые может решать учащийся при помощи деятельностных средств, обретенных в процессе освоения социокультурных практик.

Таким образом, можно заключить, что учащийся, осваивающий роль субъекта проектирования индивидуальных образовательных результатов, представляется феноменом, еще не представленным в существующей практике дополнительного образования. Охарактеризованный уровень субъектности выступает сегодня объектом социально-педагогического проектирования, объединяющим усилия не только педагогов дополнительного образования, но и всего образовательного сообщества России.

2.4. Педагог дополнительного образования как субъект проектирования индивидуальных образовательных результатов ребенка

Индивидуализация образования, как базовый принцип проектирования образовательных систем в современных социокультурных условиях и как задача, остро стоящая сегодня перед педагогическим сообществом, в 
большей степени представляет собой «зону ближайшего развития» российского образования, нежели уже состоявшийся шаг в будущее. Внедрение новых педагогических технологий, ориентированных на развитие индивидуальности каждого ребенка, по мнению многих современных исследователей, сопряжено со значительными трудностями и рисками профессионализации педагогов. Переход к индивидуализированным моделям образования требует системных изменений профессионального педагогического сознания, формирования личностно ориентированной позиции педагога как необходимого условия его адаптации новым условиям глобальных изменений действительности. Как отмечает, в частности, Н.Н. Шевелева, «в сложившихся условиях учитель должен быть готов и уметь изменяться для того, чтобы сформировать у ученика необходимые компетенции для выбора своей траектории развития в современной социокультурной ситуации» [100, c. 122].

Далеко не в последнюю очередь это относится к деятельности педагогов дополнительного образования. В современных исследованиях подчеркивается, что «дополнительное образование детей можно характеризовать как эффективную структуру образования, которая развивает деятельностные и коммуникативные умения детей, способность делать выбор при решении познавательных, ценностно-ориентационных, преобразовательных, проектных задач, учит самоопределению, а также как зону перспективного развития каждого ребенка» [65]. Однако, несмотря на то что эта сфера образования издавна признается исследователями наиболее благоприятной для развития индивидуальности и творческих способностей каждого ребенка [5], речь скорее идет опять же о потенциальных возможностях учреждений дополнительного 
образования стать для него местом максимального раскрытия своего творческого потенциала. Для реализации этой возможности необходимы не отдельные мероприятия по совершенствованию образовательного процесса, а системные и непрерывные преобразования, позволяющие находить адекватные ответы на новые вызовы культуры и изменения, которые сегодня происходят в собственно Мире детства. В этой связи исследователями отмечается необходимость формирования новых компетенций педагогов дополнительного образования, связанных с осуществлением ими инновационной деятельности [20].

Главное условие эффективности проектирования индивидуальных образовательных результатов в системе дополнительного образования детей - это освоение педагогическим сообществом новых средств организации субъект-субъектного диалога с учащимися, миром культуры и современным обществом. В дополнительном образовании суть коммуникаций - это совместная деятельность педагога и ребенка, направленная на создание и разрешение ситуаций взаимодействия с ближайшим социальным окружением. Исходя из сказанного, реализация модели совместного проектирования индивидуального образовательного результата предполагает ориентацию педагогов дополнительного образования на обеспечение следующих условий:

- возможность свободного выбора учащимися содержания и последовательности освоения социокультурных практик;

- доступность внешних информационных и образовательных ресурсов продуктивной деятельности по освоению данных практик;

- включенность учащихся в процессы целеполагания, проектирования, планирования деятельности по освое- 
нию социокультурных практик и оценки полученных результатов с использованием соответствующих методических инструментов;

- разработанность отраженных форм предъявления результатов творческой деятельности внешним экспертам.

Суть ожидаемых изменений в системе дополнительного образования детей состоит в освоении педагогами новых средств организации продуктивного взаимодействия личности учащихся и социокультурной среды их развития. Результатом образования в системе ДОД становятся освоенные учащимися новые смыслы и первоначальный опыт субъект-субъектного диалога ребёнка с миром культуры и обществом. Жизнь обучающихся и их подготовка к жизни не должны более разделяться в целостном образовательном процессе.

Однако следует учесть, что педагогу дополнительного образования приходится постоянно сталкиваться, бороться и преодолевать довлеющие над его сознанием профессиональные стереотипы, которые накапливались веками и закреплялись в педагогическом опыте в виде норм поведения, общения, мышления и деятельности. Они-то и являются главными барьерами для проектирования индивидуальных образовательных результатов учащихся:

- во-первых, это установка педагога на формирование и оценку индивидуальных образовательных результатов учащихся в соответствие с достижением им определенных уровней в рамках общей эталонной модели личности (это понимание образовательных результатов характерно и для многих современных управленцев), с заранее заданными качествами, отражающими устоявшиеся представления (во многом уже устаревшие), при этом, всё 
чаще господствует унифицированный подход к воспитанию у педагога и требования такого же рамочного мышления от учащихся;

- во-вторых, это представления о простоте, известности и управляемости индивидуальными образовательными результатами учащихся, распространённость мнения, что при «правильной» организации внешних педагогических условий, с неизбежностью будет обеспечена предсказуемость и определенность индивидуальных образовательных результатов;

- в-третьих, убежденность в преимуществе долгосрочного планирования развития личности учащихся по типу ранней профилизации (часто начиная с дошкольного возраста), приводящего к заранее намеченной педагогами цели независимо от желаний и образовательных потребностей самого ребенка и изменчивости направленности социально-экономического развития общества (например, мобильности рынка труда и динамики востребованных профессий).

Помимо этого, педагоги дополнительного образования изучали теорию и практику обучения и воспитания ещё советского образца, практически игнорирующую принцип индивидуализации, отражающий сущность педагогики гуманистического направления. Кроме этого, общение взрослого с воспитанниками в системе дополнительного образования часто превращается в монологическое не только благодаря изначальным авторитарным установкам педагогов, но и потому, что сами дети, стремясь к наиболее простому для них пути познания мира, ищут образцы «правильного» поведения в образовательных ситуациях. Отсюда уверенность педагога дополнительного образования в занятой им ролевой позиции транслятора готовых образцов опыта (знаний). 
Важную роль в анализе позиции современных педагогов играет также отсутствие у них желания выкладываться на работе и больше тратить сил на общение с воспитанниками в силу низкой заинтересованности результатами своего труда (в том числе - материальной) или профессионального выгорания.

Без преодоления указанных стереотипов, распространенных в современном профессиональном сознании педагогов дополнительного образования, организация образовательного процесса, ориентированного на достижение учащимися индивидуальных результатов, представляется невозможной.

Для их преодоления необходимо обеспечить совместное, объединяющее усилия самих учащегося и педагогов, проектирование индивидуальных образовательных результатов в личностно ориентированном контексте, в котором образование становится средством построения собственного, уникального пути ребенка к истинному себе, его самореализации. Система ценностей педагога должна переориентироваться с «ценного для меня» на способы реализации системы ценностей самих учащихся. Для педагога становится более важным не то, что и как он говорит и делает, а то, как учащиеся действуют, что им хочется мыслить, как вести себя и действовать, какие результаты проектировать и как их добиваться. В этом контексте индивидуальные образовательные результаты становятся отражением «индивидуального максимума развития учащихся», а не «всеобщим обязательным минимумом грамотности».

В нашем исследовании, как уже отмечалось, предложен подход, согласно которому эффективным механизмом индивидуализации дополнительного образования выступает проектирование индивидуальных образовательных 
результатов как совместная деятельность, осуществляемая педагогом и ребенком в условиях творческого освоения разнообразных социокультурных практик. В отличие от традиционного подхода, образовательные результаты ребенка здесь не определяются требованиями образовательной программы, а пошагово проектируются в процессе совершения свободных проб на предметности, отвечающей содержанию осваиваемой социокультурной практики. Методологическим основанием этой деятельности выступает принцип событийности. В контексте идей культурно-исторической психологии Л.С. Выготского событийность является главным условием, определявшим возможности взаимодействующих субъектов (педагога и ребенка) проектировать индивидуальные образовательные результаты в зоне ближайшего развития ребенка как его новые, еще не освоенные способности. Как отмечалось в первой главе, такими результатами выступают открываемые в процессе творческой деятельности смыслы, лежащие в основе субъективного переживания преобразуемой проблемной ситуации; субъективно новые способы действий, открывающие возможности решения нового круга творческих задач; способы социального утверждения процесса и результатов осуществляемой деятельности на уровне, отвечающем притязаниям ребенка.

Понимание проектирования индивидуальных образовательных результатов как совместной, событийной деятельности взрослого и ребенка определяет новые задачи профессионального развития педагога дополнительного образования. В первую очередь, речь идет о становлении его готовности к осуществлению событийных, то есть особых, субъект-субъектных взаимодействий с детьми разного возраста, в ходе которых субъектность педагога не подчиняет себе субъектность ребенка, а 
напротив, обеспечивает максимальные возможности ее проявления в ситуации совместного решения творческой задачи. Об особенности таких взаимодействий, в частности, пишет Г.А. Цукерман: «В масштабе ведущей деятельности происходит становление принципиально новых для ребенка типов детско-взрослых взаимодействий... Для взрослого задача построить встречу с ребенком на территории игры, учебной деятельности, непосредственно эмоционального или интимно-личностного общения - это всегда новая задача... Он впервые ищет способ подстроить свое действие под действие именно этого ребенка таким образом, чтобы в месте встречи двух действий возникло нечто новое» [96, с. 65].

Рассматривая в этой связи готовность педагога дополнительного образования как его интегративное профессионально-личностное качество, мы выделяем следующие его компоненты.

Мотивационно-целевой компонент представляет собой стремление педагога не транслировать в сознание ребенка заранее подготовленные и оформленные в «дидактической» логике компоненты социального опыта, а выявить его собственные образовательные потребности и устремления, мотивы и дефициты деятельностных средств, препятствующие их полноценной реализации. Говоря словами В.П. Зинченко, этот компонент связан с готовностью педагога не «вписывать себя в ребенка», а «вычитывать из ребенка» [30], изучать социальную ситуацию его развития и именно из нее выводить цели совместной с ребенком творческой деятельности.

Когнитивный компонент включает в себя знание законов психического развития детей разного возраста и владение способами действий: навигация в пространстве свободного выбора социокультурных практик для их 
творческого освоения; психолого-педагогическая поддержка учащихся в процессе свободного выбора ими целей освоения избранных социокультурных практик; организация разноуровневых продуктивных проб учащихся в процессе освоения ими избранных социокультурных практик; сотрудничество с учащимися на предметности совместного решения творческих задач; оказание учащимся помощи в затруднительных ситуациях, связанных с повышенным уровнем сложности решаемых творческих задач; организация ситуаций личностной и групповой рефлексии новообразований социального опыта, полученного в процессе освоения избранных социокультурных практик.

Процессуальный компонент включает в себя готовность педагога осуществлять субъект-субъектные взаимодействия с учащимися на всех этапах освоения социокультурных практик, сопровождать совместную творческую деятельность учащихся, преодолевать и регулировать конфликтные ситуации.

Вполне очевидно, что формирование этой готовности не может быть сведено к оснащению педагогов дополнительного образования некоторой суммой методических приемов. Более эффективной стратегией выступает поэтапное прохождение педагогами всего комплекса проблем, связанных с проектированием индивидуальных образовательных результатов ребенка. Решая эту задачу, мы разработали интерактивную образовательную программу повышения квалификации педагогов дополнительного образования, включающую пять основных этапов их восхождения к решению проблем индивидуализации образовательного процесса. Ее апробация была осуществлена на базе центра дополнительного образования «Хоста» г. Сочи. 
Дадим краткую характеристику этих этапов.

На первом этапе педагоги осваивают технологию изучения социальной ситуации развития ребенка. Частными методами решения этой задачи выступают экспертиза портфолио ученика, оценка продуктов его творческой деятельности, проведение беседы, организация пилотных проб и т.д. Однако наиболее важно помочь педагогам освоить общий принцип решения этой задачи, базирующийся на различении зон актуального и ближайшего развития ребенка. С этой целью мы предлагали педагогам составить психолого-педагогический портрет кого-либо из своих учеников. После этого составленные портреты мы анализировали совместно с педагогами, акцентируя их внимание на том, что именно является для них главными, смыслообразующими характеристиками ребенка. В ходе обсуждения выделяется три возможных варианта. Вариант первый: ребенок характеризуется посредством перечисления уже достигнутых им успехов и обретенного социального опыта (чему ребенок уже научился в своей жизни и чего достиг?). Вариант второй: ребенок характеризуется через сумму эмпирических проявлений, к которым, как правило, относятся его интересы, склонности, черты характера, виды предпочитаемых занятий и т.д. (т.е., каким он предстает перед нами здесь и сейчас). Вариант третий: главной характеристикой ребенка выступают обретенные ребенком возможности дальнейшего развития пространств его творческих достижений и сотрудничества с другими людьми, а также ожидание педагога относительно перспектив личностного и профессионального самоопределения ученика (чему он может научиться и какие новые для него задачи сможет решать в дальнейшем). Педагогам необходимо прийти к мысли, что в про- 
цессе анализа социальной ситуации развития ребенка необходимо использовать все три названных варианта. Однако именно третий вариант выступает главным основанием для проектирования индивидуальных образовательных результатов ребенка в зоне его ближайшего развития.

Цель второго этапа - научить педагогов осмыслять и презентовать ребенку предметность его занятий в творческом объединении в логике культуры, т.е., выявляя и раскрывая возможности преобразования и «достраивания» того, что уже создано до них другими людьми. Другими словами, педагогам необходимо научиться предъявлять ученикам предметность их деятельности не в виде норм и эталонов этой деятельности, а через их проблематизацию, т.е. через обнаружение и раскрытие еще нерешенных окончательно «задач-на-смысл». Проблематизацию, вслед за В.Т. Кудрявцевым мы рассматриваем как главный и наиболее педагогически целесообразный способ введения ребенка в пространство культуры [52] и как единственно возможный путь восхождения ребенка к творчеству. С этой целью мы просим педагогов дополнительного образования описать предлагаемые детям виды деятельности в их творческих объединениях именно как спектр возможностей их дальнейшего творческого преобразования. Эти описания должны содержать внутри себя своего рода «приглашение к творчеству» для ребенка, у которого необходимо сформировать понимание того, что конечные результаты его творческой деятельности в наибольшей степени зависят от его желания творить, творческих способностей, воображения и, в первую очередь, собственной активности. 
На третьем этапе педагоги учатся ставить учащегося в позицию субъекта целеполагания своих индивидуальных образовательных результатов. Одним из главных условий здесь выступает способность педагога открыть для ребенка весь спектр его потенциальных возможностей (чему он может научиться, участвуя в работе творческого объединения, и какое значение могут иметь эти результаты для удовлетворения его образовательных и социальных потребностей). Крайне важно сформировать в сознании ребенка два плана ответа на этот вопрос: внутренний («какие открытия я смогу сделать для себя?») и внешний («что хорошего я смогу сделать для других людей?»). Для этого педагогам дается задание еще раз составить описание деятельности, которой обучается ребенок в творческом объединении, но уже «изнутри» как «секреты мастерства». Тем самым можно очертить общий контур возможных перспектив и индивидуальных образовательных траекторий учащихся, реализуемых ими в процессе освоения избираемых социокультурных практик.

Четвертый этап посвящен обучению педагогов технологии организации разноуровневых социальных проб. Главное средство, которым должен овладеть педагог дополнительного образования, это постановка перед учащимися творческих задач, решая которые они не будут просто воспроизводить показанные им действия, а совершат попытки преобразовать существующую ситуацию, открывая в ней для себя ранее неизвестные возможности. Педагогам предлагается сформулировать творческие (проектные) задачи, ориентируясь на следующие правила: 1) поставленная задача не должна иметь уже известного ученику решения, оно должно быть «придумано» 
непосредственно в предложенной ситуации (для этого целесообразно оформлять ее в виде кейса);

2) для решения задачи необходимо искать дополнительную информацию в открытых источниках, а также опираться на имеющиеся у учащихся знания (но не использовать их как «готовое» решение);

3) эффективность социальной пробы повышается, если решение задачи осуществляются совместно несколькими учащимися;

4) педагог не только может, но и должен взаимодействовать с учащимися в процессе совершения пробы: обсуждать предлагаемые решения, задавать наводящие вопросы, делать подсказки (но только такие, которые не содержат в себе готовых «рецептов» и решений);

5) найденный способ решения задачи должен быть оформлен в виде продукта, который далее должен стать предметом общего обсуждения, оценки и самооценки авторами.

На пятом этапе педагогам необходимо научиться способам создания ситуации рефлексии учениками собственных достижений и дефицитов образовательного опыта, выявленных в ходе совершения социальных проб.

Для этого им предлагается разработать методические инструменты: схемы самоанализа учащихся, творческие задания для написания эссе, вопросы к интервью и т.д. Кроме того, на основе полученных данных необходимо разработать и освоить процедуры планирования совместно с учащимися их дальнейших шагов, направленных на освоение новых социокультурных практик, обладающих более высоким креативным потенциалом, и отвечающих более высоким уровнем социальных притязаний учащихся. 
После прохождения этих этапов обучения каждый педагог дополнительного образования при сопровождении наставника проходит полный цикл проектирования индивидуальных образовательных результатов с учащимися своего творческого объединения, анализирует полученные результаты и намечает цели дальнейшего профессионального саморазвития.

В заключение необходимо отметить, что предлагаемый подход выступает альтернативой традиционным методам планирования процесса дополнительного образования и даже в некоторой степени вступает в противоречие с действующей нормативной и методической базой. В преодолении этого разрыва нам видятся актуальные перспективы инновационного развития системы дополнительного образования детей в ближайшей временной и социокультурной перспективе.

\section{Выводы по второй главе}

В современной педагогической действительности укоренены различные способы полагания и оценки образовательных результатов учащихся. Однако большинство из них не обеспечивает эффективную реализацию принципа индивидуализации образования. Проектирование индивидуальных образовательных результатов как особый вид совместной деятельности учащихся и педагогов дополнительного образования обладает рядом особенностей, определяющих качественно новый уровень их субъектности в образовательном процессе.

В этом контексте возникает задача формирования готовности учащихся и педагогов к освоению этого уровня и его реализации в процессе проектирования индиви- 
дуальных образовательных результатов не по общепринятым нормам, а сообразно социальной ситуации развития ребенка.

Для решения этой задачи могут использоваться интерактивные методы их совместного обучения в процессе освоения модельных социокультурных практик. При этом закономерно возникает необходимость преобразования базовых оснований планирования образовательного процесса в учреждении дополнительного образования, в частности, именно эти социокультурные практики должны становиться его проектными единицами. Это обстоятельство определяет высокий уровень востребованности новых педагогических технологий целеполагания, сопровождения и оценки результативности совместной творческой деятельности учащихся и педагогов. 


\section{3. Методические и технологические аспекты проектирования индивидуальных образовательных результатов учащихся в системе дополнительного образования}

3.1. Педагогические условия становления учащегося как субъекта полагания индивидуальных образовательных результатов

Проектирование учащимся собственных образовательных результатов, как было сказано выше, рассматривается нами как эффективный механизм построения его индивидуальной образовательной траектории. Однако запуск этого механизма требует создания особых педагогических условий, не представленных сегодня в различных моделях индивидуализированного образовательного процесса. Обоснованию этих условий посвящен этот параграф.

Поставленную задачу мы решали методами анализа научной литературы и моделирования индивидуализированного образовательного процесса, где роль проектной единицы индивидуальной образовательной траектории ребенка отведена социокультурной практике. Предметом проведенного анализа стали выделяемые авторами проявления субъектности учащихся в целостном образовательном процессе. Моделируя процесс продвижения учащегося по индивидуальной образовательной траектории, мы, вдобавок к ранее обоснованному нами пониманию социокультурной практики как «педагогически целесообразно организуемой предметности индивидуально-групповой деятельности учащихся, в процессе освоения которой ими при помощи обретаемых культурных, проектно-преобразовательных средств модели- 
руются проблемно насыщенные сферы общественной жизни» [32, с. 44] мы учли и другие современные аспекты изучения данного феномена. Так, в работе В.В. Николиной отмечается, что социокультурная практика может пониматься как «совокупность развивающих образовательных сред, институтов, процессов, обеспечивающих различные формы организации социокультурной деятельности учащихся и выступающих средством приобщения обучающихся к культуре в широком смысле слова в процессе развития» [68, с. 272].

Проведенное исследование позволило получить следующие результаты. Анализ научной литературы показывает, что большинство современных исследований по проблеме субъектности учащихся базируются на представлениях о сущности учебной деятельности, ориентированной на самоизменение субъекта, и ее структурных компонентах. Освоение учащимся этих компонентов достаточно часто рассматривается авторами именно как центральное проявление ученика, выступающего в роли субъекта учебной, либо учебно-исследовательской деятельности. Так, например, в работе А.М. Антоновой говорится: «Формирование учащегося как субъекта учебноисследовательской деятельности предполагает обучение его умению планировать, организовывать свою деятельность, определять умения, необходимые для успешного исследования, и четкую организацию упражнений по их формированию. Существенным показателем учащегося, как субъекта учебно-исследовательской деятельности, является его умение выполнять все ее формы и виды» [4, c. 139-140].

В этом ключе вопрос о субъектности учащегося часто рассматривается с точки зрения занимаемой им внутренней позиции в процессе осуществления им этой деятель- 
ности. Так, например, в работе Г.В. Самусевой отмечается: «Позиция субъекта учебной деятельности учащихся - это конструкт личностного опыта, проявляющийся в способности ребенка к инициированию учебной активности, адекватной рефлексии процесса и результата ее выполнения, своих учебных достижений. В этой связи автор выделяет такие диагностируемые показатели субъектности учащихся, как «ответственное отношение к учебной деятельности, осознание ее личностной значимости (смысла), владение способами ее видения, опыт волевых усилий при достижении учебных целей, проявление самостоятельности, инициативы и критического отношения к своим достижениям» $[85$, с. 14$]$.

Одним из важных источников современных представлений о субъектности учащихся и ее проявлениях в различных педагогических ситуациях выступает концепция субъект-субъектных взаимодействий педагогов и учащихся, которая, как отмечает в своем исследовании Е.В. Коротаева, начиная с 80-х годов прошлого столетия приходит на смену прежней концепции «педагогического воздействия» [50]. В этой связи проявления ученика как субъекта образовательного процесса чаще всего рассматриваются авторами как его «ответ» на проявление субъектности учителя. По этому поводу, в частности, Л.М. Бронникова отмечает: «Но “субъект-учитель” имеет своей целью в процессе обучения математике создание оптимальных условий для формирования компетенции самообразования, диагностирование успехов учащегося, а “субъект-ученик” - с помощью учителя сформировать компетенцию самообразования, обусловленную социально-практической и личностной значимостью» [16, с. 151].

Еще один взгляд на ученика как субъекта образовательного процесса связан с представлениями о развитии 
творческой одаренности. Субъектность здесь понимается как свойство одаренного ученика, в то время как «обычные» учащиеся таковой субъектностью располагают в значительно меньшей степени. Так, например, И.Ю. Денисова полагает, что школьник может стать субъектом учебной деятельности только при условии, что он уже с первого класса научится придумывать, находить оригинальные решения, наблюдать и анализировать явления, проводить сравнения, обобщать факты, делать выводы, критически оценивать результаты деятельности и т.д. [26]. Едва ли можно в полной мере разделить эти взгляды, поскольку здесь имеет место не вполне правомерное отождествление субъектности и одаренности. Однако можно отметить такой аспект понимания субъекта учебной деятельности, как ее продуктивность, обеспеченная владением определенным арсеналом способов действий, не сводимых к формальному усвоению учебного материала.

И тем не менее приходится констатировать, что субъектность ученика в рамках этих представлений вторична по отношению к субъектности учителя, ее назначение состоит лишь в том, чтобы ученик «присвоил» учебную деятельность как личностно значимый, но все же заданный извне образец. В контексте представлений об учащемся как «авторе» проекта своей индивидуальной образовательной траектории такой уровень субъектности не отвечает уровню сложности решаемой экзистенциальной задачи и требуемого уровня самостоятельности и ответственности; речь, скорее, идет о позиции «квазисубъекта».

Следует отметить, что в современных исследованиях довольно часто предпринимаются попытки расширить контекст проблематики субъекта учебной деятельности путем введения в него таких понятий, как самоопределе- 
ние [97], гражданственность [66], а также посредством описания специфических ролевых позиций учащихся, не представленных в традиционных моделях образовательного процесса (к примеру, позиция ученика как субъекта инновационных процессов [9], как субъекта психологической экспертизы образовательной среды [57] и т.д.). Однако чаще всего в этих случаях субъектность характеризуется через набор качеств учащихся, но их субъектное включение в деятельность непосредственно не отражено. В других случаях такое расширение контекста базируется на вполне укорененных характеристиках субъекта учебной деятельности, но никакого качественного приращения к ним не прослеживается. Так, например, в работе Т.М. Чурековой, посвященной вопросам самоопределения и самореализации учащихся говорится: «Учащийся при таком взаимодействии, осуществляемом в рамках субъектсубъектного обучения, является, прежде всего, субъектом учения. Данная позиция предполагает, что учащийся усваивает (или даже «присваивает») содержание учебного материала, соотнося его с содержанием собственного опыта, накопленного как в процессе предшествующего обучения, так и в жизненной практике; сам регулирует свою познавательную деятельность на основе рефлексии не только результатов, но и процесса этой деятельности» [97, с. 93]. Нетрудно заметить, что «приращение» субъектности, выводящее ученика на уровень личностного самоопределения состоит здесь исключительно в том, чтобы осмыслить и отрефлексировать осуществляемую учебную деятельность как личностно значимую, сама же деятельность при этом по прежнему остается внешне заданной, не порождаемой самим субъектом как акт его творчества. В этом случае «присвоение» деятельности субъектом касается исключительно ее операционально-технической сто- 
роны (способы действий), в то время как порождение новых смыслов, связанных с развитием этой деятельности, практически не происходит.

Таким образом, можно утверждать, что существует труднопреодолимый разрыв между современными представлениями об ученике как о субъекте образовательного процесса и необходимостью достижения качественно нового уровня этой субъектности, реализуемой в полагании и оценке индивидуальных образовательных результатов. Этот качественно новый уровень субъектности требует выхода за рамки собственно учебной деятельности, поскольку самостоятельное осуществление индивидуальной образовательной траектории как «авторского проекта» предполагает не только разнообразие видов деятельности, осуществляемой субъектом образования (исследовательской, проектной, художественно-творческой и т.д.). В процессе создания такого проекта субъект представляет собой не просто совокупность функций, он проявляет себя целостно, обладая при этом специфическими свойствами, описанными в работах К.А. Абульхановой-Славской, А.Г. Асмолова, В.А. Петровского, Н.С. Пряжникова и других исследователей. К таким свойствам, в первую очередь, относятся:

- активность как исходная «потребность в деятельности», лежащая в основе ее разнообразных внутренних и внешних мотивов;

- неадаптивность как внутренняя устремленность сделать деятельность более интересной, чем того требует ее рациональные и прагматические основания;

- надситуативность как готовность не только ставить ближние и дальние цели деятельности, подчиненные конкретной ситуации, но и пересмотреть их, если эта ситуация перестает быть личностно значимой; 
- спонтанность как готовность отказываться от рациональных и ожидаемых схем, действовать интуитивно, рефлексируя при этом свою спонтанность и принимая ответственность за ее последствия.

Следует также учитывать, что деятельность субъекта по природе своей совместна и адресована другим людям, во взаимодействии с которыми происходит ее «социальное утверждение» (Б.Д. Эльконин).

С учетом сказанного нами построена модель индивидуализированного образовательного процесса, в котором субъектом осуществляется полагание индивидуальных образовательных результатов. При этом деятельность субъекта отвечает выделенным выше характеристикам. Эта модель базируется на закономерностях самостоятельного продвижения ученика по индивидуальной образовательной траектории, осуществляемой в логике Культуры, то есть как открытия субъектом «мира впервые» [12]. Этот процесс выстраивается как последовательность свободно выбираемых учащимися социокультурных практик, каждая из которых для них - это своего рода «terra incognita», где ребенку предстоит открыть для себя особые смыслы, не сводящиеся к усвоению общепринятых значений.

Исходя из этого, выделяются следующие функциональные компоненты данной модели.

1. Проблематизация культурных содержаний новой социокультурной практики (ценностно-смысловой компонент). Под «проблематизацией» мы, вслед за В.Т. Кудрявцевым, понимаем открытие в этих уже объективно известных содержаниях скрытых и еще не реализованных возможностей их творческого преобразования. Следует отметить, что именно проблематизация в современных исследованиях рассматривается как способ обращения к 
Культуре, имманентный самой Культуре. Так, В.Т. Кудрявцев отмечает: «Тот, кто созидает определенный фрагмент культуры, одновременно проблематизирует его для того, кто его осваивает (часто не явно, а подспудно)» [52, с. 116]. А для этого учащемуся необходимо построить в своем сознании первоначальную смысловую картину того, что ему открывается на этой «новой территории». Именно схватывание общего смысла создает у ребенка не просто общее представление о новой для него действительности (как это происходит в случае формального ознакомления), а позволяет ему увидеть эту действительность как спектр еще не реализованных возможностей ее творческого преобразования. Отметим, что этот спектр осмысляется каждым ребенком индивидуально, а поэтому формируется внутренний план становящейся деятельности: вопрос «что это?» перерастает в смысловые вопросы «зачем это, и кто я сам в этой новой для меня действительности?». В более формальном выражении эти вопросы сводятся к пониманию того, какое значение предъявляемые содержания культуры могут иметь для участников совместной творческой деятельности.

2. Выстраивание и реализация собственного проекта преобразования осмысленных культурных содержаний (содержательный компонент). Проект рассматривается здесь как сообразный Культуре «индивидуальный ответ» ученика на выявленные им «вызовы» социокультурной практики. Индивидуальный проект - это способ реализации возможностей творческого «достраивания» и преобразования культурных содержаний осваиваемой практики и одновременно - способ ее освоения субъектом. Особо отметим, что в данном случае предметностью освоения учащимися социокультурных практик выступают открытые ими самими возможности ее творческого преобразо- 
вания, а не нормативные способы действий с ее содержаниями, как в традиционной дидактике. Отметим также и то, что такой способ освоения культуры характерен для подлинного творчества, в первую очередь для искусства. Однако именно такой способ соответствует специфически детским видам деятельности, посредством которых ребенок строит свои субъектные отношения с окружающим миром. В первую очередь, это игра. Поэтому необходимо, чтобы все этапы становления и реализации индивидуального проекта (постановка проектной задачи, определение ресурсов, концептуализация, планирование, реализация, получение результата) были для учащихся пронизаны «духом игры». Как отмечает Б.Д. Эльконин, именно «логика игры» делает деятельность учащихся продуктивной и придает ей характер свободной пробы [105].

3. Выстраивание спектра продуктивных коммуникаций с партнерами по совместной деятельности (коммуникативный компонент). Данный компонент помимо прямого назначения, состоящего в вовлечении в проект партнеров и формирование таким путем у учащихся навыков сотрудничества, признан реализовать еще одну крайне важную функцию. Функция эта состоит в выделении в структуре социокультурной практики двух взаимосвязанных, но не сводимых друг к другу линий ее освоения. В этом смысле социокультурная практика представляет собой неразрывное единство этих двух линий, одна из которых направлена на освоение культурной проблематики, а вторая на развитие социальных отношений. В первом случае выстраиваемые коммуникации непосредственно интегрированы в деятельность по решению проектной задачи. Они «отвечают» за становление событийной общности участников проекта и придают освоению социокультурной практики характер образовательного события. Таким 
путем формируется событийная общность как коллективный субъект преобразования культуры. Во втором случае речь идет о становлении особого рода отношений между участниками проекта, которые Г.П. Щедровицкий, применительно к вопросам детской игры характеризовал как «отношения по поводу» осуществляемой деятельности [102]. Именно в этих отношениях происходит «социальное утверждение» деятельности, что, по мнению Б.Д. Эльконина, и придает ей пробно-продуктивный характер [104].

4. Оценка результатов освоения социокультурной практики и выявление на этой основе дефицитов образовательного опыта субъекта (рефлексивно-оценочный компонент). Назначение данного компонента состоит в том, чтобы вывести участников освоения социокультурной практики в рефлексивную позицию, в которой предметом их оценки становятся не только достигнутые результаты, но и изменения, произошедшие в них самих. Такая рефлексия позволяет учащимся отразить в своем сознании ситуацию их продвижения по индивидуальной образовательной траектории, которая характеризуется: а) уже освоенными преобразовательными средствами, обеспечивающими определенный уровень самостоятельности в этом продвижении; б) выявленными дефицитами собственного образовательного опыта как ориентирами полагания индивидуальных образовательных результатов на последующих ее этапах; в) новыми возможностями дальнейшего продвижения на основе построенных смыслов и обретенных деятельностных средств. В целом, процесс освоения социокультурной практики схематично может быть обозначен как «проблемное погружение - целеполагание - проект как совместное пробное действие рефлексия». 
Основные компоненты построенной таким образом модели позволяют нам сформулировать следующие педагогические условия, обеспечивающие эффективность их реализации. Условие первое мы формулируем как требование обеспечения каждому учащемуся возможности свободного выбора им не только самих осваиваемых социокультурных практик в соответствии со своими склонностями и интересами, но и целей их творческого преобразования.

Второе условие состоит в обеспечении разнообразия социально-ролевых позиций, которые могут занимать участники творческих проектов, позволяющие им выстраивать разнообразные продуктивные коммуникации.

Условие третье состоит в сочетании реалистичного и воображаемого планов совместной творческой деятельности субъектов освоения социокультурной практики, обеспечивающее игровую основу осуществляемой деятельности и придающей ей характер свободной социальной пробы.

Четвертое условие формулируется нами как включение в структуру совместной деятельности субъектов освоения социокультурной практики ситуаций индивидуальной и групповой рефлексии, обеспечивающих их непосредственное включение в полагание и оценку индивидуальных образовательных результатов.

Дальнейшее обоснование способов создания этих условий в образовательном процессе мы связываем, в первую очередь, со специфическими возможностями сферы дополнительного образования детей, где данная модель может быть реализована на базе разнообразных творческих объединений. 
3.2. Организация социальных проб учащихся учреждения дополнительного образования детей

В этом параграфе мы рассматриваем вопрос о конкретных педагогических средствах формирования учащегося как субъекта проектирования индивидуальных образовательных результатов. В концепции нашего исследования именно пробе и ее педагогической организации отводится роль главного механизма освоения ребенком культурных способов целеполагания своего продвижения по индивидуальной образовательной траектории и оценки достигаемых при этом результатов. В этой связи задача состоит в разработке и обосновании свободной социальной пробы, результатом которой становится самоопределение ученика в выборе целей своего дальнейшего образовательного продвижения и их оформление в собственном сознании как образа индивидуального образовательного результата, открывающего перспективы освоения «зоны ближайшего развития». Решая эту задачу, мы проанализировали научную литературу вопроса и на основе полученных результатов построили модель педагогически организованной свободной социальной пробы, которая может быть эффективно реализована в сфере дополнительного образования, которой в современном общественном и профессионально-педагогическом сознании наиболее часто отводится роль «зоны наибольшего благоприятствования» развитию творческих способностей ребенка.

Проведенный анализ позволил установить, что совершение учащимися общеобразовательных учреждений проб в различных сферах деятельности используется чаще всего как средство их профориентации. Профессиональные пробы студентов учреждений высшего и средне- 
го профессионального образования выступают распространенным в массовой практике средством их профессионализации. При этом чаще всего проба рассматривается как возможность непосредственного погружения в предстоящую деятельность в целях установления возможностей и целесообразности ее дальнейшего освоения. Так, например, по утверждению Н.Г. Иониной, «в процессе выполнения профессиональной пробы учащийся получает опыт той профессиональной деятельности, которую он собирается выбрать (или уже выбрал), и пытается определить, соответствует ли характер данной деятельности его способностям и умениям» [36].

Применительно к вопросам непосредственной подготовки студента к его будущей профессиональной деятельности профессиональная проба определяется, в частности, Л.С. Деминой как «специально организованное испытание, осуществляемое в специально организованной имитационной ситуации, в которой моделируются «элементы конкретного вида профессиональной деятельности, максимально приближенные к профессиональной реальности» [25, с. 136-137]. При этом утверждается, что «психологически профессиональные пробы - ресурс индивидуального поиска, профессионального самоопределения и развития» [25, с. 137].

Понятие социальной пробы используется в тех случаях, когда профессиональное самоопределение еще не является ближайшей перспективной образования. Так, применительно к проблемам становления гражданской идентичности младших школьников, Л.В. Калинина и А.В. Аверченко видят сущность социальной пробы в том, что «ученик выполняет социально-преобразующие действия на основе выбора способа поведения в новой ситуации». Результат же социальной пробы видится авторам в том, 
что «в процессе такой деятельности школьник знакомится с окружающей социальной средой, получает новую информацию об объектах и явлениях этой среды в ходе взаимодействия с ними, опыт самостоятельности и ответственности» $[37$, с. 334].

Характерно, что в обоих примерах (студенты и младшие школьники) наблюдается некоторая степень рассогласованности содержания совершаемой пробы и ее результатов. Так, в случае профессиональной пробы студентов, ее содержание, как отмечает автор, обязательно включает в себя «отработку необходимых приемов, методов, методик, т. е. конкретных способов реализации осваиваемых профессиональных действий в условиях специально организованной учебно-лабораторной среды» [25, с. 137]. Очевидно, что речь идет об уже существующих методах и методиках, соответствующих моделируемой ситуации профессиональной деятельности. Профессиональная проба здесь сводится к попытке использования этих «всеобщих» способов действий в индивидуальном опыте студента. Логика профессиональной пробы в данном случае - это логика учебного тренажера, на котором отрабатывается навык стандартизированного действия. В этой связи не вполне ясно, каким образом освоенный способ действия становится «ресурсом индивидуального поиска» (если, конечно, именно обретение индивидуального ресурса считать индивидуальных образовательным результатом совершенной пробы), и на что именно этот поиск должен быть направлен в дальнейшем.

В другом случае (формирование гражданской идентичности младших школьников) речь идет о социальнопреобразующем действии, реализуемой учащимся в новой ситуации, что позволяет интерпретировать социальную пробу как самостоятельное решение творческой задачи. 
Однако именно такое понимание социальной пробы в цитируемой работе не получило дальнейшего развития, а в приведенных авторами примерах сами ситуации и средства их решения представляются достаточно стандартными. Однако само важно здесь то, что сами по себе результаты социальной пробы сведены авторами к ознакомлению с окружающей средой и получению новой информации, на фоне чего идеи развития самостоятельности и ответственности носят в некоторой степени декларативный характер. Такое понимание результата прямо свидетельствует о репродуктивном характере совершаемой пробы и пассивной позиции ученика как ее субъекта.

Можно заключить, что в приведенных примерах проба ученика неразрывно связана с освоением образца, будь то способ действия, алгоритм, правило, или просто некоторый объем учебной информации. В современных исследованиях, связанных с идеями компетентностного подхода, такой взгляд на социальную пробу связан с понятием репродуктивной деятельности, которая «представляет собой деятельность по уже существующему, сколь угодно сложному, образцу; соответственно репродуктивные компетенции связаны с освоением такого образца и готовностью его применять в определенных условиях» [77, с. 53]. Репродуктивный характер социальной пробы задается в первую очередь путем имитирования ситуаций, для разрешения которых необходимы и достаточны такие усвоенные образцы. В отличие от этого социальная проба, предполагающая создание учащимся своего собственного образца (принятия оригинального и ответственного решения) предполагает моделирование принципиально иных ситуаций, в которых отсутствуют заведомо «правильные» т.е. нормативные решения. Такие ситуации, по утверждению авторов цитируемого источника, чаще всего 
встречаются в искусстве, в управлении, в выстраивании человеческих отношений, они характеризуются как ситуации экзистенциального выбора и самоопределения.

Вопрос о продуктивном либо репродуктивном характере социальной пробы - это, в первую очередь, вопрос о творчестве как базовой характеристики деятельности ученика. Противоречие между этими взглядами восходит к глубинному противоречию между традиционно укорененным в педагогике пониманием усвоения деятельности между присвоением культуры и «творчеством». Как отмечает по этому поводу В.Т. Кудрявцев, «присвоение культуры трактуется как пассивная (или даже активная, действенная) воспроизведение устоявшихся норм, образцов и эталонов человеческой деятельности, а творчество - как радикальный выход за рамки присвоенной культуры» [52, с.116]. Пока данное противоречие остается непреодоленным, организация социальных проб учащихся не имеет интенции к их выходу в зону ближайшего развития ученика. Для нашего исследования это означает, что социальная проба позволяет ученику действенно и эффективно осваивать пределы зоны своего актуального развития, но не может служить механизмом выхода за эти пределы. Соответственно это закрывает для ученика возможность осмысленного полагания индивидуальных образовательных результатов именно как целей выхода в зону ближайшего развития.

Дальнейшее обсуждение проблемы проектирования социальной пробы, творческой по своей природе, приводит нас к теории пробного продуктивного действия Д.Б. Эльконина. Прежде всего отметим, что в концепции автора «продуктивное действие есть не просто действие, а событие действия» [106]. Это положение основано на двойственности действия, содержащего в себе одновременно 
две порождаемые в нем ситуации: собственно предметную (что именно преобразуется, на какой предметности осуществляется действие) и социальную (что изменяется при этом в самом субъекте и окружающих людях). Эти две ситуации не только взаимосвязаны, но и едины, поскольку продуцирование действия невозможно без его социального утверждения, то есть, говоря словами самого Б.Д. Эльконина, «преодоления социальной пустоты вокруг выполнения действия» [106].

В свою очередь, событийность пробного действия «обеспечивает» внутреннюю взаимосвязанность способа действия как такового и порождаемого в этом действии смысла. (Отметим, что в приведенных выше примерах социальные и профессиональные пробы были жестко привязаны к осваиваемому способу, однако никак не касались порождаемых при этом смыслов, образующих событийную общность его участников.)

Еще одним крайне важным аспектом пробного действия выступает его соотнесенность с понятием социокультурной практики, которая в концепции Б.Д. Эльконина представляет собой форму внутренней связи способа и смысла как двух сторон пробного действия. Обратим внимание на то, что социокультурная практика, определяемая как «совокупность развивающих образовательных сред, институтов, процессов, обеспечивающих различные формы организации социокультурной деятельности учащихся и выступающих средством приобщения обучающихся к культуре в широком смысле слова в процессе развития» $[68$, с. 272], может пониматься двояко: либо как вновь предъявляемая ученику действительность (в обыденной практике - новая учебная тема), не имеющая отношения к его прежнему субъектному опыту, либо как органичное развитие этого прежнего опыта. Первый подход 
весьма распространен, он без особого труда «прочитывается» в приведенных выше примерах профессиональных и социальных проб. Второй подход, связанный с принятием событийной природы пробного действия, предполагает взгляд на это действие как на «единицу той социокультурной практики, которая осваивается в детстве» [104]. Другими словами, социокультурная практика оформляется в сознании как результат творческой активности самого субъекта (ребенка), который осваивает окружающую действительность специфическими детскими средствами. Развитие этой практики обусловлено развитием преобразовательных и познавательных средств, осваиваемых субъектом в каждом проживаемом возрасте.

С этих позиций сущность, назначение и результаты социальной пробы могут пониматься по-разному. Если социокультурная практика мыслится как нечто, задаваемое извне, как новый опыт, не «привязанный» к субъектному опыту ребенка, социальная проба представляет собой некое подобие «шлюза». Его назначение состоит в «сшивании» разрыва между наличным опытом ученика и новым опытом, подлежащим освоению. Характерно, что такое понимание социальной пробы и ее назначения присутствует даже в концепциях социокультурной практики, базирующихся на вполне современных представлениях о событийном характере самоопределения и саморазвития личности. Так, например, в работе В.В. Николиной говорится: «вначале учащиеся включаются в отдельные ситуации - социальные пробы, обеспечивающие им формирование первоначального соответствующего опыта» [68, с. 273]. Далее социальная проба попросту занимает свое место в ряду других средств освоения социокультурной практики: «современное образование, рассматриваемое как антропопрактика, в социокультурном контексте обес- 
печивает включение обучающихся в различные виды и способы человеческой деятельности преемственно в контексте их возрастно-нормативной модели развития в виде социальных проб, проектов, социального проектирования, социокультурных практикумов, исследовательской деятельности» [68, с. 275]. Из этого можно заключить, что социальная проба представляет собой первоначальный и, следовательно, самый низкий уровень, на котором реализуется «активная, самостоятельная поисковая деятельность» учащихся.

Если же понимать сущность социокультурной практики с точки зрения первичности субъектного опыта, развитие которого подчинено принципу амплификации (А.В. Запорожец), то социальная проба представляет собой «сквозной» механизм освоения развивающейся и разветвляющейся социокультурной практики. Особо следует подчеркнуть, что в этом случае результатом социальной пробы становится не просто вхождение ученика в новую сферу деятельности, а обретение ребенком нового опыта, который, как показал в своем исследовании Б.Д. Эльконин, становится для него инструментом для совершения последующих проб [104].

В этом случае можно выделить следующие базовые характеристики социальной пробы как творческого, смыслопорождающего действия ученика, лежащего в основе осознанного полагания им индивидуальных образовательных результатов, открывающих новые возможности освоения зоны его ближайшего развития.

Во-первых, в основании социальной пробы лежит проблемная задача, для решения которой недостаточно имеющихся у ученика познавательных и преобразовательных средств. Однако разрыв между имеющимися средствами и уровнем сложности решаемой задачи не 
должен быть виден ученику изначально. Для этого предлагаемая задача должна предъявляться ученикам не «напрямую» (как обычная учебная задача), а в виде кейса, предполагающего различные пути разрешения проблемной ситуации. При этом необходимо предусмотреть возможность «нулевого решения», для нахождения которого средств, находящихся в распоряжении учеников вполне достаточно. Задача педагога, организующего пробу, состоит в том, чтобы ученики сами обнаружили возможность принятия более интересных, креативных решений. Другими словами, ученики должны ощутить недостаточность той «разности потенциалов», между исходной и преобразованной ситуацией, которая, по словам И.А. Колесниковой характеризует подлинно проектное решение [46].

Во-вторых, социальная проба представляет собой совместное действие детей и взрослых (как минимум, учеников и педагога, возможно вовлечение в нее и других взрослых представителей социума, например, родителей учащихся, представителей профессиональных сообществ и т.д.). Обусловлено это тем, что совместный характер социальной пробы не только создает возможности взаимообучения и взаимной поддержки ее участников, но и позволяет педагогу оказывать ученикам адресную поддержку именно в тех ситуациях, когда разрыв между целями и имеющимися средствами объективно превышает возможности его самостоятельного преодоления учащимися. Одной из форм такой поддержки выступает «подсказка», которая, по выражению В.Т. Кудрявцева, нужна сильному [52]. Смысл подсказки состоит именно в том, что ей можно воспользоваться, уже овладев определенным набором способов универсальных действий, которые в конкретной 
проблемной ситуации ученику необходимо перенести в новую систему отношений.

В-третьих, социальная проба совмещает в себе две взаимосвязанные стороны: собственно преобразовательное действие, направленное на преобразование заданной ситуации, и рефлексию этого действия в сознании участников. Учащимся необходимо получить ответ на вопрос, что именно произошло с ними самими в процессе совместного решения проблемной задачи, какой новый опыт они вынесли из этого действия, и какие дефициты собственной компетентностной сферы они обнаружили? Последнее непосредственно выступает основанием для полагания индивидуальных образовательных результатов, которые необходимы для совершения последующего шага собственного развития.

Здесь необходимо следующее замечание. Личностная рефлексия, как показано в исследованиях Д.И. Фельдштейна возникает в старшем подростковом - раннем юношеском возрасте [94]. Однако это не означает, что рефлексивная социальная проба невозможна для учащихся более младших возрастных категорий. В этом случае рефлексия может быть организована педагогом в форме совместного обсуждения «специальных» вопросов: что у нас получилось лучше, а что хуже из того, что мы собирались делать? Что наиболее привлекательно и интересно в найденном решении? Какое возможно продолжение того, что нам удалось сделать? И т.д.

И, в-четвертых, социальная проба продуктивна, то есть завершается созданием продукта, опосредующего взаимоотношения ее участников с внешним социальным окружением. Созданный продукт в процессе его презентации окружающим людям выступает своего рода зеркалом, 
в котором отражается совершенное действие именно как «социально утверждаемое» (Б.Д. Эльконин).

Практическое воплощение этих концептуальных характеристик социальной пробы предполагает использование следующей методической схемы ее организации в условиях учреждения дополнительного образования. Эта схема включает три основных этапа.

Первый этап посвящен общей ориентации в осваиваемой социокультурной практике. Участникам пробы необходимо построить первоначальную смысловую картину того, что нового им открывается в ранее известной по прежнему игровому и познавательному опыту действительности. Именно схватывание общего смысла позволяет учащимся увидеть эту действительность как спектр еще не реализованных возможностей ее творческого преобразования. Средствами для этого могут выступать игры (для детей дошкольного возраста), выполнение творческих заданий (для более старших), а также проведение пилотных исследований с использованием специальных методов (наблюдение, анализ, моделирование и т.д.). Например, приглашая детей в мир народного танца, педагог может смоделировать в игровой форме исторические события и ситуации, которые отражаются в танцевальном искусстве. В ходе моделирования таких ситуаций можно предложить детям перевоплотиться в их героев, в героев прошлых времен, используя для этого выразительные средства движений тела. После этого можно соотнести собственное решение с культурными аналогами, т.е. посмотреть, как это делается «понастоящему». Крайне важно, чтобы собственная проба ребенка предшествовала прямой демонстрации таких культурных аналогов. 
В другом случае (творческие объединения естественно-научной направленности) формами таких проб могут быть проведение лабораторных опытов или же просто наблюдение за объектами живой и неживой природы.

Результатом данного этапа становится самоопределение участников совместной деятельности, реализуемое ими как выбор последующих действий на осваиваемой «территории культуры».

Второй этап посвящен разработке и осуществлению участниками оригинальных проектов, направленных на более глубокую и содержательную проработку открывшихся возможностей творческого освоения социокультурных практик. Этот этап социальной пробы состоит из нескольких подэтапов. Первый из них - подэтап целеполагания, на котором участником совместного проекта предстоит определиться, что именно они будут делать, что должно стать результатом, и в как эти результаты будут предъявлены окружающим. Необходимо также обсудить, какое значение эти результаты будут иметь для самих участников проекта, какой новый опыт обретут они в ходе этого действия.

Второй подэтап посвящен выбору и освоению ресурсов, необходимых для достижения поставленных целей. Задача педагога состоит здесь в том, чтобы подвести участников проекта к вопросам: что необходимо знать для того чтобы справиться с поставленной целью? Где и как можно получить эти знания, что для этого нужно сделать? Какие понадобятся средства и материалы для реализации предполагаемого проекта, и где находятся источники этих ресурсов, как получить к ним доступ? Кто может стать партнерами по реализации этого проекта и как с ними строить отношения (в частности, к кому можно обращаться за консультациями)? 
На следующем подэтапе необходимо спланировать предстоящую деятельность, распределить обязанности и роли. Здесь крайне важно, чтобы участники проекта добровольно приняли свои обязанности, исходя из адекватной самооценки своих сильных и слабых сторон, творческих возможностей, преимуществ и т.д.

Далее следует подэтап приведения в действие намеченных планов. Основной акцент делается на выстраивании и поддержке коммуникаций с учетом особенностей совместной деятельности детей и взрослых.

И, наконец, третий этап организации социальной пробы связан с оценкой достигаемых результатов и их презентацией. Цель данного этапа - помочь учащимся понять, что именно стало личностно значимыми результатами осуществленной деятельности. Поэтому на данном этапе организуются: 1) презентации созданных продуктов; 2) рефлексивные обсуждения достигнутых результатов и их значения для участников. Однако самое главное содержание этого этапа состоит именно в обсуждении выявленных дефицитов имеющихся в арсенале учащихся способов действий и их трансформации в полагание индивидуальных образовательных результатов.

Таким образом, можно заключить, что организация социальных проб учащихся учреждения дополнительного образования детей является эффективным педагогическим средством формирования их субъектной позиции в полагании индивидуальных образовательных результатов. Однако для этого социальная проба должна органично вырастать из субъектного опыта самого ребенка и служить для него источником новых смыслов осуществляемой деятельности. Социальная проба осуществляется учащимися в форме совместного с педагогом решения творческих задач, в процессе чего взрослый оказывает ре- 
бенку поддержку в преодолении разрывов между новыми целями освоения социокультурных практик и имеющимися у него познавательными и преобразовательными средствами. Социальная проба также представляет собой событие, в ходе которого определяется социальный контекст совершаемого совместного действия. Достигаемые результаты совершения социальной пробы становятся для учащегося предметом рефлексии, в ходе которой обнаруживаются и осмысляются дефициты собственного образовательного опыта, с устранением которых связаны перспективы освоения зоны ближайшего развития. В этом и состоит ее значение для учащихся как источника полагания индивидуальных образовательных результатов, осуществляемого в позиции субъекта проектирования индивидуальной образовательной траектории.

3.3. Технология проектирования индивидуальных результатов учащихся в процессе дополнительного образования

Проектирование индивидуальных образовательных результатов представляет собой еще не представленную в массовой практике образования совместную деятельность педагогов, учащихся, а также их родителей, подчиненную особым правилам и обладающую специфическим педагогическим значением - направленностью на формирование внутриличностной позиции учащегося как субъекта построения своей индивидуальной образовательной (в широком смысле - жизненной) траектории.

Настоящий параграф содержит описание принципов, целей и задач данного вида деятельности, ее содержания, методов и этапов, а также методические рекомендации по 
ее осуществлению в условиях учреждения дополнительного образования.

В качестве главных методологических оснований, на которых выстраивается система деятельности проектирования индивидуальных образовательных результатов учащихся в данной технологии представлены принципы диалогичности и продуктивности взаимодействия педагогов и учащихся. В первую очередь отметим, что диалог составляет основу этих взаимодействий изначально, с момента первого вхождения ребенка в образовательное пространство учреждения дополнительного образования. Именно этот диалог становится механизмом порождения событийной общности детей и взрослых, в условиях которой построение индивидуальной образовательной траектории ребенка органично встраивается в его широкий жизненный контекст. Как отмечают современные исследователи, корни этого диалога восходят к учению Сократа, для которого диалог представлялся «соприсутствием двух людей в совместном поиске истины» [8, с. 17.].

Необходимость субъект-субъектного диалога педагога и учащегося обусловлена и тем, что только в этом случае ребенку постепенно становится доступен внутренний диалог со своим собственным «другим» Я, в ходе которого выстраивание индивидуальной образовательной траектории, ориентированной на достижение личностно значимых результатов, становится его авторским проектом желаемого будущего. Такая роль внутреннего диалога отражена в учении М.М. Бахтина, для которого, как отмечал его последователь В.С. Библер, именно внутренняя диалогичность человека выступает ключом к пониманию его культурной сущности [11].

Принцип продуктивности субъект-субъектных взаимодействий педагога и ребенка также имеет глубокие фи- 
лософско-педагогические основания, далеко выводящие его за рамки простого требования создания в ходе этого взаимодействия социально значимого продукта. Данный принцип, в частности, лежит в основе концепции преобразующей педагогики, которая, как отмечает Г.Б. Корнетов, «базируется на стремлении соединить процесс образования обучающихся, развития их способностей, освоения ими знаний, умений и навыков, формирования компетенций и готовности к активной общественной жизни с прямым и непосредственным включением подрастающих поколений в процесс практической деятельности по изменению и улучшению ситуации в социуме» [49, с. 13]. Продуктивность данного взаимодействия выступает альтернативой традиционным представлениям об образовательном процессе как о трансляции учителем уже существующих, готовых знаний, подлежащих освоению со стороны учащихся. Полученное знание в таком виде не является продуктом именно творческого, субъект-субъектного взаимодействия педагога и ребенка. По этой причине проектирование индивидуальных образовательных результатов, которые еще не заданы в окончательном, завершенном виде (в отличие от единиц учебного материала, усвоение которых соответствует традиционным представлениям о «единых» образовательных результатах), в этой системе взглядов невозможно. Возможным оно становится при переходе к представлениям об индивидуальных образовательных результатах как о продукте особой совместной деятельности педагога и ребенка, проектирование и получение которого выступает неотъемлемой частью содержания образования.

Далее мы перейдем к характеристике основных компонентов технологии проектирования индивидуальных 
образовательных результатов учащихся в процессе дополнительного образования.

Целью проектирования индивидуальных образовательных результатов учащихся выступает педагогическое обеспечение осознанного построения учащимся индивидуальной образовательной траектории, приводящей его к максимуму раскрытия своих творческих способностей, достижению ближайших и перспективных целей личностного и профессионального самоопределения.

Достижение этой цели предполагает решение следующих задач:

1. Развитие у учащихся мотивации творческих достижений в интересующих их сферах социальноориентированной деятельности.

2. Включение учащихся в процесс целеполагания собственных образовательных результатов на основе свободного выбора различных видов творческой деятельности, осуществляемой совместно с другими людьми.

3. Формирование способов действий, осуществляемых на основе владения универсальными компетенциями, включая критическое мышление, креативность, коммуникабельность и готовность к сотрудничеству.

4. Осуществление психолого-педагогического сопровождения творческой деятельности учащихся, в процессе которой ими достигаются поставленные цели самообразования и саморазвития.

5. Создание ситуаций самооценки учащимися достигнутых индивидуальных образовательных результатов и рефлексии состоявшихся шагов продвижения по индивидуальной образовательной траектории.

Деятельность проектирования индивидуальных образовательных результатов учащихся в своем становле- 
нии проходит ряд закономерных этапов. Дадим их общую характеристику.

Этап 1 - изучение образовательной ситуации учащегося. Под образовательной ситуацией учащегося мы понимаем особый аспект социальной ситуации развития ребенка, в котором эта ситуация характеризуется системой его отношений с другими людьми (в первую очередь, со взрослыми), возникающих в процессе построения индивидуальной образовательной траектории. Социальная ситуация развития ребенка, в целом, определяется как «специфическое для каждого возраста отношение между ребенком и окружающей средой, отраженное в его переживаниях и реализуемое им в совместной деятельности с другими людьми» [44]. В этом смысле она задает контекст, в котором могут быть проанализирована собственно образовательная ситуация. В этой связи важно учитывать двойственный характер социальной ситуации развития ребенка. С одной стороны, ее задают внешние по отношению к ребенку ожидания и требования, которые определяют его специфическое место в обществе, с другой стороны - особенности отношения к этим ожиданиям и требованиям самого ребенка. По определению, данному Л.И. Божович, социальная ситуация развития представляет собой сочетание внутренних процессов развития и внешних условий, которое является характерным для каждого возрастного этапа [14].

Проецируя эти представления на образовательную ситуацию ребенка можно также выделить две ее главные характеристики. Первая - это требования, которые начинает предъявлять общество ребенку как участнику образовательного процесса, который, как говорил Д.Б. Эльконин, «начинает осуществлять (может, впервые в своей жизни) общественно значимую и общественно полезную 
деятельность - учебную» [109, с. 245.]. Вторая - это отношение самого ребенка к объектам и субъектам окружающей его образовательной среды.

Следует особо отметить, что соотношение этих характеристик существенно различается, когда речь идет о разных образовательных средах - формальной и неформальной. В формальной среде, где цели и содержание образования определяются безотносительно особенностей конкретного ребенка и могут лишь незначительно корректироваться в рамках «дифференцированного подхода», доминирует первая характеристика образовательной ситуации ребенка, связанная с предъявляемыми к нему требованиями. Другая сторона образовательной ситуации подчинена первой и определяется степенью готовности ребенка соответствовать этим требованиям. В неформальной образовательной среде, напротив, доминирующей выступает представленность в образовательной ситуации его собственного отношения к образовательному процессу, который строится, исходя из его образовательных потребностей. Именно этот подход к изучению образовательной ситуации ребенка в наибольшей степени отвечает специфике сферы дополнительного образования.

В силу сказанного, в основу изучения образовательной ситуации ребенка в процессе проектирования его индивидуальных образовательных результатов должны быть заложены следующие показатели: образовательные потребности, представленные в виде интересов и склонностей, его собственная оценка степени их удовлетворенности и имеющийся опыт продвижения по индивидуальной образовательной траектории.

Изучение образовательной траектории ребенка на основе выделенных показателей может осуществляться при помощи комплекса взаимодополняемых методов и 
методик. К ним, в первую очередь, относятся: опрос (интервью), сбор косвенной информации о ребенке, тест незаконченных фраз и совершение свободных творческих проб в интересующих его видах деятельности, в ходе которых могут быть выявлены сформированные ранее компетенции и уровень социальных притязаний. Особо следует подчеркнуть, что использование этого комплекса диагностических средств должно обеспечивать анализ социальной ситуации развития ребенка в ее динамике, то есть, в развитии из прошлого в будущее.

Этап 2 - целеполагание. На этом этапе педагогу совместно с ребенком необходимо наметить дальние и ближние цели продвижения по индивидуальной образовательной траектории. Главными источниками целеполагания в данном случае служат данные анализа образовательной ситуации ребенка - его интересы, склонности, а также выявленные дефициты социального опыта, препятствующие достижению желаемых целей. Главная задача педагога состоит в том, чтобы определяемые цели продвижения по индивидуальной образовательной траектории выводили ребенка из зоны его актуального в зону ближайшего развития. Для этого обсуждение ближних и дальних целей необходимо вести в контексте расширения спектра имеющихся у учащегося возможностей его творческого освоения, познания и преобразования окружающего мира.

Особо важно, что, становясь субъектом выбора целей своего образовательного продвижения, учащийся встает перед необходимостью занять особую проектную позицию, находясь в которой он не только видит себя в настоящем времени, но и в «желаемом будущем». В этой связи огромное значение имеет работа творческого воображения, которая, по словам В.Т. Кудрявцева, являясь «особым знанием», способным порождать мысль [53]. Ведь для то- 
го, чтобы определить не только ближние, но и дальние цели, учащемуся необходимо вообразить себя в субъективно новых ситуациях и социальных ролях. Поэтому наиболее эффективными здесь выступают игровые методы взаимодействия учащихся и педагогов, основанные на сочетании реалистичного и воображаемого планов совместных действий.

Этап 3 - выстраивание индивидуального образовательного маршрута, приводящего к достижению поставленных целей. Как было показано в наших предшествующих исследованиях проектной единицей такого маршрута может выступать социокультурная практика, понимаемая нами как «педагогически целесообразно организуемая предметность индивидуально-групповой деятельности учащихся, в процессе освоения которой ими при помощи обретаемых культурных, проектно-преобразовательных средств моделируются проблемно насыщенные сферы общественной жизни» [32]. Освоение такой социокультурной практики возможно только при условии занятия учащимся позиции субъекта ее творческого преобразования. Этим она отличается от обычной («дидактической») логики, в которой новое знание усваивается ребенком в уже завершенной, не требующей изменения, форме. Осваивая социокультурную практику как определенную сферу деятельности и межличностных отношений, учащийся становится автором собственного проекта, направленного на разрешения некоторой запечатленной в этой сфере культурной проблематики. В ходе построения индивидуального образовательного маршрута ученика главным становится охарактеризованный выше методологический принцип «преобразующей педагогики», о котором, в частности, говорит Г.Б. Корнетов: «С помощью этой педагогики человек может включиться в глубокий учебный цикл, 
который дает средство для критического мышления о мире, так что учение является процессом и самосовершенствования, и социальной трансформации» [49, с. 15.]. Особое значение имеет то, каким образом педагог организует знакомство учащихся с теми или иными социокультурными практиками. Вопрос «что это такое?» не должен в этом случае отрываться от двух других крайне важных вопросов: «Зачем это, в чем его значение для других людей?» и «Какое отношение это может иметь лично ко мне?». Только в этом случае конкретная задача по преобразованию избранной социокультурной практики, которую может поставить перед собой ученик, становится для него «задачей-на-смысл», а ее решение - шагом продвижения по индивидуальной образовательной траектории. Вопрос о том, из каких именно социокультурных практик и решенных проектных задач будет складываться индивидуальный образовательный маршрут ученика, не может быть решен изначально в обычной логике планирования. Более целесообразно пошаговое выстраивание этого маршрута, в котором каждая последующая социокультурная практика выстраивается с учетом результатов освоения предыдущей. Ученику должна быть предоставлена возможность самостоятельно решать, каков должен быть последующий шаг продвижения по его индивидуальному маршруту. Педагог не должен форсировать этот процесс, если ученик, удовлетворившийся полученными результатами, хочет повторить пройденный путь еще раз, стать участником аналогичного проекта, либо отказаться от дальнейшего продвижения в избранном им ранее направлении. Задача, стоящая перед педагогом значительно сложнее и содержательнее: ему необходимо «удерживать» ученика в субъектной позиции и обеспечивать конструктивность принимаемых им решений. 
Этап 4 - оценка достигнутых индивидуальных образовательных результатов. Данный этап завершает единичный цикл проектирования индивидуальных образовательных результатов учащихся. Их оценка осуществляется в двух взаимодополняющих форматах. Первый представляет собой оценку, непосредственно интегрированную в деятельность учащихся, направленную на достижение индивидуальных образовательных результатов. В данном формате предметом оценивания выступают действия, совершенные учеником на каждом этапе проектирования его индивидуальных образовательных результатов. Оценивается:

- степень выраженности потребностей и мотивов, лежащих в основе выбора индивидуальной образовательной траектории;

- их соответствие поставленным целям творческой деятельности, направленной на освоение разнообразных социокультурных практик;

- освоенные в процессе творческой деятельности способы действий и взаимодействия с партнерами;

- способность осмысленно презентовать ее результаты и защищать их в оппонирующей аудитории;

- способность рефлексировать новообразования собственного социального опыта как шаги продвижения по индивидуальной образовательной траектории.

Эти оценки фиксируются в виде экспертных баллов, определяемых на основе включенного наблюдения педагогов на разных этапах деятельности учащихся, и оформляются как компоненты индивидуального оценочного портфолио достижений каждого ученика.

Второй формат оценивания носит внешний характер и реализуется в виде образовательных событий, специально проектируемых как испытания, в ходе которых до- 
стигнутые учащимися индивидуальные образовательные результаты могут быть зафиксированы в модельных ситуациях решения предложенных творческих задач. Кроме того такие события могут организовываться на соревновательной основе, что придает им смысловую окраску самоиспытания в конкурентной среде, где обретенные компетентности выступают главным средством достижения индивидуальных и групповых целей.

В ходе образовательного события группам учащихся предлагается выполнить ряд творческих заданий, предполагающих использование широкого спектра деятельностных средств, владение которыми рассматривается как индикаторы проявления индивидуальных образовательных результатов. Особо важным условием выступает разнообразие способов индивидуального участия в совместной творческой деятельности участников группы, в результате чего каждый участник может сформировать свою индивидуальную нишу, в которой в максимальной степени могут проявиться его индивидуальные образовательные результаты. Возможность такого выбора выводит участников в рефлексивную позицию, из которой они сами могут оценить свои сильные стороны и успешно освоенные компетенции.

По своему характеру предлагаемые творческие задания представляют собой описания проблемных ситуаций, требующих их преобразования в целях устранения заложенных в них внутренних противоречий. Такие описания наиболее эффективно могут быть представлены в виде кейсов, с которыми работают участники событий в режиме индивидуально-группового проектирования.

Работа с кейсами позволяет сформировать достаточно широкое поле совместной творческой деятельности, в котором одновременно будут востребованы разнообраз- 
ные компетенции участников. Кроме кейсов участникам соревнующихся команд могут даваться более «узкие» задания, в ходе выполнения которых проявляются отдельные компетентности как индивидуальные образовательные результаты, достигнутые учащимися при реализации своих индивидуальных образовательных траекторий. В этом случае появляется возможность командного самоопределения в выборе лидеров для выполнения тех или иных заданий. Примерами таких заданий могут выступать интервью, которые участники индивидуально дают специально подготовленному интервьюеру (педагогу). При этом учащиеся непосредственно в ходе интервью решают локальные творческие задачи (выстраивание продуктивных и конструктивных коммуникаций, использование выразительных вербальных и невербальных средств общения со зрителями, «смысловое» понимание сути задаваемых вопросов, конструирование смыслоемких ответов и т.д.), в чем непосредственно и доступно для экспертного оценивания проявляются достигнутые ими индивидуальные образовательные результаты.

Еще одним таким форматом оценки выступают дебаты, участвуя в которых учащиеся проявляют свою компетентность в аргументировании и оппонировании, занятии внутренней позиции другого человека, выстраивании цепочек причинно-следственных связей и т.п. При проведении дебатов участникам образовательного событий предъявляются тезисы, которые не могут быть проинтерпретированы однозначно, и предлагается аргументировать их, занимая заданную позицию «за» либо «против». Жесткая регламентация занимаемой позиции ставит участников перед необходимостью проявить свою компетентность в понимании мыслей других людей, чьи взгляды и убеждения отличаются от их собственных. 
Приведенные примеры не исчерпывают весь спектр возможных форматов оценки индивидуальных образовательных результатов. Следует отметить, что их проектирование также может непосредственно вписываться в содержание образования, осваиваемое учащимися в ходе проектирования индивидуальных образовательных траекторий. Особо важно, что участие в таких оценочных процедурах становится для учащихся фактором развития их субъектности в образовательном процессе учреждения дополнительного образования, поскольку презентация и оценка достигнутых индивидуальных образовательных результатов сами по себе становятся для учащихся творческой задачей, решаемой в логике авторского проекта собственного продвижения к намеченным целям. В этой связи представляется целесообразным предоставлять учащимся возможность выбора сроков и конкретных форматов оценки их индивидуальных образовательных результатов с их субъектным участием.

Как было сказано выше, охарактеризованные компоненты технологии проектирования индивидуальных образовательных результатов учащихся наиболее успешно могут быть реализованы в процессе дополнительного образования, мало стесненном жесткими регламентами.

3.4. Теоретические основания и методическая схема оценки индивидуальных образовательных результатов учащихся в процессе дополнительного образования

В завершающих параграфах мы более подробно рассмотрим технологию оценки индивидуальных образовательных результатов учащихся в процессе дополнительного образования и возможность проведения на этой ос- 
нове мониторинга их продвижения по индивидуальной образовательной траектории.

Оценка индивидуальных образовательных результатов имеет важнейшее значение в системе деятельности по их проектированию самими учащимися. Одной из «стержневых» выступает здесь идея развития ученика как субъекта образовательной деятельности, к чьей компетенции относится не просто усвоение учебного материала, а целеполагание самого себя в процессе выстраивания индивидуальной образовательной траектории [41]. С этой точки зрения главной функцией оценки индивидуальных образовательных результатов выступает регуляция процесса продвижения субъекта по индивидуальной образовательной траектории, а для этого необходимо учитывать, что именно оценка является системообразующей функцией психики субъекта [76].

Центральная идея, заложенная нами в основу модели оценки индивидуальных образовательных результатов учащихся в процессе дополнительного образования, связана с реализацией принципа событийности. Принцип событийности в образовании в самом общем виде может быть сформулирован следующим образом: образование как процесс взращивания «человеческого в человеке», призвано обеспечить событийность бытия каждого индивида, открыть ему возможности самореализации в поступке и совместного с другими людьми порождения смыслов своего бытия. Далее, переходя к более конкретному обсуждению образовательного события, сразу же отметим, что, как было показано в наших ранее проведенных исследованиях, это понятие еще недостаточно укоренено в тезаурусе педагогики [22]. Чаще всего оно встречается в словаре педагогов-практиков, представляющих инновационное образовательное сообщество, когда ими 
презентуется инновационный опыт реализации моделей индивидуализированного образования. В этом контексте образовательное событие выступает, наряду с проектированием вариативных образовательных сред и осуществлением тьюторского сопровождения учащихся, инновационным средством индивидуализации образования.

Использование образовательного события как формата оценивания индивидуальных образовательных результатов имеет значительное преимущество. Однако для их реализации необходимо принять следующее правило: образовательное событие не должно сводиться только к демонстрации образовательных достижений учащихся. В этом случае может лишь ретроспективно оцениваться уже пройденный путь, уже состоявшийся этап индивидуальной образовательной траектории ребенка. Истинная же цель образовательного события состоит в оценке вновь обретенных возможностей, задающих зону ближайшего развития учащегося. Поэтому демонстрация полученных образовательных результатов не должна ограничиваться презентацией созданных продуктов. В ходе образовательного события необходимо создавать ситуации, в которых проявятся именно те новообразования опыта учащихся, которые «отвечают» за дальнейшее образовательное продвижение и служат предпосылками достижения новых уровней готовности к освоению новых социокультурных практик в ближайшей и отдаленной перспективе.

В этой связи образовательное событие, нацеленное на оценку индивидуальных образовательных результатов должно содержать в себе как смысловое «ядро» творческую задачу, не дублирующую те, которые уже прежде решались участниками творческого объединения в ходе осуществленных проектов. Эта задача должна обладать определенной степенью новизны для учащихся, но обре- 
тенный ранее опыт должен выступать гарантией того, что эта задача будет успешно и креативно решена ими совместно здесь и сейчас. Такой задачей может быть разработка оригинального проекта по решению проблемной ситуации, описанной в предлагаемом кейсе; совершение виртуального образовательного путешествия, посвященного поиску ответа на поставленный проблемный вопрос; постановка импровизированного миниспектакля на заданную оригинальную тему; проведение миниисследования и т.д. Основной принцип оценки индивидуальных образовательных результатов учащихся состоит в том, чтобы в процессе их совместной деятельности в заданной ситуации зафиксировать деятельностное проявление, свидетельствующее об их способности адекватно понимать смысл решаемой задачи, грамотно определять средства и способы ее решения, компетентно обращаться к необходимым для этого ресурсам (включая информационные), строить продуктивные коммуникации и уметь презентовать и отстаивать полученные решения.

Важным условием эффективности оценки индивидуальных образовательных результатов в формате образовательного события выступает его грамотно организованное экспертно-аналитическое сопровождение. С этой точки зрения экспертиза является неотъемлемым компонентом тьюторского сопровождения совместной творческой деятельности учащихся. Важно отметить, что эта экспертиза должна носить открытый характер, к участию в ней необходимо привлекать не только педагогов, но и различных представителей социума, имеющих отношение не только к образованию, но к широкому спектру актуальных проблем жизни современного общества. Не менее важно и то, что собственно оценка образовательных результатов не должна полностью исчерпывать собой зада- 
чи и содержания образовательного события. В первую очередь это свободное творческое общение разных людей, событийность которого обусловлено их общей сопричастностью к важным процессам, лежащим в основе современной жизни. Учащимся важна не сама по себе оценка «хорошо - плохо, правильно - неправильно», а обратная связь с экспертами, посредством которой они смогут выделить для себя самое главное, что, по сути, характеризует их достижения, и наметить перспективы дальнейшего развития.

Таким образом, можно выделить три главных компонента образовательного события как формата оценки индивидуальных образовательных результатов учащихся. Во-первых, это совместное решение оригинальных творческих задач, в ходе чего проявляется их компетентность в совместном освоении новых социокультурных практик. Во-вторых, это экспертно-аналитическое сопровождение, в ходе которого выявляются и оцениваются конкретные компетенции, лежащие в основе готовности учащихся к проектированию индивидуальной образовательной траектории. Спектр этих показателей должен соответствовать структуре и содержанию этой готовности, включая не только конкретные способы действий, необходимые для решения творческих задач, но и характеристики их мотивации, ценностно-смыслового отношения к осуществляемой деятельности именно как к образовательному продвижению, а также способность достигать намеченные цели этого продвижения. И, в-третьих, это свободное творческое общение разных людей, для которых получение качественного образования выступает их целью. Именно такое общение выступает главным условием освоения учащимся внутренней позиции субъекта 
проектирования

индивидуальной образовательной траектории.

В этой связи может быть предложена методическая схема подготовки и проведению Фестиваля творческих достижений учащихся, не только как формата оценки индивидуальных образовательных результатов учащихся, но и как стартовой площадки для выбора последующих социокультурных практик, уровня их освоения и, в целом, определения дальнейших шагов по проектированию индивидуальной образовательной траектории.

При подготовке Фестиваля необходимо решить следующие задачи. Во-первых, нужно проанализировать данные мониторинга развития творческой деятельности учащихся и содержания реализованных проектов. На этом основании нужно выделить проблематику, на разрешение которой будут направлены творческие задания для участников Фестиваля.

Во-вторых, организаторам Фестиваля требуется разработать и апробировать пакет таких творческих заданий, соответствующих выявленной приоритетной проблематике. Задание сообразно подготовить в виде кейсов. Кейс должен содержать описание некоторой проблемной ситуации, требующей принятие оригинального проектного решения и непосредственно формулировку творческих заданий к этому кейсу. Например, таким кейсом может служить описание местности или конкретного пункта, куда участникам Фестиваля предстоит отправиться в образовательное путешествие. Целесообразно «зашифровать» эту местность таким образом, чтобы участникам потребовалось установить цель своего путешествия на основе представленной косвенной информации (географические координаты, упоминание происходивших там исторических событий, указание известных имен, связанных с этой 
местностью и т.д.). Сами же творческие задания (что именно предстоит сделать участникам образовательного путешествия) должны быть связаны с предпочитаемыми ими видами деятельности, отвечающими направленности конкретных творческих объединений, в которых участники осуществляли ранее свою образовательную траекторию. Там, где речь идет о художественнотворческой направленности, такие задания могут быть связаны с постановкой импровизированных спектаклей, которые могут иметь успех у местных жителей, созданием художественных текстов и композиций, исполнением народных танцев, отвечающих этнокультурным особенностям данной местности и т.д. и т.п. В случае социальногуманитарной направленности такие задания могут состоять в разработке оригинальных проектов, ориентированных на решение актуальных проблем жизни местных сообществ. Для спортивной направленности возможны творческие задания, состоящие в проведении соревнований по экзотическим видам спорта, популярным в данной местности.

Необходимо учесть, чтобы эти кейсы были привлекательны для участников объединения и мотивировали их на принятие креативных решений.

В-третьих, следует подготовить команду экспертов и оснастить ее необходимым инструментарием. При этом следует учитывать, что экспертам предстоит оценивать индивидуальные образовательные результаты учащихся как освоенных средств продуктивного освоения социокультурных практик, собственных регулятивных и коммуникативных способностей и готовности к принятию решений, отражающих ценностно-смысловые ориентации авторов проектов в заданной проблемной ситуации. Необходимо добиться точного понимания экспертами того, что 
именно им предстоит оценивать и обеспечить их готовность использовать подготовленные экспертнооценочные инструменты. Сами эти инструменты должны быть достаточно просты в использовании, но при этом необходимо обеспечить четкое и однозначно понимаемое соответствие выставляемых баллов и их качественных интерпретаций.

В-четвертых, организаторам Фестиваля предстоит разработать его программу с учетом не только интересов его участников, но и возможностей разнообразия форматов их общения, в которых могут быть заложены точки их дальнейшего роста. Необходимо добиться, чтобы Фестиваль представлял собой калейдоскоп разных маленьких событий, но при этом сохранял свою целостность и не сводился к шоу, единственное назначение которого состоит в том, чтобы развлечь участников. В этой связи желательно предусмотреть интерактивные, неподготовленные заранее эпизоды творческого взаимодействия участников, предполагающие активное использование импровизации. Такими эпизодами могут быть интервью, неформальное общение с экспертами, предъявление неожиданных творческих заданий, в целом, создание ситуаций, когда участникам фестиваля нужно творчески действовать «здесь и сейчас», оперативно решая различные творческие задачи.

В-пятых, необходимо предусмотреть информационно-аналитическое сопровождение Фестиваля и оперативное размещение его материалов на сайте образовательного учреждения и других информационных ресурсах. Для этого целесообразно подготовить группу аналитического сопровождения из числа педагогов, приглашенных внешних партнеров и учащихся старшего возраста, не являющихся непосредственными участниками команд, пред- 
ставляющих результаты своей творческой деятельности. При этом важно обеспечит оперативную подготовку видео- и фотоматериалов. Программа Фестиваля не должна быть жестко подчинена какому-либо раз и навсегда уставленному шаблону. Приветствуется вариативность и разнообразие форматов совместной деятельности его участников. Однако при этом следует подчинить это разнообразие некоторым общим правилам, отражающим общую логику этого совместного творческого действия именно как креативного формата оценки индивидуальных образовательных траектории учащихся.

Прежде всего, необходимо обеспечить возможности активного включения в осуществляемое совместное действие всех его участников. Роль «пассивного зрителя» должна быть сведена к минимуму. Для этого в ходе проведения Фестиваля обустроить несколько рабочих пространств, в которых одновременно будут осуществляться различные совместные действия участников. Такими рабочими пространствами могут быть: сценическая площадка, различные мастерские, подиум для демонстрации моделей костюмов, исследовательская лаборатория и т.д. Их необходимо оснастить разнообразными материалами, которые могут быть использованы в ходе реализации различных проектов (костюмы, реквизит, ширмы для изготовления декораций, бумага, картон, краски и прочие расходные материалы, канцелярские принадлежности и другие материалы, инструменты, ноутбуки, разнообразный инвентарь, зеркала и прочие материалы, необходимые для реализации проектных решений). Оснащение рабочих пространств должно обеспечивать избыточность средств, которые могут использовать участники творческой деятельности для осуществления различных креативных решений. Особое значение имеет доступность ин- 
формационных ресурсов, включая свободный выход в интернет.

Что же касается непосредственного предъявления созданных в ходе образовательного события продуктов необходимо также предусмотреть разнообразные креативные форматы этого итогового действия. Традиционный вариант выступления перед членами жюри не является здесь наиболее оптимальным, поскольку креативное решение проектной задачи предполагает использование креативных способов его презентации. Поэтому наиболее целесообразно не задавать жестко способ презентации полученных результатов, а предоставить участникам возможность продуцирования и реализацию собственных идей.

Для того чтобы помочь участникам Фестиваля максимально использовать имеющиеся у них возможности и с учетом того, что уровень неопределенности ситуации при этом достаточно высок, педагогам, участвующим в проведении Фестиваля, следует взять на себя функции модераторов деятельности участников, которые, не навязывая им собственных решений, в то же время стимулировали бы их поиск максимально творческих решений.

Таким образом, оценка индивидуальных образовательных результатов учащихся в формате Фестиваля творческих достижений представляет собой совместное разветвленное креативное действие множества субъектов, результатом которого становится не просто формальная оценка достижений, а одновременное проявление различных сторон и аспектов этих результатов в достаточно неопределенной ситуации, требующей от участников максимальной мобилизации имеющихся у них средств решения творческих задач. 
3.5. Мониторинг индивидуальных образовательных достижений учащихся как условие эффективности процесса дополнительного образования

Мониторинг в образовании в последнее время стал неотъемлемой частью управления образовательными учреждениями. Он рассматривается, в первую очередь, как эффективный инструмент управления качеством образования. Этой теме посвящено значительное количество публикаций. (Н.М. Борытко, О.В. Бурляева, С.А. Елистратов, А.М. Моисеев, А.М. Саранов и др.). Главным назначением мониторинга в современных социокультурных условиях становится контроль реализации Федеральных государственных образовательных стандартов. Это обстоятельство во многом отличает его от аналогов прошлых времен, где акцент делался на педагогической диагностике процессов развития учащихся и формирования их личностных качеств (В.С. Ильин, А.И. Кочетов, Н.И. Монахов и др.). В настоящее время сформирован спектр достаточно распространённых и устойчивых представлений о сути, назначении и способах реализации мониторинга в сфере образования. Большинство авторов сходятся на том, что назначение мониторинга как инструмента стратегического управления состоит не только в отслеживании, но и в своевременной коррекции отклонений от намеченных целей. Как отмечает в своем исследовании С.А. Елистратов, «сущность мониторинга качества образования - это сбор, обработка, хранение и распространение достоверной информации о качестве образовательных результатов, условиях и цене их достижения, а также ее анализ и интерпретация» $[29$, с. 49]. Мониторинг в данной трактовке - это средство управления качеством образования, основными компонентами которого являются: контроль и диагности- 
ка; сбор данных и оценка; действия (принятие соответствующих мер). Согласно определению, предложенному А.М. Моисеевым, «мониторинг предполагает постоянное слежение за фактом и качеством выполнения действий, предусмотренных стратегическими планами и программами, фиксацию достижения запланированных показателей промежуточных и итоговых результатов» [67, с. 63].

Таким образом, можно отметить стремление исследователей и управленцев вместить в понятие «мониторинг» весь спектр функций, действий и средств, обеспечивающих всесторонне и комплексное отслеживание образовательного процесса и его результатов в соответствии с требованиями ФГОС. При этом и процесс, и результаты мыслятся как нечто целостное, а вариативность и разнообразие возможных методов и форм мыслятся лишь как условия, которые необходимо учитывать при определении конкретных мониторинговых действий.

В то же время ряд авторов отмечают трудности в проведении мониторинговых исследований, выходящими за пределы требований ФГОС. В первую очередь такие затруднения испытывают педагоги и менеджеры образовательных учреждений, работающих на основе авторских педагогических технологий, таких, как, например, система развивающего обучения В.В. Давыдова - Д.Б. Эльконина [1]. С иными, не менее важными затруднениями в проектировании и организации мониторинговых исследований сталкиваются педагоги дополнительного образования, поскольку образовательные результаты в этой сфере до сих пор не стандартизированы, а попытки распространить требования ФГОС на деятельность учреждений дополнительного образования чреваты утратой ее креативного потенциала для индивидуального развития ребенка. Так, в нашем исследовании, посвященном обоснованию педа- 
гогической технологии проектирования индивидуальных образовательных результатов учащихся в системе дополнительного образования, установлено, что мониторинг таких результатов может осуществляться только на иных, отличных от «стандартоориентированных» основаниях.

Цель проведенного исследования состояла в анализе существующих подходов к организации мониторингов образовательных результатов учащихся и обоснованию модели мониторинга, отвечающей специфике и сущности индивидуализированного процесса дополнительного образования.

Проведенный анализ научной литературы и методических материалов позволил выделить базовое противоречие, лежащее в основе выбора стратегий и технологий мониторинговых исследований в образовательных учреждениях разного типа. Это противоречие связано с понятиями контроля и экспертизы, выступающими в данном случае двумя альтернативными стратегиями мониторинга.

Первая, «контролирующая» стратегия базируется на внешних по отношению к контролируемому процессу нормах, отражающих его заданное, эталонное состояние. Как отмечает в своем исследовании Н.М. Борытко, «контроль как вид управленческой деятельности связан с сопоставлением определенных нормативных показателей с показателями, фиксируемыми различными способами в ходе изучения управляемого процесса на определенных этапах» $[15$, с. 22]. Технология мониторинга в этом случае призвана обеспечить соответствие реальных характеристик процесса и его результатов заданной норме на всех его этапах: «При рассмотрении мониторинга с позиций технологии приходится, однако, акцентировать внимание на первостепенное выделение критериев оценки исходно- 
го, промежуточных и конечного состояний объекта, логики этапов процесса, а также показателей его динамики» $[15$, c. 24].

Попытки применить данную стратегию к мониторингу индивидуальных образовательных результатов неизбежно приводят к тому, что субъектность учащихся в этом процессе ограничивается теми самыми внешне заданными нормами, которые изначально формируются без учета индивидуальных образовательных потребностей и собственных целей субъекта. Так, по утверждению О.В. Бурляевой и М.П. Мироновой, «мониторинг образовательных результатов предполагает периодический контроль освоения образовательной программы, направленный на определение соответствия индивидуальных образовательных достижений обучающихся и выпускников требованиям потребителей образовательных услуг и заданным эталонам (стандартам)» [18, с. 21]. Нетрудно заметить, что сам термин «индивидуальный» обозначает лишь отклонение достигнутого субъектом результата от заданного требования, которое рассматривается не как ее нарушение, а как своего рода «вариация на заданную тему». Несколько парадоксальным в этом смысле выглядит утверждение о том, что «в первую очередь контроль направлен на выявление продвижения учащихся по образовательной траектории». Эта парадоксальность связана с тем, что ключевое слово «потребитель», каковым является студент по отношению к предоставляемым образовательным услугам низводит его индивидуальную образовательную траекторию до уровня формального выбора из числа предлагаемых компонентов содержания образования. Характерно, что в данном случае «результаты освоения образовательных программ выражаются через готовность к выполнению определенного вида профессиональ- 
ной деятельности...» $[18$, с. 21]. В чем же собственно проявляется индивидуальный характер этой готовности, авторы не уточняют.

Реализация данной стратегии на практике чаще всего приводит к тому, что индивидуальные образовательные достижения учащегося рассматриваются как некое дополнение к основному «стержню», не имеющее самостоятельного значения. Так, например, нередко можно встретить понятие «портфолио успешной карьеры», которое «является формой оценивания индивидуальных образовательных достижений, инструментом профессионального самоопределения и формирования индивидуальной траектории развития обучающихся 9-11х классов». Однако содержание такого портфолио представляет собой лишь набор данных, характеризующих «профессиональную предрасположенность обучающегося, схему профессионального планирования, исследование возможностей получения образования для приобретения профессиональных навыков, индивидуальный учебный план» [23, с. 33]. Таким образом, индивидуальные образовательные результаты как собственные достижения учащегося, полученные им в процессе творческого освоения действительности, практически не отражаются, а смысл выделения оценки индивидуальных достижений в самостоятельный компонент образовательного мониторинга сводится, в основном, к выделению профессионализации в отдельный процесс, мало связанный с освоением основного содержания образования.

В целом же, можно утверждать, что «контролирующая» стратегия образовательного мониторинга характеризуется отчужденностью субъекта от проектирования индивидуальной образовательной траектории. 
Принципиально другая стратегия мониторинга связана с доминированием экспертного подхода к оценке индивидуальных образовательных результатов учащихся. Соответствующее этой стратегии понимание сущности образования (в данном случае, высшего) принадлежит П.Г. Щедровицкому. Под образованием он, в первую очередь, понимает инструмент культурной политики, назначение которого состоит в передаче человеку определенного набора культурных норм, ориентируясь на которые он выстраивает свои действия (именно в этом главным образом проявляется его субъектность). Соответственно и образовательные результаты трактуются им принципиально иначе: не готовность к осуществлению функции, а кругозор («понимание того, что мир большой, что в нем много чего происходит...») и стиль («умение коммуницировать, слушать, понимать разные позиции, разные точки зрения, видеть их основания») [103, с. 14]. Отметим, что такой подход к пониманию образовательных результатов изначально основан на принятии их индивидуальной сущности как средств, при помощи которых человек самостоятельно решает обнаруживаемые им в проблемном поле культуры «задачи-на-смысл».

В данном контексте необходимо рассмотреть еще две модели образовательного мониторинга, в которых собственно контролирующей функции отведено далеко не центральное место. Первая из них ориентирована на мониторинг результатов воспитания. Невозможность использовать в данном случае «контролирующую» стратегию обосновывает, в частности, Н.М. Борытко, обращая внимание на следующие особенности этого процесса [15].

Во-первых, результативность воспитания («воспитательные эффекты»), как правило, нельзя установить на 
основе линейной причинно-следственной зависимости «стимул - реакция».

Во-вторых, в воспитании нет шаблона, инвариантного эталона.

В-третьих, в отличие от обучения как функциональной подготовки воспитание обращено к целостному человеку и оцениваться может лишь в логике качественных изменений.

В-четвертых, воспитание принципиально отличается от прочих объектов диагностики тем, что в нем субъективность не является нежелательным явлением.

B-пятых, следует учитывать три аспекта воспитания: социальный (принятие ценностей среды, формирование чувства сопричастности), индивидуальный (выделение себя из среды: самоопределение, самостановление, самореализация... и прочие «само...», которые определяют самоценность человека в жизни и деятельности) и коммуникативный.

Исходя из этих особенностей, автор делает общий вывод о том, что «при диагностике, анализе и оценке результативности воспитания основными следует рассматривать не количественные показатели (проведенные мероприятия, переданные знания, сформированные умения, взгляды и т. д.), а получение иного качества педагогического процесса, которое реализуется одновременно в его субъектах (педагоге и воспитаннике) и предмете их совместной деятельности (педагогическом взаимодействии)» $[15$, c. 25]. Полностью разделяя эти взгляды, все же отметим, что в данном случае продвижение ребенка по индивидуальной образовательной траектории полностью замыкается на его взаимодействия с педагогами, что несколько сужает рамку понимания его индивидуальных 
образовательных результатов и его самого как субъекта их проектирования.

Вторая альтернативная модель мониторинга в качестве своего объекта имеет не образовательный процесс как таковой, а систему условий, в которых порождаются и реализуются отношения между его субъектами. В исследовании П.А. Кислякова такой подход к мониторингу образовательной среды назван «экопсихологическим». Роль учащихся как субъектов образовательных отношений, активно взаимодействующих с компонентами окружающей среды выступает в данном случае изначальной. В частности, автор отмечает: «Обучающийся своими действиями и поступками активизирует элементы образовательной среды и тем самым конструирует ее для себя. При этом у него формируется некий «психический образ» среды..., который дает ему возможность действовать определенным образом» [38, с. 44]. В то же время предлагаемые автором подходы к экопсихологическому мониторингу образовательной среды, на наш взгляд, недостаточно отражают именно этот принцип первичности субъекта, поскольку объекты мониторинга представляют собой именно характеристики самой среды (ее комфортность / враждебность для субъекта, содержащиеся в ней риски и т.д.). Но при этом фактически не предпринимаются попытки осуществлять ее мониторинг по показателям образовательных достижений субъекта, на которые данные средовые условия оказали формирующее влияние. Другими словами, готовность субъекта определенным образом действовать в образовательной среде лишь косвенно выступает здесь объектом мониторинга.

Таким образом, существующие стратегии мониторинга в образовании не соответствуют полностью задаче непрерывного отслеживания индивидуальных образова- 
тельных результатов учащихся и управления на этой основе индивидуализированным образовательным процессом. В нашем исследовании, посвященном обоснованию проектирования индивидуальных образовательных результатов как совместной творческой деятельности учащихся и педагогов дополнительного образования, предложена модель мониторинга этих результатов, основанная на понимании их сущности как самостоятельно осуществленных шагов учащихся по их индивидуальной образовательной траектории. Каждый такой шаг сопровождается обретением новых смыслов, освоением новых способов действий и получением субъектного опыта социального утверждения (термин Б.Д. Эльконина [104]), осуществляемого в новых форматах взаимодействия субъекта с окружающими людьми. Эти три стороны целостного индивидуального образовательного результата, как было показано выше, и выступают объектами мониторинга.

Исходя из этих представлений, в основу мониторинга закладываются следующие показатели: мотивация достижений, самооценка, освоенные способы действий и уровень их социального утверждения. Дадим их краткую характеристику.

Мотивация достижений и самооценка выступают косвенными характеристиками смыслового компонента индивидуального образовательного результата учащегося. Необходимость использования косвенных характеристик обусловлена невозможностью «напрямую» диагностировать обретенные учащимися в процессе творческой деятельности смыслы. В то же время во многих психологических исследованиях авторы отмечают, что мотивация достижений (в отличие от мотивации избегания неудач) выступает коррелятом смыслопоисковой активности. Так, А.В. Брушлинский [17] и В.П. Зинченко [30] утверждали, 
что ребенок, мотивированный на решение творческой задачи в момент нахождения этого решения испытывает «творческое озарение», что напрямую свидетельствует об обретении им личностного смысла. Г.И. Марасанов и Н.А. Рототаева обосновали мотивацию в качестве косвенного показателя процесса личностного самоопределения [63], суть которого, как отмечает, в частности, Н.С. Пряжников, составляет поиск смысла [81]. В ходе мониторинга оценку мотивации достижений целесообразно осуществлять не при помощи стандартизированных психодиагностических методик, а на основе более мобильных средств педагогической диагностики. Связано это с тем, что проявления мотивации необходимо фиксировать непосредственно в ситуации совместной творческой деятельности учащихся, именно тогда она в наибольшей степени связана со стремлением решить проблему как личностно значимую «задачу-на-смысл». В нашем опыте апробации описываемой модели на базе Центра дополнительного образования «Хоста»г. Сочи использовался следующий диагностический прием. Приходя на занятие, учащиеся выбирали флажок определенного цвета. По достигнутой ранее договоренности с педагогом избираемые цвета означали:

- желтый: я испытываю сильное желание хорошо поработать и получить важный результат;

- зеленый: надеюсь провести время интересно и с пользой для себя;

- белый: раз уж я здесь, попробую чем-нибудь заняться;

- синий: особого желания что-либо делать я не испытываю, лучше просто отдохнуть;

- черный: если бы меня не заставили, я бы сегодня вообще не пришел. 
Самооценка также выступает косвенным показателем смыслового компонента индивидуального образовательного результата. В этом случае она должна быть оперативной и отражать степень удовлетворенности учащегося достигнутыми результатами. Этот показатель нужно использовать для мониторинга учащихся более старшего возраста, поскольку, как показывают исследования Д.И. Фельдштейна, оперативная самооценка является психическим новообразованием подросткового возраста [94]. Поэтому использование стандартизированных психодиагностических методик здесь также не является целесообразным. Инструментом педагогической диагностики для сбора данных мониторинга могут служить «смайлики», которые выбирают учащиеся в конце каждого занятия. Они могут обозначать следующие варианты ситуативной самооценки: «я очень доволен тем, что сделал сегодня», «в целом, все получилось неплохо»; «я надеялся на большее»; «сегодня - не мой день, я не доволен тем, что у меня получилось».

Оценка и сбор данных о способах действий, освоенных учащимися в ходе решения творческих задач, в предложенной модели осуществляются на основе экспертных методов в событийно-деятельностном формате образовательного события. В ходе этих событий моделируются ситуации совместного решения учащимися творческих задач и проводятся индивидуальные презентации продуктов творческой деятельности. Предметом оценивания и фиксации в базе данных мониторинга в первом случае (в ситуации решения задачи «здесь и сейчас») становятся уровни эффективности использования учащимися освоенных ранее способов действий в процессе решения творческих задач. Первый уровень характеризуется способностью применить определенный способ действия в задан- 
ной ситуации, где условия задачи сформулированы в виде последовательности конкретных заданий, гарантированно приводящей к решению. На втором уровне учащиеся проявляют способность решать поставленную задачу, самостоятельно определяя способ ее решения и последовательность необходимых шагов. На третьем уровне учащимся необходимо самим сформулировать проектную задачу, исходя из данного им описания проблемной ситуации, и после этого определить и применить адекватные способы действий. Для оценки конкретных способов действий, осуществляемых при совместном выполнении заданий разного уровня (понимание и «удержание» смысла решаемой задачи, использование схематизации, продуцирование идей, культура обращения к теоретическим знаниям, коммуницирование с партнерами, рефлексия и т.д.) педагогами дополнительного образования используются специальные экспертные карты, где уровни овладения ими интерпретируются в баллах. Эти балльные оценки и заносятся в базу данных мониторинга по каждому учащемуся.

Во втором случае (индивидуальная презентация и защита созданного продукта) освоенные учащимися способы действий оцениваются на основе экспертизы самого продукта и по показателям компетентности его презентации. При этом важно, что решение об участии учащихся в мониторинговых процедурах принималось ими самостоятельно на основе самооценки собственной готовности в наличной ситуации продвижения по индивидуальной образовательной траектории.

И, наконец, мониторинг освоенных учащимися способов социального утверждения осуществленных продуктивных действий базируется на следующих уровневых характеристиках. Первый уровень характеризуется стрем- 
лением учащихся получить признание социальной значимости совершенного продуктивного действия в виде одобрения и поддержки со стороны значимых других людей - и педагогов, и сверстников, и родителей и т.д. Сами же они при этом не проявляют особой активности и ожидают, что такое признание придет само собой. На втором уровне учащиеся проявляют готовность активно взаимодействовать с представителями окружающего социума, презентуя, «продвигая» и отстаивая достигнутые результаты (например, выступая перед оппонирующей аудиторией). На третьем же уровне учащиеся проявляют стремление придать вновь обретаемый социальный опыт другим людям, занять при этом новые для себя позиции наставника, ментора и т.д.

Фиксация этих данных может осуществляться в специально создаваемых педагогами дополнительного образования ситуациях свободных социальных проб непосредственно в ходе проводимых образовательных событий.

В заключение отметим два важных отличия предлагаемой модели от традиционных методов и форм образовательного мониторинга. Первое - это отсутствие жесткой связи «цель - отклонение - коррекция», присущей моделям мониторинга, основанных на контроле требуемых результатов. В нашем случае фиксируемый результат не соотносится с заранее заданным эталоном, а отражает индивидуальное «приращение» социального опыта субъекта (например, его выход на более высокий уровень осуществляемого действия). Во-вторых, обязательным условием эффективности мониторинга индивидуальных образовательных результатов выступает субъектная включенность учащихся и родителей в мониторинговые процедуры и оценку качества полученного учащимся образования. 
В то же время необходимо заметить, что данная модель может быть реализована лишь в том случае, если образовательный процесс учреждения дополнительного образования выстраивается на основе проектирования индивидуальных образовательных траекторий учащихся, реализуемых ими как последовательности значимых образовательных событий, в основу которых заложено совместное решение творческих задач. В процессе решения этих задач могут проявляться именно те образовательные результаты, которые в полной мере характеризуют индивидуальные достижения каждого учащегося.

\section{Выводы по третьей главе}

Эффективность индивидуализированного образовательного процесса, в котором субъектом осуществляется полагание индивидуальных образовательных результатов учащихся, обеспечивается необходимыми для этого педагогическими условиями: возможность свободного выбора осваиваемых социокультурных практик и целей их творческого преобразования; разнообразие социальноролевых позиций, которые могут занимать участники творческих проектов; сочетание реалистичного и воображаемого планов совместной творческой деятельности субъектов освоения социокультурной практики; включение в структуру совместной деятельности субъектов освоения социокультурной практики ситуаций индивидуальной и групповой рефлексии.

Наиболее эффективным средством формирования у учащихся позиции субъекта проектирования индивидуальных образовательных результатов выступает организация свободных социальных проб. Базовыми характеристиками таких проб выступают: постановка проблемной 
задачи, для решения которой недостаточно имеющихся у ученика познавательных и преобразовательных средств; организация пробы как совместного действия детей и взрослых; единство собственно преобразовательного действия и рефлексии этого действия в сознании участников; создание продукта, опосредующего взаимоотношения ее участников с внешним социальным окружением.

Технология проектирования индивидуальных образовательных результатов учащихся включает в себя следующие компоненты: цель, состоящую в педагогическом обеспечении осознанного построения учащимся индивидуальной образовательной траектории, приводящей его к максимуму раскрытия своих творческих способностей и задачи ее реализации; этапы - изучения образовательной ситуации учащегося, совместного с учеником целеполагания его продвижения по индивидуальной образовательной траектории, выстраивания индивидуального образовательного маршрута, приводящего к достижению поставленных целей, оценки достигнутых индивидуальных образовательных результатов.

Оценивание индивидуальных образовательных результатов учащихся представляет собой совместное разветвленное креативное действие множества субъектов, результатом которого становится не просто формальная оценка достижений, а одновременное проявление различных сторон и аспектов этих результатов в достаточно неопределенной ситуации. Такая оценка лежит в основе мониторинга индивидуальных образовательных достижений учащихся, который выступает важным условием эффективности процесса дополнительного образования. 


\section{ЗАКЛЮЧЕНИЕ}

Представление об индивидуальном образовательном результате учащегося как о шаге его продвижения по индивидуальной образовательной траектории, совершение которого сопровождается порождением личностных смыслов, освоением новых способов действий и их социального утверждения, формируется в контексте общего принципа индивидуализации образования. Значение индивидуального образовательного результата для самого субъекта состоит в расширении пространства его творческих возможностей, круга проблемных задач, которые он может решать самостоятельно, взаимодействуя при этом с другими людьми, строя с ними отношения сотрудничества в команде. В проведенном исследовании это положение обосновано на методологическом, теоретическом и методическом уровнях. Методологические основания модели проектирования индивидуальных образовательных результатов учащихся сопряжены с философским взглядом на сущность этой деятельности как особую форму отношения развивающегося человека к окружающему миру и самому себе в этом мире. Самодвижение и устремленность в будущее выступают для субъекта проектирования собственных образовательных результатов культурной нормой, имплицитно представленной в базовых стратегиях его жизни, личностного и профессионального самоопределения. С позиций психологии эта деятельность может быть рассмотрена как особая форма поиска смысла, побуждающего субъекта к выбору и освоению неадаптивных стратегий саморазвития, внутренней позиции «хозяина жизни» и «автора собственной судьбы». В социальнопедагогическом контексте проектирование индивидуальных образовательных результатов было рассмотрено в 
проведенном исследовании как новая социальная и образовательная реальность, представляющая собой качественно новый шаг в развитии научных представлений о субъект-субъектных взаимодействиях, осуществляемых в формальных и неформальных образовательных средах.

Построенная в ходе проведенного исследования теоретическая модель проектирования индивидуальных образовательных результатов учащихся в процессе дополнительного образования базируется на понимании сущности этих результатов как реализованном в субъектном опыте ребенка его «запроса к Культуре». С этой точки зрения индивидуальный образовательный результат представляет собой ответ на запрос, самостоятельно полученный ребенком в процессе его погружения и творческого освоения разнообразных социокультурных практик. Сами же эти практики характеризуются высокой степенью их проблемной насыщенности, неопределенностью ситуации их творческого освоения, разнообразием средств и возможностей совершения свободных социально ориентированных проб и необходимостью выстраивать в этом процессе особые, творческие взаимоотношения с окружающими людьми. Выбор, осмысление и освоение таких практик посредством совершения свободных проб обоснованы в проведенном исследовании как психолого-педагогические механизмы полагания и реализации субъектом его индивидуальных образовательных результатов. С этих позиций проявления субъектности учащихся в процессе дополнительного образования весьма разнообразны, базируются на обретенном ранее уровне образовательной самостоятельности, а также отражают выбираемый ими уровень социальных притязаний, реализуемых посредством достигаемых образовательных результатов. Крайне важен возрастной аспект этих проявлений, по- 
скольку деятельность проектирования индивидуальных образовательных результатов имманентна ведущей деятельности развития ребенка на каждом возрастном этапе.

Не менее важно и то, что особые формы проявления субъектности характерны для участвующих в этом процессе педагогов дополнительного образования. Их субъектность проявляется в первую очередь в готовности осуществлять с учащимися субъект-субъектные взаимодействия, не сводимые к традиционным формам обучения и трансляции готовых знаний.

В этой связи обоснован тезис о том, что такие специфические и развитые формы проявления субъектности участников образовательного процесса в наибольшей степени характерны для неформальной образовательной среды, чем и объясняется соответствие разработанной модели особым психолого-педагогическим и организационно-управленческим условиям учреждений дополнительного образования детей. В этих условиях индивидуальная образовательная траектория учащегося может проходить через различные свободно выбираемые им творческие объединения, что определяет открытость этой траектории разнообразным образовательным событиям и творческим проектам.

Полученные результаты теоретического исследования положены в основание нормативной модели проектирования индивидуальных образовательных результатов учащихся как технологии, реализуемой в условиях индивидуализации процесса дополнительного образования. Особенностью этой технологии выступает целевая направленность на развитие учащегося как субъекта проектирования собственных образовательных результатов, а также этапность, позволяющая воспроизводить во взаимодействии участников образовательного процесса об- 
щую логику и структуру социального проекта, устремленного в «потребное будущее». На этой же основе определены подходы и способы оценки и мониторинга индивидуальных образовательных результатов учащихся в системе дополнительного образования.

Таковы, в целом, результаты проведенного исследования, получившие отражение в настоящем издании. Они адресованы широкому кругу представителей образовательного сообщества и могут быть использованы в целях проектирования индивидуализированных образовательных систем, базирующихся на принципах неформальности образовательных сред и субъект-субъектных взаимодействий педагогов и учащихся. 


\section{СПИСОК ИСПОЛЬЗОВАННОЙ ЛИТЕРАТУРЫ}

1. Абляева Е.А. Мониторинг образовательных результатов: из опыта управленческой деятельности // Актуальные вопросы теории и практики управления. Сборник научных статей / под общей редакцией А.M. Чернопятова. Пермь, 2018. С. 6-11.

2. Александрова Е.А. Система педагогического сопровождения индивидуальной образовательной траектории // Продуктивное образование: проекты в продуктивном образовании. М., 2005. С. 12-21

3. Андрюкова И.В. Индивидуальный прогресс учащихся как объект оценки образовательных результатов // Человек и образование. 2013. № 2 (35). С. 117 - 121., с. 117 - 118.

4. Антонова А.М. Субъект-субъектное взаимодействие в образовательном процессе колледжа как условие организации учебно-исследовательской деятельности учащегося // Научные проблемы гуманитарных исследований. 2011. № 9. С. 137-144., с. 139-140.

5. Асмолов А.Г. Дополнительное образование как зона ближайшего развития образования России: от традиционной педагогики - к педагогике развития / // Внешкольник. 1997. № 9. С. 6-8.

6. Асмолов А.Г., Пастернак Н.А. Ребенок в культуре взрослых. М.: Издательство Юрайт, 2019. 150 с.

7. Асмолов А.Г. Дополнительное образование как зона ближайшего развития в России: от традиционной педагогики к педагогике развития // Стенограмма межрегионального совещания-семинара по проблеме «Повышение уровня управления развитием дополнительного образования детей. Петрозаводск, 13-15 марта 1996 г. С. 4-13.

8. Асташова Н.А. Концептуальные основы диалогической педагогики // Психолого-педагогический поиск. 2018. № 3(47). С. 15-28. 
9. Бганцева И.В. Учащийся как субъект инновационного процесса // Проектирование ситуации развития личности - основа современных образовательных технологий: научно-практическая конференция: тезисы докладов и сообщений. М., 2001. С. 173-176.

10. Бедерханова В.П., Бондарев П.Б.,. Педагогическое проектирование в инновационной деятельности. Краснодар: Просвещение-Юг, 2000. 54 с.

11. Библер В.С. Михаил Михайлович Бахтин, или Поэтика культуры. М. : Гнозис, 1991. 176 с.

12. Библер В.С. От наукоучения к логике культуры: два философских введения в двадцать первый век. М., 1990. 413 c.

13. Богоявленская Д.Б. Рабочая концепция одарённости // Вопросы образования. 2004. № 2. С. 46-68.

14. Божович Л.И. Личность и ее формирование в детском возрасте. СПб.: Питер, 2008. 398с.

15. Борытко Н.M. Мониторинг формирования личностных результатов ФГОСа как механизм управления образовательным процессом // Известия Волгоградского государственного педагогического университета. 2017. №1 (114). С. 21-29.

16. Бронникова Л.М. Субъект-субъектное взаимодействие учащегося и учителя в процессе формирования компетенции самообразования при обучении математике // Вестник Барнаульского государственного педагогического университета. 2008. № 8-3. С. 151152., с. 151.

17. Брушлинский А.В. Субъект: мышление, учение, воображение. М.; Воронеж, 1996. 392 с.

18. Бурляева О.В., Миронова М.П. Внутривузовский независимый мониторинг образовательных результатов студентов как ориентир совершенствования профессиональной подготовки педагога // Гуманитарные науки и образование. 2016. № 4 (28). С. 20-25. 
19. Гализова В.В. Принцип индивидуализации как основной принцип при переходе от дошкольного образования к начальному обучению // Педагогика и психология в контексте современных исследований проблем развития личности сборник материалов 3-й международной научно-практической конференции. 2013. С. 34-40

20. Гильмидинова Т.В. Педагогическое сопровождение инновационной деятельности педагогов в учреждении дополнительного образования детей: дисс. ... канд. пед. наук. Краснодар, 2015. 198 с.

21. Голованова Н.Ф. Социализация и воспитание ребенка. Спб.: Речь 2004. 272 с.

22. Гребенникова В.М., Игнатович В.К., Игнатович С.С. Принцип событийности в организации социокультурных практик учащихся как проектных единиц их индивидуальных образовательных маршрутов // Историческая и социально-образовательная мысль: научный журнал. 2015. Т. 7. № 5. Ч. 1. С. 207-213.

23. Гуденко А.В., Либерцова Е.В., Габучева Ю.П. Мониторинг образовательных достижений: персонифицированный электронный инструментарий оценки предметных и метапредметных результатов обучающихся // Качество образования в Евразии. 2018. № 6. С. 19-35.

24. Гуслякова Н.И., Садыкова Т.В. К вопросу об индивидуализации в дополнительном образовании детей // Молодой ученый. 2015. № 9 (89). C. 1047 - 1050. URL. https://moluch.ru/archive/89/17658/(Дата обращения 14.03.2019).

25. Демина Л.С. Особенности организации профессиональных проб при подготовке социальных педагогов в вузе Вестник Томского государственного педагогического университета. 2015. № 3 (156). С. 136-140. 
26. Денисова И.Ю. Одаренные учащиеся 3-4 классов как субъекты учебной деятельности // Педагогика и психология как ресурс развития современного общества: проблемы сетевого взаимодействия в инклюзивном образовании Материалы VII Международной научно-практической конференции, посвященной 100-летию РГУ имени С.А. Есенина. отв. ред. Л.А. Байкова, Н.А. Фомина, А.Н. Сухов. Рязань: Ряз. гос. ун-т имени С.А. Есенина. 2015. С. 24-26.

27. Дидактика средней школы. Некоторые проблемы соврем. дидактики: учеб. пособие для студентов пед. ин-тов / под ред. М.А. Данилова и М.Н. Скаткина. М.: Просвещение, 1975. 303 с.

28. Дьюи Д. Демократия и образование. М.: ПедагогикаПресс, 2000. 384 с,

29. Елистратов С.А. Мониторинг как средство управления качеством образовательных результатов // Сибирский научный вестник. 2016. № 1 (23). С. 46-50.

30. Зинченко В.П. Психологические основы педагогики. (Психолого-педагогические основы построения системы развивающего обучения Д.Б. Эльконина - В.В. Давыдова): учеб. пособие. М.: Гардарики, 2002. 431 с.

31. Иванова И.В., Логинова Л.Г. Мониторинг саморазвития обучающихся в контексте индивидуализации образовательного процесса в дополнительном образовании // Конференциум АСОУ: сборник научных трудов и материалов научно-практических конференций. 2015. № 1. С. 1412 - 1419. URL. https://elibrary.ru/download/elibrary_24357605_2947 2939.pdf. (Дата обращения 14.03.2019).

32. Игнатович В.К., Игнатович С.С., Гребенникова В.М., Бондарев П.Б. Проектирование индивидуального образовательного маршрута: проблема готовности субъекта: монография. М.: Ритм, 2015. 144 с. 
33. Игнатович В.К., Игнатович С.С. Образовательная самостоятельность старшеклассников и возможности ее оценки в режиме совместного пробного действия // Образовательное пространство России XXI века: материалы Всероссийской научно-практической очной онлайн-конференции с международным участием (г. Краснодар, 10 ноября 2017 г.). Краснодар: НОЧУ ДПО «Краснодарский многопрофильный институт дополнительного образования», 2017. С. 39-47.

34. Игнатович В.К., Гребенникова В.М. Образовательная самостоятельность как условие профессиональноличностного самоопределения старшеклассника // Историческая и социально-образовательная мысль. 2016. Т. 8. № 5. Ч. 2. С. 174-179.

35. Игнатович В.К., Игнатович С.С. Понятие индивидуальных образовательных результатов учащихся в контексте индивидуализации процесса дополнительного образования детей // Педагогика: вчера, сегодня, завтра. 2019. Т. 2. №2. С. 4 - 15.

36. Ионина Н.Г. Профессиональные пробы как форма организации профориентационной работы в школе // Биология в школе. 2013. № 9. С. 73-77.

37. Калинина Л.В., Аверченко А.В. Социальная проба как средство формирования гражданской идентичности младших школьников // Азимут научных исследований: педагогика и психология. 2017. Т. 6. № 1 (18). С. 332-335., с. 334.

38. Кисляков П.А. Экопсихология образовательной среды: подходы к проектированию и мониторингу // Экология человека. 2017. № 4. С. 42-50., с. 44.

39. Ковалева Т.М. Новые ресурсы дидактики для современной школы // Наука и школа. 2015. № 1. С. 88-94.

40. Ковалева Т.М. О тьюторской деятельности в современном высшем образовании // Тьюторство в открытом образовательном пространстве высшей 
школы: Материалы Всероссийской научнопрактической конференции. М., АПКиППРО, 2008. С. $5-14$

41. Ковалева Т.М. Принцип индивидуализации и профессия тьютора в российском образовании // Исторические истоки и теоретические основы тьюторства. Владивосток, 2014. С. 43-72.

42. Ковалева Т.М., Якубовская Т.В. Тьюторская деятельность как антропопрактика: между индивидуальной образовательной траекторией и индивидуальной образовательной программой // Человек.RU. 2017. № 12. C. 85-94. URL:

https://elibrary.ru/download/elibrary_27810510_3491 8038.pdf

43. Ковалева Т.М. Проводник в потоке возможностей (о тьюторстве в современном российском образовании) // Минская школа сегодня. 2013. № 9. С. 36 - 41.

44. Коджаспирова Г.М., Коджаспиров А.Ю. Словарь по педагогике. М.: ИКЦ «Март»; Ростов н/Д: Издательский центр «МарТ», 2005. 448 с., с. 289.

45. Колесникова И.А. Педагогическая праксеология: учеб. пособие для студ. высш. пед. учеб заведений / И.А. Колесникова, Е.В. Титова. М.: Издательский центр «Академия», 2005. 256 с.

46. Колесникова И.А., Горчакова-Сибирская М.П. Педагогическое проектирование: учеб. пособие для высш. учеб. заведений. М: Издательский центр «Академия», 2005. 288 с.

47. Концепция подростковой школы / под науч. ред. Б.Д. Эльконина, А.Б. Воронцова. М., 2003. URL.: http://www.ouro.ru/iro/exp/koncepciya/ 20.02.2015.

48. Корепанова И.А. Зона ближайшего развития как проблема современной психологии // Психологическая наука и образование. 2002. № 1. С. 42-50. 
49. Корнетов Г.Б. Что такое преобразующая педагогика // Психолого-педагогический поиск. 2018. № 4(48). С. $13-25$.

50. Коротаева Е.В. К истории становления категории «педагогическое взаимодействие//понятийный аппарат педагогики и образования: сб. науч. тр. Вып. 5 / отв. ред. Е.В. Ткаченко, М.А. Галагузова. М., 2007.

51. Крылова Н.Б. Культурные практики // Новые ценности образования. Антропологический, деятельностный и культурологический подходы: тезаурус / под. ред. Н.Б. Крыловой. 2005. № 5(24).

52. Кудрявцев В.Т. Развитое детство и развивающее образование: культурно-исторический подход. Ч. 1. Современное детство и инновации в дошкольном образовании. Дубна: ИЦ семьи и детства РАО, 1997. 174 с.

53. Кудрявцев В.Т. «Третий глаз» культуры (культурноисторический подход к воображению) // Педагогика способностей. К 70-летию О.М. Дьяченко. Материалы Всероссийского научно-практического семинара. 2018. С. 5-10.

54. Кудрявцев В.Т. Тропинки. Концептуальные основы проекта развивающего дошкольного образования. М.: Вентана-Граф, 2007. 144 с.

55. Кудрявцев В.Т., Хорчева М.И. Воображение, социальная ситуация развития и школьная готовность // Детский сад: теория и практика. 2017. № 5. С. 18-37.

56. Лабунская Н.А. Индивидуальный образовательный маршрут студента: подходы к раскрытию // Известия Российского гос. пед. ун-та им. А.И. Герцена. СПб., 2002. № 2 (3). С. 79-90.

57. Лактионова Е.Б. Личностное развитие учащегося как субъекта психологической экспертизы образовательной среды // Известия Российского государственного педагогического университета им. А.И. Герцена. 2013. № 155. С. 41-53. 
58. Леонтьев А.Н. Избранные психологические произведения: в 2 т. М.: Педагогика, 1983. Т. 1. 391 с.

59. Леонтьев Д.А. Психология смысла: природа, строение и динамика смысловой реальности. 2-е, испр. изд. М.: Смысл, 2003. 487 с.

60. Лукацкий М.А. О феномене инновационности и о том, куда нас ведет педагогическая инноватика // Психолого-педагогический поиск. 2019. № 3(51). С. 17-33., c. 23.

61. Макарова С.А. Формирование мотивационно ориентированной образовательной среды в учреждениях дополнительного образования: дисс. ... канд. пед наук Саранск, 2016.

62. Мамбеталина А.С. Дополнительное образование как важнейшая подсистема непрерывного образования // Педагогика: вчера, сегодня, завтра. 2018. Т. 1., № 2. С. 35-38.

63. Марасанов Г.И., Рототаева Н.А. Социальная компетентность: психологические условия развития в юношеском возрасте. М.: Когито-Центр, 2003. 172 с.

64. Митрофанова Л.М. Индивидуальный образовательный маршрут как механизм индивидуализации образовательного процесса в учреждении дополнительного образования детей // Известия Саратовского университета. 2012. Т. 12. Сер. Акмеология образования. Психология развития, вып. 4. С. 97-104., с. 98.

65. Михайлова В.Е. Возможности дополнительного образования детей в развитии способностей самоопределения у подростков и молодежи // Общество: социология, психология, педагогика. 2016. № 8. URL: http://dom-

hors.ru/rus/files/arhiv_zhurnala/spp/2016/8/pedagogi cs/mikhailova.pdf (дата выхода на сайте 30. 08. 2016).

66. Мищенко А.С., Клюшкин В.И. Учащиеся начальной и средней профессиональной школы как субъекты 
производительного труда и гражданского общества // Образ человека будущего: Кого и Как воспитывать в подрастающих поколениях: коллективная монография / под ред. О.А. Базалука. Киев, 2013.

67. Моисеев А.М. Стратегическое управление школой: словарь-справочник в трех томах / под ред. О.М. Моисеевой. Т. 2. М.: АСОУ, 2014. 384 с., 63.

68. Николина В.В. Социокультурная практика как вектор развития современного образовательного пространства // Научный диалог. 2017. № 2. С. 269-280.

69. Образовательная программа - маршрут ученика. Ч. 1 / под ред. А.П. Тряпицыной. СПб.: Изд-во «ЮИПК», 1998. $118 \mathrm{c}$.

70. Образовательная программа Федерального государственного бюджетного образовательного учреждения «Международный детский центр «Артек». URL: http://media.artek.org/media/uploads/svedeniya-obobr-org/obrazovanie/obrazovatelnaya-programmaarteka.pdf. (Дата обращения 31.10.2018)., с.15.

71. Овчинников О.В. Дистанционное образование как эффективная форма индивидуализации образования младших школьников // Гносеологические основы образования международный сборник научных трудов, посвященный профессору С.П. Баранову. Елец, 2015. С. 224-226

72. Остапенко А.А., Янковская Н.А. Переход в новую образовательную систему: готовность и маршрут (на примере перехода из начальной школы в основную) // Школьные технологии. 2014. № 1. С. 48-52.

73. Оценка качества образовательной деятельности школ и создание программ их развития / под ред. В.В. Серикова. М.: Сентябрь, 2004. 
74. Петровский В.А. Личность в психологии: парадигма субъектности: монография. Ростов-на-Дону; Феникс, 1996. $508 \mathrm{c}$.

75. Поливанова К.Н. Психологическое содержание подросткового возраста // Вопросы психологии. 1996. № 1. C. 20 - 34 .

76. Понукалин А.А. Системообразующая функция оценивания // Субъективная оценка в структуре деятельности: научно-тематический сборник. Саратов: Издво Саратовского ун-та, 1987. 144 с.

77. Попов А.А. Летний образовательный отдых детей в рамках компетентностного подхода: методическое пособие / Попов А.А., Глухов П.П., Луппа Г.М., Попова О.А. М.: ЛЕНАНД, 2016, 192 с.

78. Попов А.А. Образовательные программы и элективные курсы компетентностного подхода: научнометодическое пособие / сост. М.С. Аверков, С.В. Ермаков. [сайт] URL: https://e.mail.ru/attachment/15408146100000000821 /0;1 (дата обращения 29.10.2018).

79. Примерная основная образовательная программа дошкольного образования «Тропинки» / под ред. В.Т. Кудрявцева. М.: Вентана-Граф, 2014.

80. Программа дополнительного образования детей основной документ педагога: информационнометодический сборник. Вып. 5. СПб.: Ресурсный центр школьного дополнительного образования, 2010.

81. Пряжников Н.С. Профессиональное и личностное самоопределение. М.: Издательство "Институт практической психологии", Воронеж: НПО «МОДЭК», 1996. 256 c.

82. Радевская Н.С. Построение новых моделей образования взрослых в контексте индивидуализации и рас- 
ширения пространства образования // Человек и образование. 2017. № 1 (50). С. 26-29.

83. Розин В.М. Человек культурный. Введение в антропологию. М. - Воронеж: Издательство НПО «МОДЕК», 2003.

84. Савинова Н.А. Проектирование индивидуальных образовательных маршрутов учащихся на основе образовательных потребностей // Человек и образование. 2015. № 4 (45). С. 153 - 157. URL: https://elibrary.ru/download/elibrary_25953528_8618 0245.pdf (Дата обращения 28.10.2019)..

85. Самусева Г.В. Диагностика готовности учащихся к реализации позиции субъекта учебной деятельности // Перспективы науки и образования. 2013. № 1. С. 1422.

86. Сериков В.В. Обучение как вид педагогической деятельности: учеб. пособие для студ. высш. учеб. заведений / под ред. В.А. Сластенина, И.А. Колесниковой. М.: Издательский центр «Академия», 2008. 256 с., с. 226-227.

87. Симкина Е.А., Рудакова И.А. Сравнительный анализ требований к образовательному результату в ФГТ и ФГОС // Аспирант. 2015. Т. 1. № 8-1 (13). С. 9-11.

88. Собкин В.С., Калашникова Е.А. Подросток в системе дополнительного образования: социальнопсихологические аспекты // Психологопедагогический поиск. 2016. № 2(38). С. 43-68.

89. Собкин В.С., Калашникова Е.А., Лыкова Т.А. Индивидуализация образования: от дополнительного к начальному профессиональному // Практики развития: современный конфликт индивидуального и массового образования: материалы XXIII научнопрактической конференции. Красноярск, 2017. С. 7894. URL. 
https://elibrary.ru/download/elibrary_35008029_8116 4986.pdf., c. 92.

90. Тарасевич Г., Константинов А. Школа завтра не нужна // РР/ СЦЕНА: [электронный ресурс]. Режим доступа: http://rusrep.ru/article/2013/08/28/school/ (Дата обращения 12.10.2020).

91. Тубельский А.Н. Демократический уклад и экспертиза в образовании // Демократическая школа. 2005. № 2. С. 3-47

92. Федеральный закон от 29.12.2012 N 273-ФЗ (ред. от 03.08.2018) «Об образовании в РФ». http://www.consultant.ru/cons/cgi/online.cgi?req=doc \&base $=$ LAW\&n $=304167 \&$ fld $=134 \& d s t=1000000001,0 \& \mathrm{r}$ $\mathrm{nd}=0.570997319199457 \# 04251827391463683$

93. Федоров И.М. Переход от образовательной среды к образовательной экосистеме // Молодой ученый. 2019. № 28 (266). С. 246-250.

94. Фельдштейн Д.И. Психология развития личности в онтогенезе. М.: Педагогика, 1989. 208 с.

95. Философско-психологические проблемы развития образования / под ред. В.В. Давыдова; Российская Академия образования. М.: ИНТОР, 1994.128 с.

96. Цукерман Г.А. Взаимодействие взрослого и ребенка, творящее зону ближайшего развития // Культурноисторическая психология. 2006. № 4. С. 61-73.

97. Чурекова Т.М., Назимок В.Л. Самоопределение и самореализация личности учащегося в контексте субъект-субъектного взаимодействия // Самоопределение личности. Новые подходы и технологии: материалы II Международной научно-практической конференции, посвященной памяти профессора А.Д. Сазонова. М.,2005. С. 91-93.

98. Шаталов М.А. Об образовательных результатах процесса обучения в контексте требований нового Фе- 
дерального государственного образовательного стандарта // Международный журнал экспериментального образования. 2014. № 4-1. С. 271-274.

99. Шевелев А.Н. Индивидуализация в школьном образовании: неизбежность и возможности в контексте исторического опыта // Психолого-педагогический поиск. 2017. № 1(41). С. 28-39.

100. Шевелева Н.Н. Риски разработки индивидуальных образовательных траекторий обучающихся в образовательных организациях: взаимодействие участников образовательных отношений // Вестник PMAT. 2016. № 1. С. 121-125.

101. Школьная система оценки результатов и качества образования: от модели к технологии реализации. Кн. 4 / А.Б. Воронцов, Б.Д. Эльконин, В.М. Заславский, Е.В. Высоцкая, Е.В. Чудинова / под ред. А.И. Адамского. М., 2013. 286 с.

102. Щедровицкий Г.П. Избранные труды. Часть VII. Развитие. Учение. Игра. Игра и «детское общество» URL: http://gtmarket.ru/book/export/html/4001 (дата обращения 16.05.2018).

103. Щедровицкий П.Г. Образование как объект культурной политики // Образовательная политика. 2011. № 1 (51). С. 11-16.

104. Эльконин Б.Д. Действие как единица развития // Вопросы психологии. 2004. № 1. С. 35-49.

105. Эльконин Б.Д. Педагогика развития: пробное действие как основа образования: доклад на IX конференции «Педагогика развития (Красноярск, 2002). URL:

http://www.experiment.lv/rus/biblio/vestnik_11/v11_e lkonin.htm. (Дата обращения 22.04.2018). 
106. Эльконин Б.Д. Событие действия (Заметки о развитии предметных действий) // Культурноисторическая психология. 2014. № 1. С. 11-19.

107. Эльконин Д.Б. Избр. психол. труды. М.: Педагогика, 1989. $560 \mathrm{c}$.

108. Эльконин Б.Д. Эльконин Д.Б. Из научных дневников // Эльконин Д.Б. Избранные психологические труды. М., 1989., 519 c.

109. Эльконин Д.Б. Психическое развитие в детских возрастах // Избранные психологические труды. Издание 2-е, стереотипное / под ред. Д.И. Фельдштейна. М. - Воронеж, 1997. 416 с. 
1 Теоретико-методологические основания проблемы проектирования индивидуальных образовательных результатов учащихся в процессе дополнительного образования

1.1 Философские, культурно-исторические и практико-педагогические предпосылки проблемы проектирования индивидуальных образовательных результатов в системе дополнительного образования детей

1.2 Индивидуальный образовательный результат как объект исследования 21

1.3 Возрастные характеристики индивидуальных образовательных результатов учащихся 35

1.4 Особенности индивидуальных образовательных результатов учащихся в системе дополнительного образования Выводы по первой главе 69

2 Проектирование индивидуальных образовательных результатов как совместная деятельность учащихся и педагогов дополнительного образования 70

2.1 Современная практика полагания и оценки индивидуальных образовательных результатов учащихся 70

2.2 Проектирование индивидуальных образовательных результатов учащихся в процессе дополнительного образования 89

2.3 Учащийся как субъект проектирования индивидуальных образовательных результатов в процессе дополнительного образования 96 
2.4 Педагог дополнительного образования как субъект проектирования индивидуальных образовательных результатов ребенка 104 Выводы по второй главе 117

3 Методические и технологические аспекты проектирования индивидуальных образовательных результатов учащихся в системе дополнительного образования

3.1 Педагогические условия становления учащегося как субъекта полагания индивидуальных образовательных результатов....

3.2 Организация социальных проб учащихся учреждения дополнительного образования детей

3.3 Технология проектирования индивидуальных результатов учащихся в процессе дополнительного образования

3.4 Теоретические основания и методическая схема оценки индивидуальных образовательных результатов учащихся в процессе дополнительного образования

3.5 Мониторинг индивидуальных образовательных достижений учащихся как условие эффективности процесса дополнительного образования 165

\begin{tabular}{lr}
\multicolumn{1}{c}{ ВЫводЫ по третьей главе } & 178 \\
\hline ЗАКЛЮЧЕНИЕ & 180 \\
\hline СПИСОК ИСПОЛЬЗОВАННОЙ ЛИТЕРАТУРЫ & 184 \\
\hline
\end{tabular}


Научное издание

Игнатович В.К., Бондарев П.Б., Игнатович С.С., Курочкина В.Е.

ОСНОВЫ МЕТОДОЛОГИИ И ТЕХНОЛОГИЯ ПРОЕКТИРОВАНИЯ ИНДИВИДУАЛЬНЫХ ОБРАЗОВАТЕЛЬНЫХ РЕЗУЛЬТАТОВ УЧАЩИХСЯ В СИСТЕМЕ ДОПОЛНИТЕЛЬНОГО ОБРАЗОВАНИЯ ДЕТЕЙ

\author{
Монография
}

Подписано в печать 19.12.2020

Бумага типографская №1

Печать RISO. Усл. печ. л. 10,3. Тираж 500 экз.

Тираж изготовлен на полиграфической базе Кубанской многопрофильной Академии подготовки, переподготовки

и повышения квалификации специалистов г. Краснодар, мкр. Пашковский, ул. Заводская, 32/301 